\title{
American chestnut soil carbon and nitrogen dynamics: Implications for ecosystem response following restoration
}

\author{
Geoffrey W Schwaner
}

Follow this and additional works at: https://researchrepository.wvu.edu/etd

\footnotetext{
Recommended Citation

Schwaner, Geoffrey W, "American chestnut soil carbon and nitrogen dynamics: Implications for ecosystem response following restoration" (2018). Graduate Theses, Dissertations, and Problem Reports. 7248.

https://researchrepository.wvu.edu/etd/7248

This Thesis is protected by copyright and/or related rights. It has been brought to you by the The Research Repository @ WVU with permission from the rights-holder(s). You are free to use this Thesis in any way that is permitted by the copyright and related rights legislation that applies to your use. For other uses you must obtain permission from the rights-holder(s) directly, unless additional rights are indicated by a Creative Commons license in the record and/ or on the work itself. This Thesis has been accepted for inclusion in WVU Graduate Theses, Dissertations, and Problem Reports collection by an authorized administrator of The Research Repository @ WVU. For more information, please contact researchrepository@mail.wvu.edu.
} 
American chestnut soil carbon and nitrogen dynamics:

Implications for ecosystem response following restoration

\author{
Geoffrey W. Schwaner
}

Thesis submitted

to the Davis College of Agriculture, Natural Resources, and Design

at West Virginia University

in partial fulfillment of the requirements for the degree of

\author{
Master of Science in \\ Forestry \\ Charlene Kelly, Ph.D, Chair \\ William Peterjohn, Ph.D \\ Edward Brzostek, Ph.D \\ Department of Forest Resource Management
}

Morgantown, WV

2018

Keywords: American chestnut, soil, ecology, carbon, nitrogen Copyright 2018 Geoffrey W. Schwaner 


\title{
Abstract \\ American chestnut soil carbon and nitrogen dynamics: Implications for ecosystem response following restoration
}

\author{
Geoffrey W. Schwaner
}

The once dominant American chestnut tree (Castenea dentata) was essentially extirpated from the US eastern deciduous forest as a result of the infestation by the chestnut blightfungus (Cryphonectria parasitica) in the early 1900's, in what is considered the largest disturbance event since glaciation. However, back-cross breeding and transgenic approaches have resulted in the production of blight resistant trees, and the reintroduction of the American chestnut is considered imminent. In the event of a successful reintroduction, significant ecosystem changes in carbon (C) and nitrogen (N) cycling are expected but have yet to be understood or quantified. This thesis consists of two studies: (1) Measuring select ecosystem pools of $\mathrm{C}$ and $\mathrm{N}$ of chestnut and two commonly cooccurring species; (2) A laboratory-based soil incubation to evaluate select ecosystem fluxes of $\mathrm{C}$ and $\mathrm{N}$, such as litter decomposition and $\mathrm{C}$ and $\mathrm{N}$ mineralization, of chestnut and two commonly co-occurring species. The results of this study indicate chestnut accumulates biomass at a greater rate than Northern red oak (Quercus rubra) or black cherry (Prunus serotine), and soils from beneath chestnut retain more mineral nitrogen and contained more DOC in leachate in a soil and leaf litter incubation study. 


\section{Acknowledgements}

I was a common sight in many different labs throughout WVU's campus while working towards completing my research, and I am extraordinarily grateful for the wonderful sense of community here. I would like to thank my advisor, Dr. Charley Kelly, and the other members of my committee, Dr. Eddie Brzostek and Dr. William Peterjohn. I would like to thank also thank Dr. Timothy Driscoll, Dr. Richard Thomas and Dr. James McGraw of WVU's Department of Biology, Dr. Shika Sharma of WVU's department of Geology, and Dr. Zac Freedman and Dr. Ben Andoh of WVU's Davis College and their lab groups for the use of lab space and equipment, advice and guidance. I would also like to thank Dr. Douglass Jacobs and Brian Beheler of Purdue University for the use of the research plantation in Martell Experimental forest, and for assistance at the site. Funding for this project is provided by the USDA McIntire-Stennis award. 


\section{TABLE OF CONTENTS}

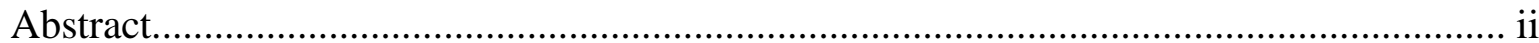

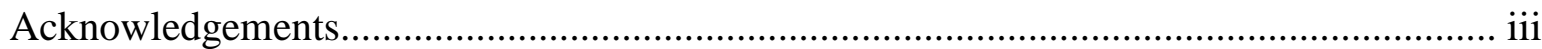

Table of Contents.................................................................................................. iv

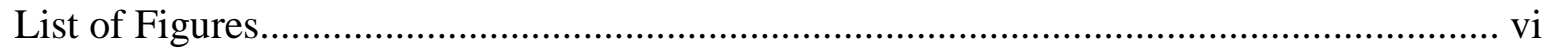

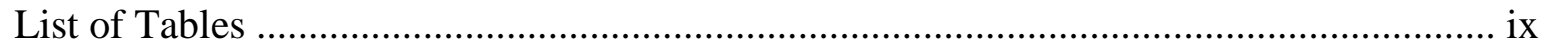

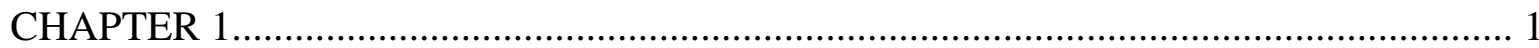

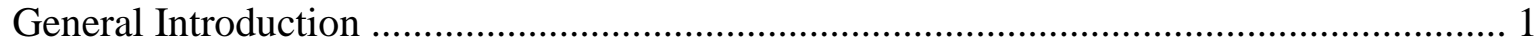

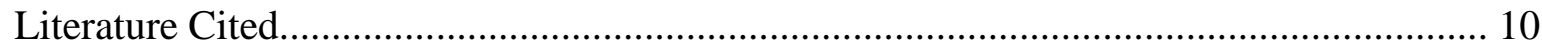

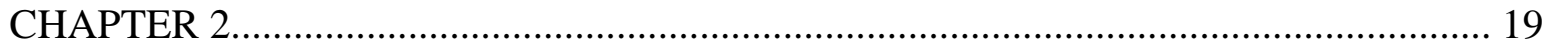

Comparing ecosystem pools of carbon and nitrogen of American chestnut and co-occurring

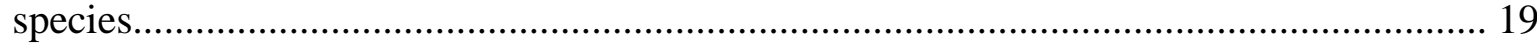

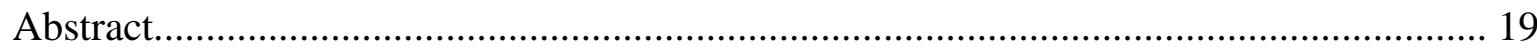

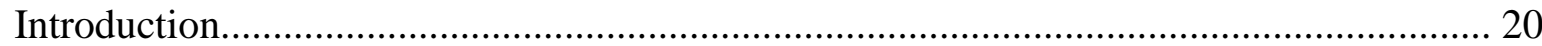

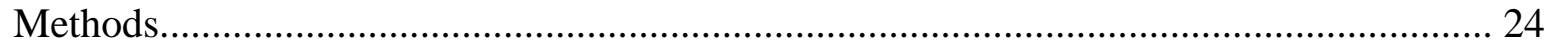

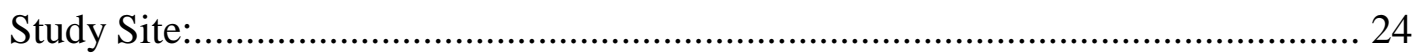

Litter and forest floor sampling:...................................................................... 25

Biomass and $\mathrm{C}$ content estimation:................................................................... 26

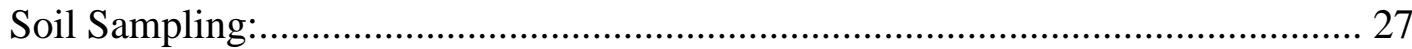

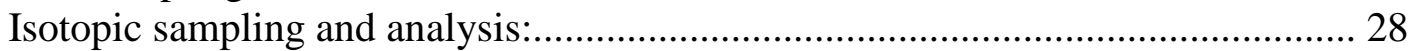

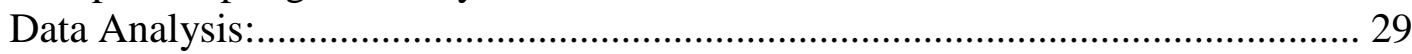

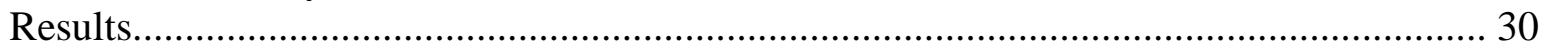

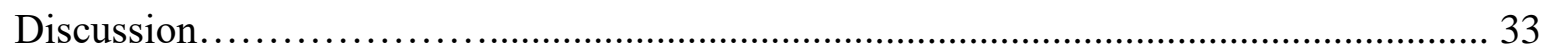

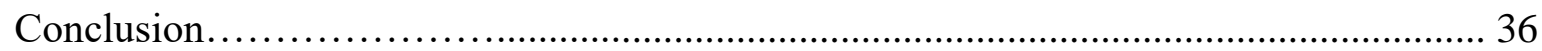

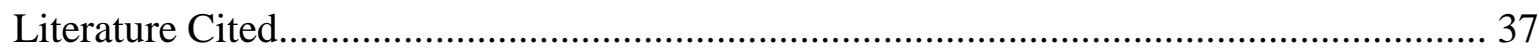

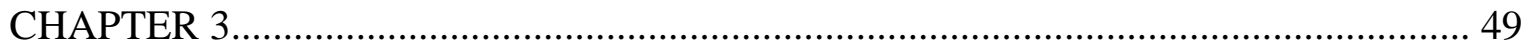

American chestnut mediates soil $\mathrm{C}$ and $\mathrm{N}$ dynamics in a laboratory incubation................. 49

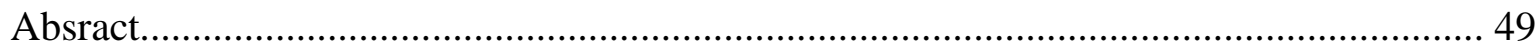

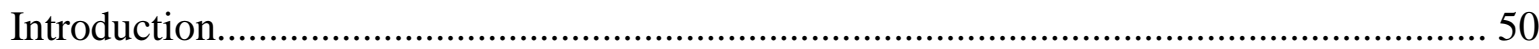

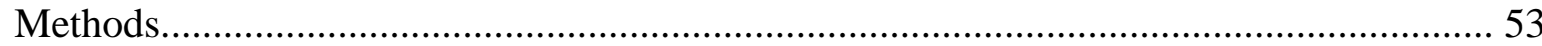

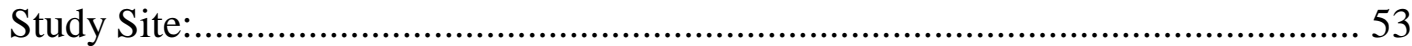

Incubation core construction and sampling:....................................................... 54

Repeated sample collection and measurements:.................................................. 55

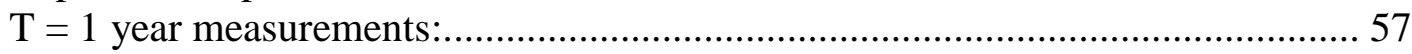

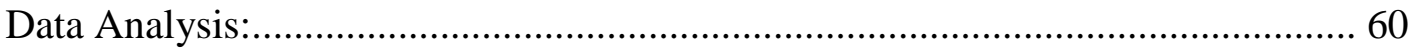




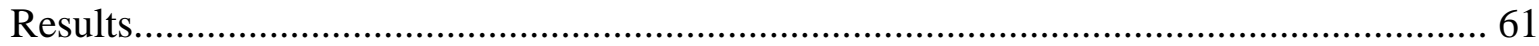

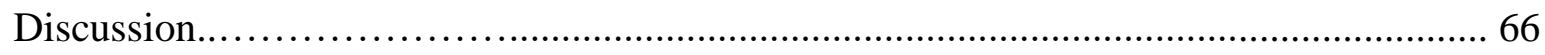

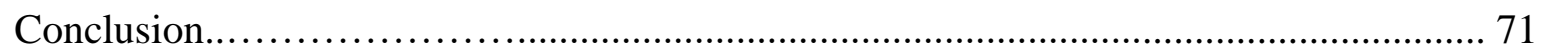

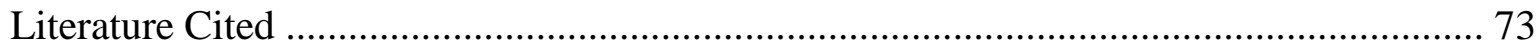




\section{LIST OF FIGURES}

Figure 1.1. The historical range of Castanea dentata within the eastern United States.... 14

Figure 1.2. The location of the Martell Research Forest, West Lafayette, Indiana 15

Figure 1.3. Aerial view of the study site in West Lafayette, IN. Block 1 is to the top left, Block 4 to the top right, Block 3 to the bottom right

Figure 1.4. Site map of the Martell forest study site. Plots are distinguished by species combination and spacing distance between trees. Small boxes indicate $1 \times 1 \mathrm{~m}$ spacing, medium are $2 \times 2 \mathrm{~m}$ plots and large are $3 \times 3 \mathrm{~m}$. 3x3 m plots, and 2 species mixes are excluded from study. Plots that have high mortality are shaded in.

Figure 1.5. Conceptual model of $\mathrm{C}$ cycling of cherry (AM), chestnut (ECM) and oak (ECM). Chestnut is predicted to have greater SOM storage than oak due to higher litter $\mathrm{C}: \mathrm{N}$ ratio, and much greater storage than cherry due to litter $\mathrm{C}: \mathrm{N}$ ratio and mycorrhizal association

Figure 2.1: Mean forest floor total mass (top left), C (top right) and N (bottom left) pools $(\mathrm{kg} / \mathrm{ha})$ of chestnut, cherry and red oak plots. Bars with different letters are significantly different by Tukey's HSD test. Error bars represent +/- 1 SE from the mean.................. 43

Figure 2.2: Mean total litter mass, (top left) C (top right) and $\mathrm{N}$ (bottom left) pools (kg/ha) of chestnut, cherry and red oak collected from 8/2016-6/2017. Bars with different letters are significantly different by Tukey's HSD test. Error bars represent +/- $1 \mathrm{SE}$ from the mean

Figure 2.3: Mean above-ground biomass (top), and biomass $C$ (bottom) of chestnut, cherry and red oak plots. Bars with different letters are significantly different by Tukey's HSD test. Error bars represent $+/-1 \mathrm{SE}$ from the mean.

Figure 2.4: Mean back-transformed mineral soil C (top), and mean mineral soil $\mathrm{N}$ (bottom) of chestnut, cherry and red oak plots. Error bars represent +/- 1 SE from the mean.

Figure 2.5: Mean total $C$ present in plots of chestnut, cherry and oak, comprised of biomass, litter, forest floor and the top $5 \mathrm{~cm}$ of mineral soil. Bars with different letters are significantly different by Tukey's HSD test. Error bars represent +/- 1 SE from the mean

Figure 2.6: Mean $\delta^{13} \mathrm{C}$ values of soil cores from $2 \mathrm{~m}$ chestnut, cherry and oak plots, along with cores collected from outside each plot in the field. Error bars represent +/- $1 \mathrm{SE}$ from the mean. 
Figure 3.1: Mean cumulative $C$ loss through respiration (+/- $1 \mathrm{SE})$ over $\mathrm{T}=10$ months of black cherry, American chestnut, and northern red oak.

Figure 3.2: Mean cumulative $\mathrm{N}(+/-1 \mathrm{SE})$ mineralized over $\mathrm{T}=10$ months of American chestnut, black cherry and northern red oak. Bars with different letters are significantly different by Tukey HSD test.

Figure 3.3: Mean cumulative DOC (+/- $1 \mathrm{SE})$ collected over $\mathrm{T}=10$ months of American chestnut, black cherry and northern red oak. Bars with different letters are significantly different by Tukey HSD test. ......................................................................... 82

Figure 3.4: Mean total POXC (+/- $1 \mathrm{SE})$ by species, spacing and block. Error bars represent $+/-1 \mathrm{SE}$ from the mean.

Figure 3.5: Mean enzyme activity ( $\mathrm{mmol} / \mathrm{h} / \mathrm{g})$ (+/- $1 \mathrm{SE}$ ) of AP (top left), PER (top right) and PPO (bottom left) for chestnut, black cherry and red oak. Bars with different letters are significantly different by Tukey HSD test. 84

Figure 3.6: Mean (+/- 1 SE) BG:NAG enzyme activity ratio of soils from chestnut, cherry and oak incubation cores. Bars with different letters are significantly different by Tukey HSD test.

Figure 3.7: Mean $\%$ mass loss at $\mathrm{T}=1$ year of litter taken from chestnut, cherry and oak incubation cores. Bars with different letters are significantly different by Tukey HSD test. Error bars represent +/- $1 \mathrm{SE}$ from the mean

Figure 3.8: Acid insoluble compound and soluble lignin concentration of composited ( $\mathrm{n}=2$ per species) fresh litter from before incubation, and decayed litter at $\mathrm{T}=1$ year from chestnut, oak and cherry incubation cores. Bars with different letters are significantly different by Tukey HSD test. Error bars represent +/- 1 SE from the mean.

Figure 3.9: Tannin concentration of composited ( $n=2$ per species) fresh litter from before incubation, and decayed litter at $\mathrm{T}=1$ year from chestnut, oak and cherry incubation cores. Bars with different letters are significantly different by Tukey HSD test. Error bars represent +/- $1 \mathrm{SE}$ from the mean 88

Figure 3.10: Correlations of $\%$ litter mass loss and litter $\%$ acid insoluble compound and soluble lignin (top left), \% tannin (top right), \% acid insoluble compound and soluble lignin loss (bottom left) and \% tannin loss (bottom right). Correlation coefficient and $\mathrm{p}$ value are reported in the top right of each individual graph. 89 
Figure 3.11: Correlations of $\mathrm{N}$ mineralized during incubation experiment and NAG enzyme activity (top left), \% litter mass loss (top right), DOC (bottom left) and \% tannin loss (bottom right). Correlation coefficient and $\mathrm{p}$ value are reported in the top right of each individual graph. 90

Figure 3.12: PCA of leaf litter chemistry variables, including species separation (top) and linear regression of litter decomposition against litter chemistry PC 1 (bottom)................ 91 


\section{List of Tables}

Table 2.1: $\% \mathrm{C}, \% \mathrm{~N}$ and $\mathrm{C}: \mathrm{N}$ ratio of chestnut, cherry and oak foliage, leaf litter and forest floor material. Values within a category that have different letter in parenthesis are significantly separate from one another by Tukey HSD test.

Table 2.2: Allometric equations for calculating biomass from $\mathrm{DBH}, \mathrm{R}^{2}$ of allometric equations, and \% $\mathrm{C}$ of bole for American chestnut, black cherry and northern red oak...... 42

Table 3.1: Significance factors of model effects and interactions for enzyme activity and ratios from soils collected from plots of chestnut, cherry and red oak and incubated for one year with leaf litter of their respective species.

Table 3.2: Eigenvalues of two PC of litter chemistry, soil chemistry, soil enzyme activity and all variables calculated using PCA, and significance of linear regression between PC's

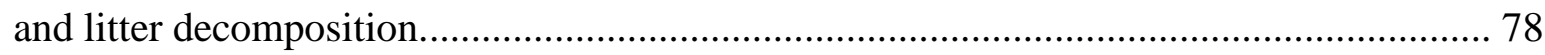


Chapter 1:

General Introduction 
American chestnut (Castanea dentata) was once a dominant tree species across much of the Appalachian Mountain region, with a historical range stretching from Alabama to Maine (Figure 1.1), and covering over $800,000 \mathrm{~km}^{2}$ (Braun 1950). The tree was highly valued for its wood, which is light, strong, rot-resistant, high in tannin content, straight-grained and easy to work with, and was used for construction, fence posts, poles, trim, furniture, firewood and in the leather tanning industry (Wang et al. 2013). At its peak use in the early 1900's, over 600 million board feet of chestnut timber was harvested, and comprised up to a quarter of hardwood lumber produced in New England, and 15-18 \% of the hardwood production in Appalachia (Youngs 2000). In addition, the mast crop of chestnuts was a reliable annual source of income for local economies, with prices as high as $\$ 5$ per bushel (Zon 1904). Chestnut was also an important food and habitat source for terrestrial wildlife, such as black bear, white-tailed deer and turkey, and aquatic leaf processing macroinvertebrates such as caddisfly larvae (Diamond et al. 2000; Smock and McGregor 1988; Carpenter et al. 1992).

American chestnut historically occupied well-drained, sandy, back-slope sites that today are dominated by the oak-hickory forest type (Wang et al. 2013). However, they are able to successfully grow in a variety of climates and site conditions, and are moderately drought tolerant (Abrams et al. 1990). Chestnut is at least intermediately shade-tolerant (Pinchot et al. 2017), and though seeds are prone to predation and insect damage, they are produced at a prolific rate (Wang et al. 2013). In addition, on good quality sites, chestnut is able to overtop and outcompete other hardwoods, such as oaks (Jacobs \& Severeid 2004) following disturbance. These characteristics allowed chestnut to propagate in great numbers throughout their range, with the canopy being up to $50 \%$ chestnut for forest stands within the Appalachian Mountains 
(Braun 1950). This high abundance, combined with chestnut's importance for wildlife, caused it to be labeled a "foundation species", influencing community structure and ecosystem processes wherever the species occurred (Youngs 2000; Ellison et al. 2005).

At the turn of the $20^{\text {th }}$ century, the parasitic fungus Cryphonectria parasitica, colloquially known as chestnut blight, caused the functional extinction of the American chestnut throughout the entire historic range. The blight originated from Asia, where it infected the Chinese chestnut (Castanea mollissima), a close relative of the American chestnut. Chinese chestnut has some natural resistance to this blight, but American chestnut does not, and the American trees quickly succumb to girdling due to cankers formed by the fungus. In addition to the chestnut blight, chestnuts are very susceptible to Phytophthera cinnamoni, or root rot, in moist or riparian soils (Russel 1987).

The first recorded instance of the chestnut blight in North America occurred in 1904 at the Bronx Zoological Park, located in New York City (Merkel 1905), and quickly spread throughout the chestnut's native range. The damage caused by the fungus was exacerbated by extensive salvage harvests initiated after early quarantine measures failed, further speeding chestnut's demise (Hepting 1974; Anagnostakis 1987). By 1960, an estimated 4 billion trees were killed due to the fungus and salvage harvests (Wang et al. 2013). While mature trees are now extremely rare, the species does still commonly exist as an understory component throughout its historical range, due to sprouts forming from chestnut's resilient root system (Russel 1987). However, due to the blight's continued existence, these sprouts are typically girdled and killed before reaching seed producing age, and represent much less total biomass than pre-blight populations (Paillet 1984). 
The loss of such an important species not only had economic and habitat impacts, but also likely altered ecosystem biogeochemical cycling. It is known that tree species differentially influence soil decomposition and mineralization rates through the chemical composition of leaf litter, root litter, and exudates, and are therefore capable of controlling forest nutrient cycling rates (Peterjohn et al. 1999; Phillips et al. 2013, Yin et al. 2014). As co-occurring species such as oak (Quercus spp.), hickory (Carya spp.) and sugar maple (Acer saccharum) became more prominent, processes such as decomposition, carbon (C) and nitrogen (N) cycling, and forest productivity, which were once strongly influenced by chestnut, were likely altered on a large scale throughout Appalachia (Ellison et al. 2005).

Due to the economic and habitat value of chestnut, there is great public support for attempting to bring the species back as a canopy tree. There are currently several approaches to instilling blight resistance in American chestnut, including backcross breeding with Chinese trees (Jacobs 2007, Hebard 2006), the introduction of hypovirulent blight strains (MacDonald \& Fulbright, 1991), and genetic engineering techniques to introduce genes providing resistance (Barakat et al. 2009). Due to the success of these programs, the reintroduction of the American chestnut has been considered imminent (Jacobs 2007). More recently, three stands of the latest generation of back-cross bred chestnut seedlings planted in 2009 in Virginia, Tennessee, and North Carolina are currently being evaluated on growth, blight resistance and 4-year survival compared to pure American and Chinese trees (Clark et al. 2015). These sites are similar to proposed sites for a USDA Forest Service chestnut introduction effort to plant chestnut stands within national forests planned for when the blight resistance of the back-cross trees is confirmed and the seedlings are 
readily available (Clark et al. 2014). Due to chestnut's ability to exist on a wide range of site conditions and high competitiveness during stand regeneration (McEwan et al. 2006), it is forecast that it will readily spread and once again become a dominant species in the Appalachian hardwood forests over the course of the next century.

Given the functional loss of chestnut throughout its native range, relatively little is known about its ecological characteristics and influence on biogeochemical cycling. It is known that chestnut trees are associated with ectomycorrhizal (ECM) fungi (Jacobs et al. 2013), which generally have poorer quality litter when compared to trees with arbuscular mycorrhizal (AM) associations. There are competing models of how AM vs ECM associations affect C storage below ground. One predicts that ECM trees generally result in greater below-ground C storage when compared to AM species due to poorer quality litter reducing available $\mathrm{N}$ for microbial uptake which in turn reduces demand for C (Averill et al. 2014; Taylor et al. 2016; Vesterdal et al. 2013). The competing model predicts that AM litter, with greater $\mathrm{N}$ concentrations will be more rapidly processed by microbes, leaving highly processed and stable $\mathrm{C}$ compounds (Craig et al. 2018). For this study, it was hypothesized that the species at the Martell site would follow the Taylor et al. framework of ECM species having greater $\mathrm{C}$ storage belowground compared to the AM species.

However, previous studies have shown chestnut litter may have lower $\mathrm{C}: \mathrm{N}$ ratios than other ECM species, such as the oaks and hickories that have replaced them (Ellison et al. 2005, Smock and McGregor, 1988), and may also contain greater concentrations of other nutrients, such as phosphorus and calcium compared to mixed hardwood litter (Rhodes, 2006). Conversely, other 
studies have reported no differences in $\mathrm{C}: \mathrm{N}$ ratio between chestnut and other ECM litter, and show that chestnut litter may also contain high concentrations of tannins, lignin, and other recalcitrant compounds, which may act to slow decomposition and nitrogen mineralization (Rosenberg 2010). This lack of consensus on decomposition and mineralization rates means potential ecosystem changes in the event of successful reintroduction of chestnut to its native range are poorly understood.

Conceptually, $\mathrm{C}$ and $\mathrm{N}$ exist within a forested ecosystem as living biomass, leaf litter, decayed forest floor matter, and soil organic matter (SOM). To understand potential changes to eastern hardwood forests in the event of a successful chestnut reintroduction, I determined the size of select pools of $\mathrm{C}$ and $\mathrm{N}$ currently present in 10-year-old plantation stands of American chestnut and two commonly co-occurring tree species (Chapter 2 of this thesis). In this study, I collected soil, leaf litter, and forest floor material from plots of the three species present at a study site located within Purdue University’s Martell Research Forest, West Lafayette, Indiana, USA (Figure 1.2). At this site, plots of pure, non-hybrid American chestnut, two other commonly cooccurring species, northern red oak (Quercus rubra) and black cherry (Prunus serotina), and 3way mixes of each species, were planted in 2007 to study chestnut growth (Gauthier et al, 2013) (Figure 1.3, Figure 1.4). Prior to plantation conversion, the site was under cultivation for corn. Above-ground biomass (AGB) for each species was also estimated and converted into $\mathrm{C}$ and $\mathrm{N}$ pools using allometric equations. I hypothesized that chestnut (ECM) would have:

1. Greater pools of AGB compared to oak (ECM) and cherry (AM). due to more rapid growth. 
2. Greater pools of leaf litter and forest floor $\mathrm{C}$ compared to both oak and cherry due to chestnut litter containing higher C:N ratios and high tannin content (Figure 1.5).

One of the major reasons for studying nutrient cycling changes is to understand the potential impacts on soil C sequestration. Globally, more $\mathrm{C}$ is stored within soil than in biomass and the atmosphere combined (Davidson \& Janssens 2006), and is an important part of global climate models. For the final component of my thesis, I investigated differences in carbon sequestration pathways (retention vs. accumulation) between chestnut, oak, and cherry (Chapter 2 of this thesis) using the natural ${ }^{13} \mathrm{C}$ isotopic signature created by corn that had previously been grown at the study site. Corn, as a $\mathrm{C}_{4}$ photosynthetic plant, typically has a more enriched $\delta^{13} \mathrm{C}$ signature in SOM derived from it when compared to $\mathrm{C}_{3}$ plants, such as the trees in this study. Soil cores were collected from each study plot, and from outside the plots in the managed field where they were planted, and analyzed for $\delta^{13} \mathrm{C}$, along with foliage and leaf litter from each species. Utilizing a simple 2-point mixing equation and comparing the inputs to the $\delta^{13} \mathrm{C}$ value of soil outside the plots, the relative proportion of $\mathrm{C}$ within the SOM pool from corn and each tree species could be determined (Resh et al. 2002). Using stable ${ }^{13} \mathrm{C}$ isotope techniques, I tracked the loss of the old soil organic $\mathrm{C}$ from the previous $\mathrm{C}_{4}$ land use and the gain of new soil organic $\mathrm{C}$ from the $\mathrm{C}_{3}$ trees to better understand accumulation of new $\mathrm{C}$ relative to decomposition of older C. A lower $\delta^{13} \mathrm{C}$ value within the soil below one tree species compared to another would indicate that it has accumulated more $\mathrm{C}$ below-ground from tree biomass inputs. I hypothesized that chestnut would have a lower $\delta^{13} \mathrm{C}$ value, and therefore greater belowground $\mathrm{C}$ storage due to its lower quality litter and high tannin concentrations limiting $\mathrm{N}$ availability and slowing decomposition. 
A second important aspect of quantifying changes in nutrient cycling are the fluxes of $\mathrm{C}$ and $\mathrm{N}$ between pools (Chapter 3 of this thesis). To examine select ecosystem fluxes, I utilized a laboratory soil incubation experiment to determine fluxes of soil respiration $\left(\mathrm{CO}_{2}\right), \mathrm{N}$ mineralization, and litter decomposition mass loss $(k)$ rates. For the study, soil was collected from each plot of chestnut, oak, and cherry from the Martell Forest and placed within a PVC pipe core. A known mass of leaf litter from each corresponding plot was placed atop the soil. The cores were kept at room temperature for one year, and were watered to field capacity once per week. Every two weeks, soil respiration was measured in lab using a Li-Cor 8100A field respiration chamber to estimate $\mathrm{C}$ loss through $\mathrm{CO}_{2}$ production. Once per month, $75 \mathrm{~mL}$ of Hoagland rainwater nutrient solution, modified to remove any form of $\mathrm{N}$, were added to the cores after watering to field capacity, and leachate was collected and subsequently analyzed for potential loss of $\mathrm{C}$ and $\mathrm{N}$ through dissolved organic carbon (DOC) and mineral $\mathrm{N}$. Upon completion of the incubation, the leaf litter was removed and weighed to determine decomposition rate, and the soil was analyzed for enzyme activity, bulk $\mathrm{C}$ and $\mathrm{N}$, and oxidizable C available for uptake. I hypothesized that chestnut (relative to oak and cherry) would have:

1) Slower litter decomposition rates,

2) Lower $\mathrm{N}$ mineralization, and

3) Lower enzyme activity when compared to oak and cherry due to high concentrations of tannins in the leaf litter, which may bind proteins and enzymes.

I further hypothesized that the lower litter decomposition and $\mathrm{N}$ mineralization rates would reduce the amount of available $\mathrm{N}$ to microbes in soil, causing $\mathrm{N}$ limitation, limiting microbial energy and reducing $\mathrm{C}$ uptake and respiration rates, and thus increase the amount of DOC available in leachate and $\mathrm{C}$ in soil (Figure 1.5). 
The results of these studies within this thesis may have important implications for how forest biogeochemical cycling may be altered after a successful reintroduction of American chestnut. For example, if chestnut does reduce decomposition and $\mathrm{N}$ mineralization rates, it could reduce the amount of available $\mathrm{N}$ for tree uptake, which could have implications for forest productivity (Magil et al. 2000) and $\mathrm{N}$ export to streams draining forested watersheds (Peterjohn et al. 2015). In addition, changes in SOM accumulation and AGB could have implications for the total amount of $\mathrm{C}$ stored within the Appalachian region. Previous studies have documented up to an 80 metric ton ha ${ }^{-1}$ difference in total C in soil and biomass between hardwood species (Jandl et al. 2007). If even a much more modest difference of 5 metric ton ha ${ }^{-1}$ exists between chestnut and the species that have replaced it, this would still represent millions of tons of $\mathrm{C}$ in the event of successful reintroduction. Because there is strong public support for this species reintroduction, and scientific support suggesting that reintroduction of this foundation species is possible, it is critical to understand how ecosystem processes may be altered. 


\section{Literature Cited}

Abrams, M. D., Schultz, J. C., \& Kleiner, K. W. (1990). Ecophysiological responses in mesic versus xeric hardwood species to an early-season drought in central Pennsylvania. Forest Science, 36(4), 970-981.

Anagnostakis, S. L. (1987). Chestnut blight: the classical problem of an introduced pathogen. Mycologia, 79(1), 23-37.

Averill C, Turner BL, Finzi AC. 2014. Mycorrhiza-mediated competition between plants and decomposers drives soil carbon storage. Nature 505: 543-545.

Barakat, A.; DiLoreta, D.S.; Yi Zhang, C.S. [and others]. 2009. Comparison of the transcriptomes of American chestnut (Castanea dentata) and Chinese chestnut (Castanea mollissima) in response to the chestnut blight infection. BMC Plant Biology. 9: 51.

Bauerle, W. L., Wang, G. G., Bowden, J. D., \& Hong, C. M. (2006). An analysis of ecophysiological responses to drought in American Chestnut. Annals of Forest Science, 63(8), 833-842.

Braun, E. L. (1950). Deciduous forests of eastern North America. Deciduous forests of Eastern North America.

Carpenter, S. R., Fisher, S. G., Grimm, N. B., \& Kitchell, J. F. (1992). Global change and freshwater ecosystems. Annual Review of Ecology and Systematics, 119-139.

Clark, S. L., Schlarbaum, S. E., Pinchot, C. C., Anagnostakis, S. L., Saunders, M. R., ThomasVan Gundy, M., ... \& Casey, D. M. (2014). Reintroduction of American chestnut in the national forest system. Journal of Forestry, 112(5), 502-512.

Clark S. L., Schlarbaum S. E., Saxton A. M., Hebard F. V. (2015) Establishment of American chestnuts (Castanea dentata) bred for blight (Cryphonectria parasitica) resistance: influence of breeding and nursery grading. New Forests 47: 243-270

Craig, M. E., Turner, B. L., Liang, C., Clay, K., Johnson, D. J., \& Phillips, R. P. (2018). Tree mycorrhizal type predicts within-site variability in the storage and distribution of soil organic matter. Global change biology.

Davidson, E. A., \& Janssens, I. A. (2006). Temperature sensitivity of soil carbon decomposition and feedbacks to climate change. Nature, 440(7081), 165-173.

Diamond, S. J., Giles, R. H., Kirkpatrick, R. L., \& Griffin, G. J. (2000). Hard mast production before and after the chestnut blight. Southern Journal of Applied Forestry, 24(4), 196-201. 
Drake, J. E., Darby, B. A., Giasson, M. A., Kramer, M. A., Phillips, R. P., \& Finzi, A. C. (2012). Stoichiometry constrains microbial response to root exudation-insights from a model and a field experiment in a temperate forest. Biogeosciences, 10(2), 821.

Ellison, A. M., Bank, M. S., Clinton, B. D., Colburn, E. A., Elliott, K., Ford, C. R., ... \& Mohan, J. (2005). Loss of foundation species: consequences for the structure and dynamics of forested ecosystems. Frontiers in Ecology and the Environment, 3(9), 479-486.

Gauthier, M., Zellers,K., E, Löf, M, Jacobs, D., F. (2013). Inter- and intra-specific competitiveness of plantation-grown American chestnut (Castanea dentata). Forest Ecology and Management, 291, 289-299

Hebard, F. V. (2006). The backcross breeding program of the American chestnut foundation. Journal of the American Chestnut Foundation, 19, 55-77.

Hepting, G. H. (1974). Death of the American chestnut. Journal of Forest History, 18(3), 61-67.

Jacobs, D. F. (2007). Toward development of silvical strategies for forest restoration of American chestnut (Castanea dentata) using blight-resistant hybrids. Biological Conservation, 137(4), 497-506.

Jacobs, D. F., Dalgleish, H. J., \& Nelson, C. D. (2013). A conceptual framework for restoration of threatened plants: the effective model of American chestnut (Castanea dentata) reintroduction. New Phytologist, 197(2), 378-393.

Jacobs, D.F.; Severeid, L.R. 2004. Dominance of interplanted American chestnut (Castanea dentata) in southwestern Wisconsin, USA. Forest Ecology and Management. 191: 111-120.

Jandl, R., Lindner, M., Vesterdal, L., Bauwens, B., Baritz, R., Hagedorn, F., ... \& Byrne, K. A. (2007). How strongly can forest management influence soil carbon sequestration?. Geoderma, 137(3), 253-268.

Lin, G., McCormack, M. L., Ma, C. and Guo, D. (2017), Similar below-ground carbon cycling dynamics but contrasting modes of nitrogen cycling between arbuscular mycorrhizal and ectomycorrhizal forests. New Phytol, 213: 1440-1451.

MacDonald, W. L., \& Fulbright, D. W. (1991). Biological control of chestnut blight: use and limitations of transmissible hypovirulence. Plant Dis, 75(7), 656-661.

Magill, A. H., Aber, J. D., Berntson, G. M., McDowell, W. H., Nadelhoffer, K. J., Melillo, J. M., \& Steudler, P. (2000). Long-term nitrogen additions and nitrogen saturation in two temperate forests. Ecosystems, 3(3), 238-253.

Magill, A. H., Aber, J. D., Berntson, G. M., McDowell, W. H., Nadelhoffer, K. J., Melillo, J. M., \& Steudler, P. (2000). Long-term nitrogen additions and nitrogen saturation in two temperate forests. Ecosystems, 3(3), 238-253. 
McEwan, R. W., Keiffer, C. H., \& McCarthy, B. C. (2006). Dendroecology of American chestnut in a disjunct stand of oak chestnut forest. Canadian Journal of Forest Research, $36(1), 1-11$.

Merkel, H. W. 1905. A deadly fungus on the American chestnut. 10th Annual Report. NY Zoological Society: 97-103.

Paillet, F.L. 1984. Growth form and ecology of American chestnut [Castanea dentata] sprout clones in northeastern Massachusetts. Bulletin. Torrey Botanical Club. 111:316-328.

Peterjohn, W. T., Foster, C. J., Christ, M. J., \& Adams, M. B. (1999). Patterns of nitrogen availability within a forested watershed exhibiting symptoms of nitrogen saturation. Forest Ecology and Management, 119(1), 247-257.

Peterjohn, W. T., Harlacher, M. A., Christ, M. J., \& Adams, M. B. (2015). Testing associations between tree species and nitrate availability: Do consistent patterns exist across spatial scales?. Forest Ecology and Management, 358, 335-343.

Phillips, R. P., Brzostek, E., \& Midgley, M. G. (2013). The mycorrhizal-associated nutrient economy: a new framework for predicting carbon-nutrient couplings in temperate forests. New Phytologist, 199(1), 41-51.

Pinchot, C. C., Schlarbaum, S. E., Clark, S. L., Saxton, A. M., Sharp, A. M., Schweitzer, C. J., \& Hebard, F. V. (2017). Growth, survival, and competitive ability of chestnut (Castanea Mill.) seedlings planted across a gradient of light levels. New Forests, 1-22.

Resh, S. C., Binkley, D., \& Parrotta, J. A. (2002). Greater soil carbon sequestration under nitrogen-fixing trees compared with Eucalyptus species. Ecosystems, 5(3), 217-231.

Rhoades, C. C. (2007). The influence of American Chestnut (Castanea dentata) on nitrogen availability, organic matter and chemistry of silty and sandy loam soils. Pedobiologia, 50(6), 553-562.

Rosenberg, C. (2010). Foliar Chemical Analysis, Decomposition, and Effects on Nutrient Cycling of American Chestnut and its Hybrids (MS Thesis). Retrieved from https://etd.ohiolink.edu/rws_etd/document/get/ohiou1276875529/inline

Russell, E.W.B. 1987. Pre-blight distribution of Castanea dentata (Marsh.) Borkh. Bulletin. Torrey Botanical Club. 114: 183-190.

Smock, L. A., \& MacGregor, C. M. (1988). Impact of the American chestnut blight on aquatic shredding macroinvertebrates. Journal of the North American Benthological Society, 212-221.

Taylor, M. K., Lankau, R. A., \& Wurzburger, N. (2016). Mycorrhizal associations of trees have different indirect effects on organic matter decomposition. Journal of Ecology, 104(6), 15761584 . 
Vesterdal L, Clarke N, Sigurdsson BD, Gundersen P. 2013. Do tree species influence soil carbon stocks in temperate and boreal forests? Forest Ecology and Management 309: 4-18.

Wang, G. G., Knapp, B. O., Clark, S. L., \& Mudder, B. T. (2013). The Silvics of Castanea dentata (Marsh.) Borkh. American Chestnut, Fagaceae (Beech Family). US Forest Service, Southern Research Station. General Technical Report SRS-173.

Yin, H., Wheeler, E., Phillips, R. P. (2014). Root-induced changes in nutrient cycling in forests depend on exudation rates. Soil Biology \& Biochemistry, 78, 213-221.

Youngs, R. L. (2000). "A Right Smart Little Jolt": Loss of the Chestnut and a Way of Life. Journal of Forestry, 98(2), 17-21.

Zon, R. 1904. Chestnut in southern Maryland. Bureau of Forestry Bulletin 53. Washington, DC: U.S. Department of Agriculture. 31 p. 


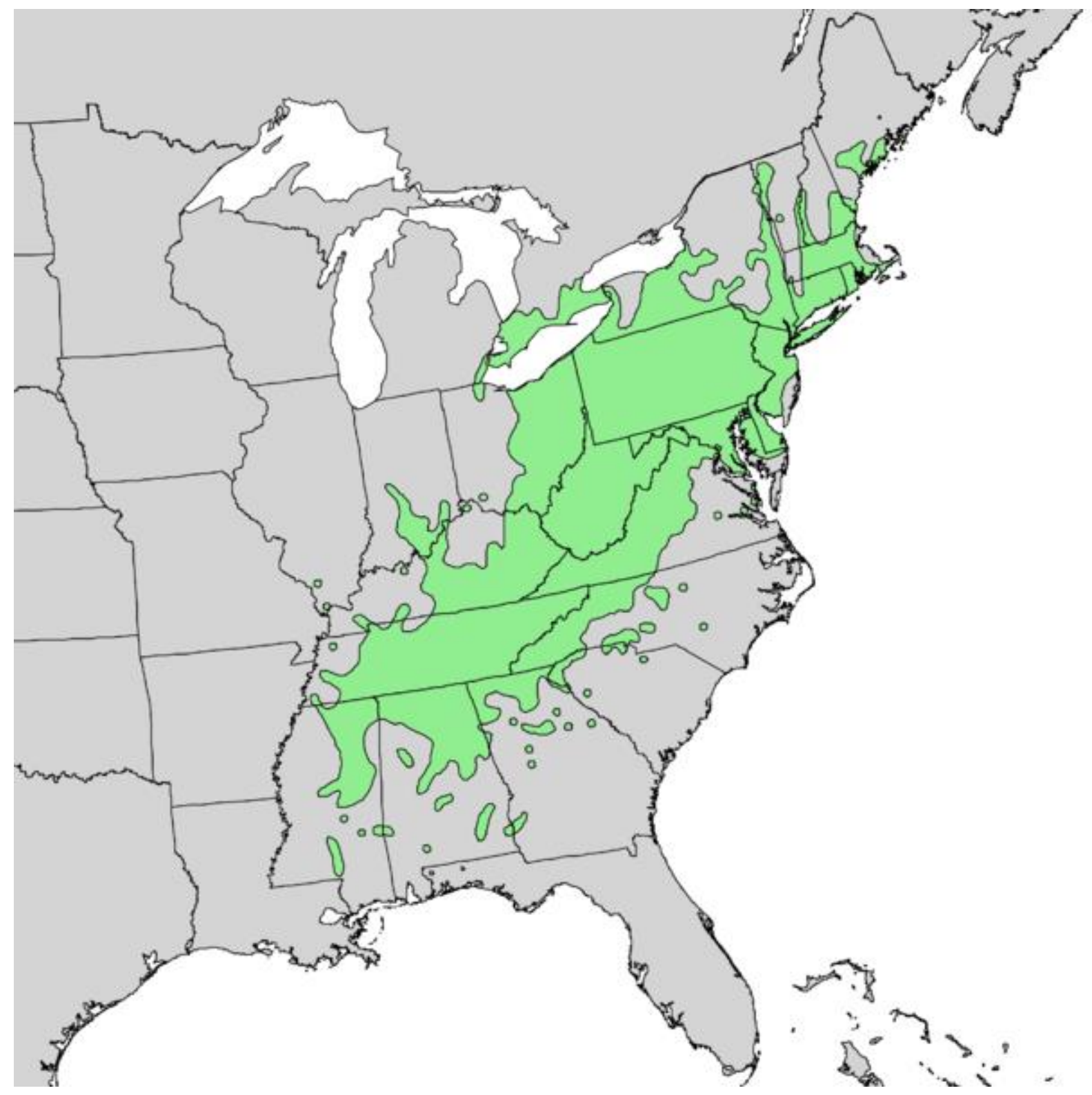

Figure 1.1: The historical range of Castanea dentata within the eastern United States. 


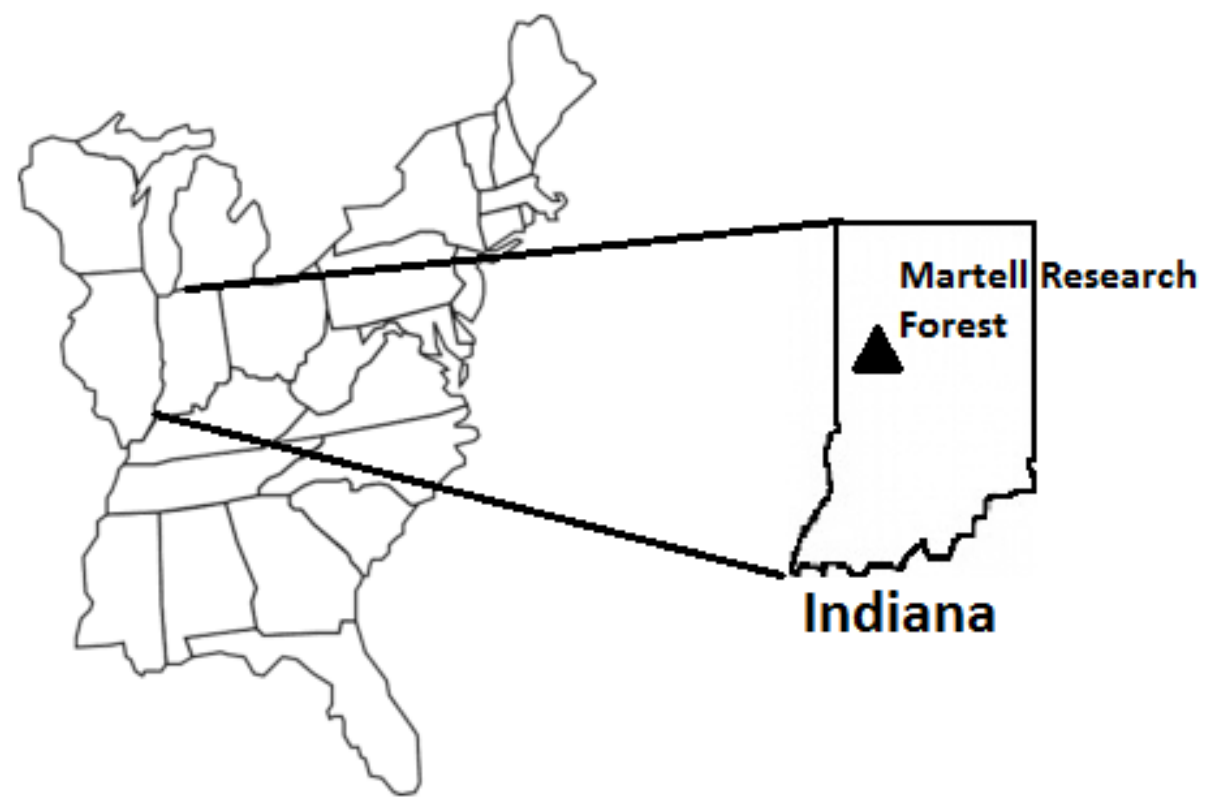

Figure 1.2: The location of the Martell Research Forest, West Lafayette, Indiana. 


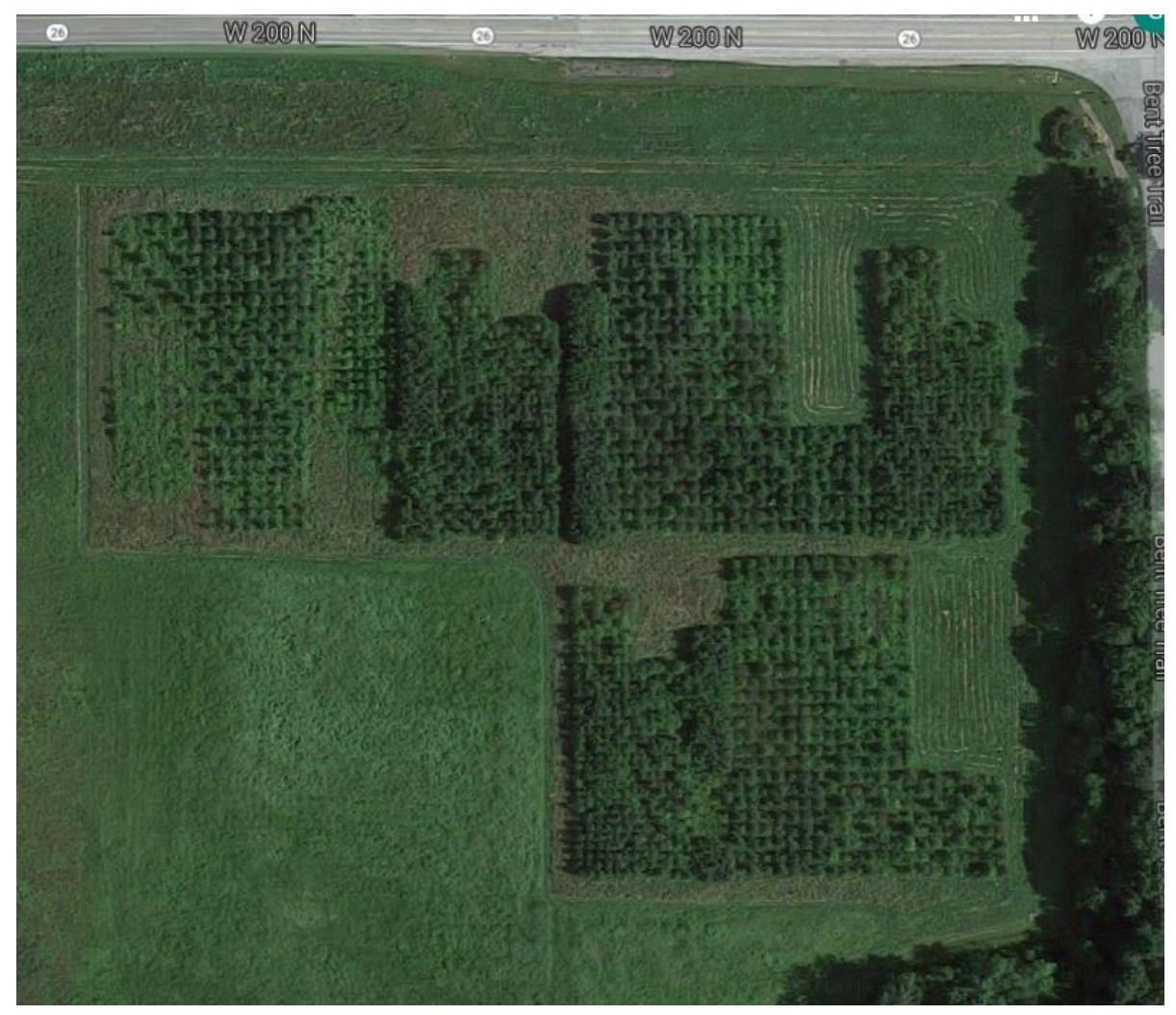

Figure 1.3: Aerial view of the study site in West Lafayette, IN. Block 1 is to the top left, Block 4 to the top right, Block 3 to the bottom right. 


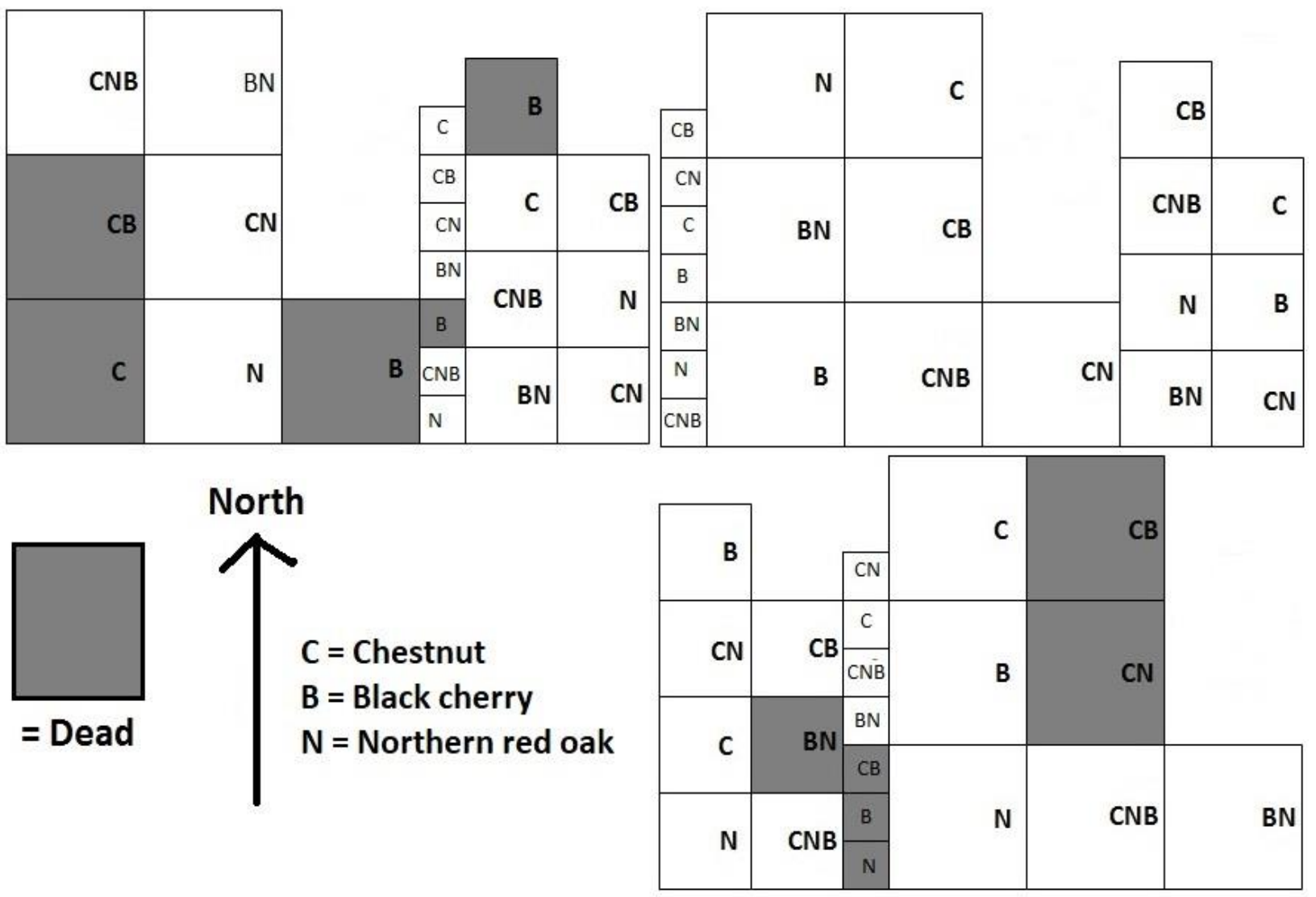

Figure 1.4: Site map of the Martell forest study site. Plots are distinguished by species combination and spacing distance between trees. Small boxes indicate $1 \times 1 \mathrm{~m}$ spacing, medium are $2 \times 2 \mathrm{~m}$ plots and large are $3 \times 3 \mathrm{~m} .3 \times 3 \mathrm{~m}$ plots, and 2 species mixes are excluded from study. Plots that have high mortality are shaded in. 


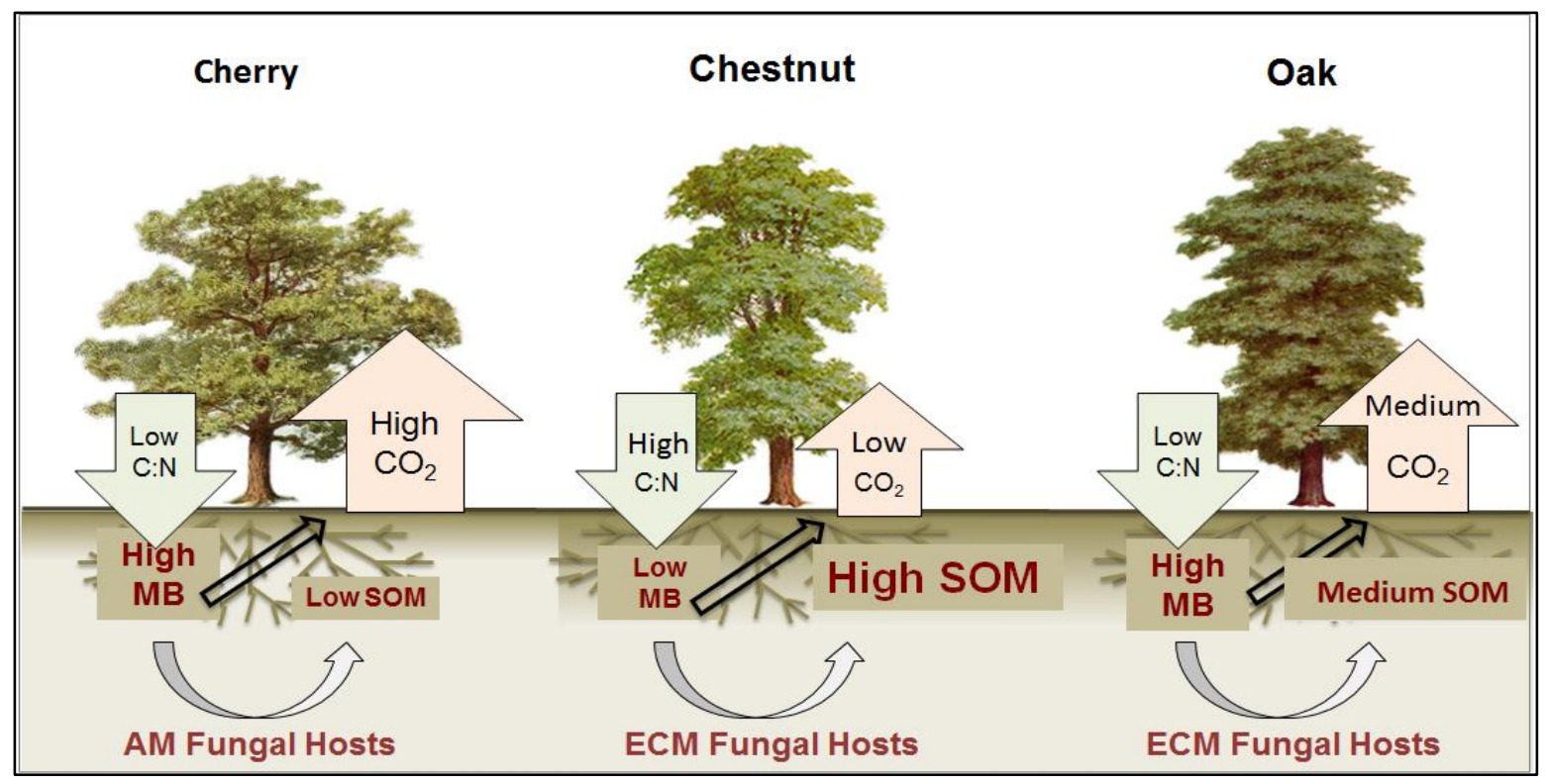

Figure 1.5: Conceptual model of $C$ cycling of cherry (AM), chestnut (ECM) and oak (ECM). Chestnut is predicted to have greater SOM storage than oak due to higher litter C:N ratio, and much greater storage than cherry due to litter $\mathrm{C}: \mathrm{N}$ ratio and mycorrhizal association. 


\title{
Chapter 2:
}

\section{Comparing ecosystem pools and fluxes of carbon and nitrogen of American chestnut and}

\author{
co-occurring species
}

\begin{abstract}
In forested ecosystems, pool size of carbon $(\mathrm{C})$ and nitrogen $(\mathrm{N})$ within soil and biomass, as well as biogeochemical fluxes of $\mathrm{C}$ and $\mathrm{N}$, can vary greatly between species as a function of plant inputs to the soil. At the turn of the $20^{\text {th }}$ century, American chestnut (Castenea dentata), a previously dominant and widespread canopy species in the eastern deciduous forest, was extirpated from its native range by chestnut blight fungus, an introduced species from Asia. Through development of blight-resistant trees, the reintroduction of American chestnut to its native range is considered imminent. However, relatively little is known about the biogeochemistry of forests influenced by chestnut. In this study, ecosystem pools of $\mathrm{C}$ and $\mathrm{N}$ in organic and mineral soils and above-ground biomass, along with fluxes of leaf litter are measured in plots of American chestnut and two historically commonly co-occurring species, northern red oak (Quercus rubra) and black cherry (Prunus serotina) in a plantation in Martell Research Forest, West Lafayette, Indiana, USA. An isotopic analysis of ${ }^{13} \mathrm{C}$ was also performed to assess soil $\mathrm{C}$ accumulation as influenced by the three tree species. Key findings from this study indicate chestnut has greater above-ground biomass and biomass $C\left(86,695 \mathrm{~kg} \mathrm{ha}^{-1} ; 40,349\right.$ $\left.\mathrm{kg} \mathrm{C} \mathrm{ha}{ }^{-1}\right)$ compared to cherry $\left(33,921 \mathrm{~kg} \mathrm{ha}^{-1} ; 16,801 \mathrm{~kg} \mathrm{C} \mathrm{ha}^{-1}\right)$, and a trend in greater biomass and biomass $\mathrm{C}$ compared to oak $\left(58,346 \mathrm{~kg} \mathrm{ha}^{-1} ; 27,141 \mathrm{~kg} \mathrm{C} \mathrm{ha}^{-1}\right)$ in these 10 year-old planted stands. In addition, the organic soil $\mathrm{N}$ pools in chestnut plots were smaller than oak (chestnut organic soil $=72.84 \mathrm{~kg} \mathrm{~N} \mathrm{ha}^{-1}$; oak organic soil $=123.3 \mathrm{~kg} \mathrm{~N} \mathrm{ha}^{-1}$ ). These results indicate chestnut may reduce forest $\mathrm{N}$ pools upon reintroduction, and may be of use for forest managers for $\mathrm{C}$ sequestration in biomass.
\end{abstract}




\section{Introduction:}

The two largest pools of terrestrial carbon are soil organic matter (SOM) and above-ground biomass (AGB). It is understood that SOM is controlled not only by soil type and climate, but also by the functional group and species of plants interacting with the soil (Van Cleve \& Powers 1995; Finzi et al. 1998; Jobbágy \& Jackson 2000). Forested ecosystems sequester greater amounts of atmospheric carbon dioxide $\left(\mathrm{CO}_{2}\right)$ into stable SOM and AGB than other ecosystem types, such as grasslands, storing up to two thirds of terrestrial C (Brown et al. 1993), though particular tree species promote $\mathrm{C}$ storage to differing extents. This sink of $\mathrm{C}$ is believed to offset up to $~ 3.1 \mathrm{Pg}$ of the of $\sim 9.3 \mathrm{Pg}$ of $\mathrm{C}$ added to the atmosphere per year due to fossil fuel emissions (Bellassen \& Luyssaert, 2014; Quéré et al. 2016; Budget, 2016). This knowledge has led to a greater awareness of how land-use change, forest management practices, or shifts in dominant tree species can mitigate or exacerbate rising atmospheric $\mathrm{CO}_{2}$ concentrations (Canadell \& Raupach, 2008).

Tree species can often differentially influence belowground nutrient cycling. Belowground nutrient cycling can be inflenced by differences in chemical composition of leaf litter, root litter and exudates, and mycorrhizal association (Yin et al. 2014; Lin et al. 2017. These characteristics influence the amount of stable soil C, N availability, and microbial community and activity, which in turn affects forest productivity (Peterjohn et al. 1999; Magill et al. 2000; Phillips et al. 2013). These controls of nutrient cycling, specifically N, are thought to play a large role in the C budget of an ecosystem (Resh et al. 2002; Phillips et al. 2013). Because of this, different tree 
species can be associated with divergent rates of ecosystem $\mathrm{N}$ cycling and loss (Lovett et al. 2002; Lin et al. 2017) and storage of C, both above- and below-ground (Finzi et al. 1998; Schulp et al. 2008). The differences in $\mathrm{C}$ stocks can range from minimal to up to an 80 ton ha ${ }^{-1}$ difference in total $\mathrm{C}$ in soil and biomass between hardwood species (Jandl et al. 2007). In a study at the Canaan Mountain Plateau in Connecticut, US, red oak stands were reported to contain $9.4 \mathrm{~kg} \mathrm{C} \mathrm{m}^{-2}$ within the surface $15 \mathrm{~cm}$ of mineral soil, signifying a $16 \%$ greater $\mathrm{C}$ storage compared to sugar maple (Acer saccharum) stands (Finzi et al. 1998).

Previous research has hypothesized that important forest biogeochemical shifts likely occurred throughout the historic range of chestnut following its decline due to chestnut blight (Cryphonectria parasitica) at the turn of the $20^{\text {th }}$ century (Ellison et al. 2005). This may have influenced standing pools of $\mathrm{C}$ and $\mathrm{N}$ within both soil and standing biomass, although the magnitude and direction of changes are unknown. However, it is known that American chestnut trees are associated with ectomycorrhizal (ECM) fungi (Jacobs et al. 2013), and trees with ECM associations generally have poorer quality litter (e.g. high C:N, high lignin:N) and slower belowground nutrient cycling when compared to trees with arbuscular mycorrhizal (AM) associations and ECM associations generally result in greater below-ground C storage when compared to AM species (Averill et al. 2014; Vesterdal et al. 2013). Despite this, very little is known regarding the influence that American chestnut has on ecosystem $\mathrm{C}$ and $\mathrm{N}$ cycling relative to commonly co-occurring tree species or species that chestnut may replace, especially in below-ground pools. 
Historical data and more recent silvicultural studies of newly-bred blight resistant ChineseAmerican chestnut hybrids, have indicated that chestnut displays rapid growth at young ages, and can outcompete and overtop other historically co-occurring species (Jacobs \& Severeid 2004), and retain higher total biomass as they age (Jacobs et al. 2009). In addition, historical and modern data on chestnut silvics indicate it is a generalist species, able to grow on a variety of sites, is a prolific seed producer, and is thought that it will rapidly propagate throughout its former historical range upon successful reintroduction (Abrams et al. 1990; Wang et al. 2013; Pinchot et al. 2017). Because of this, chestnut may be a suitable species to be used by forest managers to promote greater $\mathrm{C}$ sequestration into both SOM and biomass in the future (Jacobs et al. 2009).

One method of approximating the amount of SOM inputs to the soil from different species is to utilize the difference in $\delta^{13} \mathrm{C}$ due to land use change from $\mathrm{C}_{4}$ photosynthetic agriculture to $\mathrm{C}_{3}$ forest plantations (Resh et al. 2002). Fractionation of ${ }^{12} \mathrm{C}$ versus ${ }^{13} \mathrm{C}$ isotopes occurs during photosynthesis due to plants preferentially using lighter ${ }^{12} \mathrm{C}$ when available (O'Leary 1988). In $\mathrm{C}_{3}$ photosynthesis, fractionation occurs as $\mathrm{CO}_{2}$ diffuses into stomates, dissolves into cell cytoplasm and diffuses into chloroplasts, and during carboxylation by ribulose. Carboxylation is typically the rate limiting step in the process, and ${ }^{12} \mathrm{C}$ will subsequently be able to diffuse back out of the chloroplasts at a greater rate than the heavier ${ }^{13} \mathrm{C}$. In addition, carboxylation is irreversible, and highly discriminatory in favor of ${ }^{12} \mathrm{C}$ (Bender 1971). However, plants utilizing the $\mathrm{C}_{4}$ method of photosynthesis, such as corn, do not have the same carboxylation step during the photosynthetic process. Instead, $\mathrm{CO}_{2}$ is catalyzed by phosphoenolpyruvate carboxylase, which is less discriminatory. The resulting $\mathrm{C}$ acids are transported to bundle sheath cells, and 
converted back into $\mathrm{CO}_{2}$ in the presence of ribulose where it cannot diffuse out, and as a result have a more enriched $\delta^{13} \mathrm{C}$ signature compared to $\mathrm{C}_{3}$ plants (Bender 1971, Marshal et al. 2007).

It is therefore possible to estimate the relative amount of new, $\mathrm{C}_{3}$ tree-derived SOC sequestered into soil that was formerly dominated by $\mathrm{C}_{4}$ photosynthesis by utilizing a simple two-point mixing model, and measuring the $\delta^{13} \mathrm{C}$ values of the new $\mathrm{C}_{3}$ inputs and the old $\mathrm{C}_{4}$ derived SOM (Resh et al. 2002). A tree species that affects greater SOM storage would result in a more depleted $\delta^{13} \mathrm{C}$ signature, as more of the total SOM would be $\mathrm{C}_{3}$-derived. In particular, this technique may be useful for determining the potential change in $\mathrm{C}$ storage below ground in the future, as the plantation was only 10 years old at the time of analysis, while meaningful changes in total soil C may take decades to develop.

In this study, I determined the size of select pools and fluxes of $\mathrm{C}$ and $\mathrm{N}$ currently present in 10year-old plantation stands of American chestnut and two commonly co-occurring tree species and utilized isotopic analyses to determine the change in below-ground total $\mathrm{C}$ since conversion. At this site, plots of pure, non-hybrid American chestnut and two other commonly co-occurring species, northern red oak (Quercus rubra) and black cherry (Prunus serotina) were planted in 2007 to study chestnut growth (Gauthier et al. 2013) (Figure 1.3, Figure 1.4). I hypothesized that chestnut would have larger pools of mineral soil and forest floor $\mathrm{C}$ due to slow decomposition rates resulting from relatively poor quality, high C:N litter compared to oak, and because of chestnut's ECM association compared to the AM association of cherry (hypothesis 1). In addition, I hypothesized that chestnut would have smaller fluxes of $\mathrm{N}$ entering forest floor and mineral soil pools from leaf litter inputs, resulting in less $\mathrm{N}$ within the mineral soil and forest 
floor of chestnut plots compared to oak and cherry plots due to low concentrations of $\mathrm{N}$ within chestnut litter (hypothesis 2). I also hypothesized that chestnut would have larger AGB C pools than oak or cherry due to relatively faster growth rates. Lastly, I hypothesized that chestnut would have a more depleted soil $\delta^{13} \mathrm{C}$ value than cherry or oak, due to chestnut litter material containing less $\mathrm{N}$ and greater concentrations of recalcitrant compounds, causing an accumulation of $\mathrm{C}_{3}$-derived SOM (hypothesis 3).

\section{Methods}

Study site:

The soil, litter, forest floor samples, and biomass measurements were collected at Purdue University’s Martell Research Forest in West Lafayette, Indiana, USA (40 $26^{\circ} 422^{\prime N}$, $\left.87^{\circ} 01^{\prime} 47^{\prime} \mathrm{W}\right)$. A 2.4 ha plantation of pure, non-hybrid American chestnut, along with two other commonly co-occurring species (Northern red oak, Quercus rubra, and Black cherry, Prunus serotina) were planted in 2007 to study chestnut growth (Gauthier et al, 2013). Prior to tree planting in 2007, the field was cultivated with corn. The plantation consists of seven mixtures of species, randomized within three tree spacing regimes. Each plot contains 25 trees in a $5 \times 5$ tree square. Plots selected to be included in this study were monocultures of one of three different species:

1) Black cherry,

2) American chestnut,

3) Northern red oak 
In addition to the plots included in this study, there are other plots containing species mixtures containing $50 \%$ of 2 species, and a three-way mix of each species, but were excluded.

The tree spacing regimes included in this study consisted of the $1 \times 1 \mathrm{~m}\left(10,000\right.$ stems ha $^{-1}, 5 \times 5$ $\mathrm{m}$ plot size $)$ and $2 \times 2 \mathrm{~m}\left(2,500 \mathrm{stems} \mathrm{ha}^{-1}, 10 \times 10 \mathrm{~m}\right.$ plot size $)$ spacing. This is replicated 3 on site ( 3 species monocultures, 2 densities, 3 replicates; $n=6 ; \mathrm{N}=18$ ). In addition to the two stem densities included in the study, there is also an additional 3x3 meter stem density for each species combination, but was excluded due to high tree mortality rates within this spacing regime. The field around the plots is mowed, but the understory within the plots is unmanaged, allowing for deposition and accumulation of litter material to the forest floor.

Soils at the site are of the Rockfield series, which are mildly acidic to almost neutral and consist mainly of silt loams with a clay content of approximately 20-32\% (NRCS, accessed 2018). They are typically moderately productive, deep, and formed from silty outwash and loamy till. Soil profiles were characterized at all three blocks and did not vary significantly, showing a $2-5 \mathrm{~cm}$ agriculturally disturbed Ap-horizon, and limited Bt-horizon development. There is no Oa horizon of highly decomposed organic matter, but lightly decomposed litter forming an Oi horizon and moderately decomposed organic matter in an Oe horizon are present. From 19812010, mean annual temperature was $10.4^{0} \mathrm{C}$, and mean annual precipitation was $970 \mathrm{~mm}$ at the plantation location (National Climatic Data Center, 2018).

\section{Litter and forest floor sampling:}

To collect leaf litter, 38.1 x $53.34 \mathrm{~cm}\left(0.203 \mathrm{~m}^{2}\right)$ plastic litter traps were randomly placed and anchored at ground level within each plot. Litter was collected in the late fall of 2016, and again 
in early spring of 2017 to capture all potential leaf litter that fell throughout the winter of 20162017. Forest floor samples were collected by randomly placing a 31.75 x $22.86 \mathrm{~cm}\left(0.073 \mathrm{~m}^{2}\right)$ template upon the ground, and collecting the material within the template, replicated 3 times. Several plots were excluded from the forest floor analysis due to high tree mortality. Because these plots lacked a canopy, herbaceous species from the surrounding field encroached into the study area, and did not allow the development of a forest floor layer.

Sub-samples of both litter and forest floor material were oven dried at $65^{\circ} \mathrm{C}$ for 96 hours and weighed to determine gravimetric moisture content. A second set of sub-samples were then ground in a Wiley-Mill grinder. Bulk $\mathrm{C}$ and $\mathrm{N}$ of each sample were measured from 5-10 mg of air dried, ground litter or forest floor material in $12 \mathrm{~mm}$ tin capsules, and combusted within a NA 1500 Series 2 CNS element analyzer (Carlo Erba Instruments). Bulk C and N were then corrected for moisture and bulk density, and used to calculate $\mathrm{C}: \mathrm{N}$ ratios and scaled into standing pools of $\mathrm{kg} \mathrm{C}$ or $\mathrm{N} \mathrm{ha}^{-1}$.

\section{Biomass and $C$ content estimation}

Biomass for each plot was estimated by measuring the diameter at breast height (DBH) of each stem within a square subplot centered around a randomly selected tree. Subplot size was dependent upon tree density treatment. 1 x $1 \mathrm{~m}$ spacing plots had a subplot size of $1.5 \times 1.5 \mathrm{~m}$, while the $2 \times 2 \mathrm{~m}$ spacing treatment had subplots of $2.5 \times 2.5 \mathrm{~m}$. For individual trees that split into two stems below breast height, each stem was measured separately to more accurately account for biomass production. 
Individual stem biomass was calculated in the spring of 2017 using DBH measures and applying a species-specific allometric equation for similarly aged stands of oak, a family-specific equation for black cherry, and a general hardwood allometric equation for chestnut (Chojnakcy et al. 2013; Jenkins et al. 2003; Elliot et al. 2003) (Table 2.2). The mass of each tree within a plot was then summed, divided by the area of the subplot and converted into terms of $\mathrm{Mg} \mathrm{ha}^{-1}$. A previous study at this site had biomass estimations as well, but only had data for the first 4 years of growth (Gauthier et al. 2013). Carbon pools within AGB were then calculated using mean C concentration by weight for each species measured in previous studies (Lamlom \& Savidge 2003; Jacobs et al. 2009) (Table 2.2).

\section{Soil sampling:}

To examine the effect of tree species on mineral soil $\mathrm{C}$ and $\mathrm{N}$, soils were collected from each of the eight study plots for each block. Several plots at the study site had some tree mortality, but plots were included if enough trees were alive to allow soil samples to be collected from closedcanopy areas that would be influenced by litter and roots. Soil cores of the top $5 \mathrm{~cm}$ of the Ap horizon were collected from 3 random points within each plot, stored within plastic bags and transported back to the laboratory for further processing during the summer of 2016. Samples from 5-15 and 15-25 cm depth were collected as well, but not analyzed due to time constraints, and due to the young age of the stand, it was hypothesized that litter inputs to the top of the soil would have a larger impact than root inputs. A second set of cores were also collected within sleeves of a known volume for bulk density measurements. 
Bulk density sample cores were oven dried for 96 hours at $105^{\circ} \mathrm{C}$ and weighed to determine density. Soil samples were air-dried and sieved through a 2-mm sieve. Gravimetric moisture content was determined by oven drying $\sim 10 \mathrm{~g}$ sub samples at $105^{\circ} \mathrm{C}$ for $72 \mathrm{~h}$. Bulk $\mathrm{C}$ and $\mathrm{N}$ of each sample were measured by as CNS element analyzer as described above. Bulk C and N were then corrected for moisture and bulk density, and scaled into pools of $\mathrm{kg} \mathrm{C}$ or $\mathrm{N} \mathrm{ha}^{-1}$.

\section{Isotopic sampling and analyses:}

For the main isotopic study, soil was collected from the top three mineral horizons of each of the 18 study plots. Samples were composited from three cores collected from random points in each plot. Foliar samples were collected using a pole saw from three randomly selected trees per plot. Three leaves were collected from each tree, and were taken from the canopy exposed to full or partial sunlight. In addition, samples from each horizon and crop residues were collected from outside the study area from an adjacent field maintained in corn, to be used as the second input with the collected foliage. The collection of and analysis of roots was outside the scope of this study. As no $\mathrm{C}_{3}$ photosynthesis was present at this exterior site, it could be used to approximate the $\delta^{13} \mathrm{C}$ of corn inputs to the study area prior to the planting of the plantation.

The soil samples were sieved through a 2-mm sieve to remove coarse fragments and large pieces of organic matter. Approximately $150 \mathrm{mg}$ of sieved soil from each sample were weighed out into $2 \mathrm{~mL}$ centrifuge tubes. Each sample was then treated with $1 M \mathrm{HCl}$ to remove any carbonates present due to liming, as carbonate typically has a distinct $\delta^{13} \mathrm{C}$ signature that would bias the sample. Samples were vortexed for two minutes, and then allowed to sit overnight to allow any carbonate to react out with the $\mathrm{HCl}$. The $\mathrm{HCl}$ was decanted from the centrifuge tubes, 
and deionized (DI) water was added. Samples were spun in a centrifuge for 3 minutes at 3000 $\mathrm{rpm}$, and allowed to settle before decanting the DI water. This process was repeated until the $\mathrm{pH}$ of the DI water after centrifuging was the same as the $\mathrm{pH}$ of DI water before being added to the soil. Foliage and corn residue samples were processed through a Wiley-Mill grinder as described above. The treated soil and ground litter were weighed into sample tins, and analyzed for the ratio of ${ }^{12} \mathrm{C}$ and ${ }^{13} \mathrm{C}$ using a Thermo Finnigan Delta gas isotope ratio mass spectrometer connected to a High-Temperature Conversion Element Analyzer and GC IsoLink (Thermo Fisher Scientific). For each species, the litter and corn residue $\delta^{13} \mathrm{C}$ were used along with soil $\delta^{13} \mathrm{C}$ to evaluate the proportion of $\mathrm{C}_{3}$ - and $\mathrm{C}_{4}$-derived $\mathrm{C}$ within the soil. A sub-sample of the foliage was used to measure bulk $\mathrm{C}, \mathrm{N}$, and $\mathrm{C}: \mathrm{N}$ ratio as described above.

A preliminary analysis was done in the summer of 2017 as a proof of concept to investigate if an isotopic approach would be a viable method of evaluating $\mathrm{C}$ inputs to the soil derived from each species. A single $5 \mathrm{~cm}$ soil core was taken from each $2 \mathrm{~m}$ spacing plot for all three blocks, along with a core from outside of each block in the herbaceous field, to test if the field retained $\delta^{13} \mathrm{C}$ similar to what would be expected from a corn field. Soil samples were decarbonated and prepared for analysis as described above.

\section{Data Analysis:}

For each pool and flux of C and N (AGB C, soil C and N, leaf litter and forest floor C and N, $\delta^{13} \mathrm{C}$ ), the data were compiled and statistically analyzed using version 13.0 of SAS-JMP software. Model effects for the statistical analysis were spacing and species composition in a 
two-way ANOVA. Residuals were first checked for normality using the Shapiro-Wilke test. If the data for a pool deviated from normality, a transformation was applied to confirm to the assumptions required for ANOVA tests. For bulk $\mathrm{C}$ and $\mathrm{N}$ data in soils, 3 laboratory replicate cores were collected per plot, and the mean of the three values were analyzed using the two-way ANOVA model. C pools in AGB, litter, forest floor and soil were analyzed separately, and then combined and analyzed as total C stored in each plot. Tukey-Kramer HSD tests were performed post-hoc for comparisons between species if species was found to differentially effect the mean of a target pool or flux.

The $\delta^{13} \mathrm{C}$ input values for the litter and soil from each plot were used in a simple 2-point mixing equation to calculate the relative abundance of $\mathrm{C}_{3}$ and $\mathrm{C}_{4}$ derived $\mathrm{SOM}$ in each sample. Percent of total SOM derived from $\mathrm{C}_{4}$ was calculated first:

$$
\begin{aligned}
& \left.\% \mathrm{C}_{4}=\left[\left(\delta^{13} \text { Csample } \delta^{13} \mathrm{C}_{3}\right) / \delta^{13} \mathrm{C}_{4}-\delta^{13} \mathrm{C}_{3}\right)\right] * 100 \text { (Cerri et al. 1985) } \\
& \% \mathrm{C}_{3}=100-\% \mathrm{C}_{4}
\end{aligned}
$$

The values of $\% \mathrm{C}_{3}$-derived SOM where then used in the statistical model with spacing and species as effects.

\section{Results}

Foliage, Litter and Forest floor C and N:

Foliage $\% \mathrm{C}, \% \mathrm{~N}$ and $\mathrm{C}: \mathrm{N}$ ratio did not show any significant differences among Species or the Spacing treatment (Table 2.1). Leaf litter $\mathrm{C}$ concentration and $\mathrm{C}: \mathrm{N}$ ratio did not have any significant differences between species or the Spacing treatment as well. However, litter N concentration data required the removal of an outlier to conform to assumption of normality 
required to use ANOVA and was dependent upon species $(\mathrm{p}=0.0032)$, with chestnut and oak litter $\mathrm{N}$ concentration significantly higher than cherry (Table 2.1). Forest floor $\mathrm{C}$ concentration did not vary by species or spacing treatment. However, forest floor $\mathrm{N}$ concentration was dependent upon species $(\mathrm{p}=0.0178)$, with chestnut material $(0.98 \% \mathrm{~N})$ significantly lower than oak $(1.38 \% \mathrm{~N})$, with cherry material $(1.19 \% \mathrm{~N})$ not significantly different from either (Table 2.1). There was also a difference in forest floor $\mathrm{C}: \mathrm{N}$ ratio among species $(\mathrm{p}=0.0022)$, with chestnut material significantly higher $(\mathrm{C}: \mathrm{N}=43.59)$ than oak material $(\mathrm{C}: \mathrm{N}=32.29)$, but not cherry $(\mathrm{C}: \mathrm{N}=37.77)$ (Table 2.1).

Total forest floor mass was dependent upon species $(\mathrm{p}<0.05)$, with oak forest floor mass $(9262$ $\left.\mathrm{kg} \mathrm{ha}^{-1}\right)$ significantly greater than cherry $\left(3536 \mathrm{~kg} \mathrm{ha}^{-1}\right)$, while chestnut $\left(7679 \mathrm{~kg} \mathrm{ha}^{-1}\right)$ was not significantly different from either (Figure 2.1). Mean forest floor C content was dependent upon species $(\mathrm{p}=0.0421)$, with mean oak C $\left(4024 \mathrm{~kg} \mathrm{C} \mathrm{ha}^{-1}\right)$ significantly greater than cherry $(1574$ $\mathrm{kg} \mathrm{C} \mathrm{ha-1})$, and chestnut forest floor $\mathrm{C}\left(3195 \mathrm{~kg} \mathrm{C} \mathrm{ha}^{-1}\right)$ not significantly separated from either (Figure 2.1). For the parameters of total forest floor mass and forest floor $\mathrm{C}$ and $\mathrm{N}$ pools, no significant interaction effects (spacing * species) were noted. Forest floor $\mathrm{N}$ content was also dependent upon species $(\mathrm{p}=0.0023)$, with oak forest floor $\mathrm{N}$ pools $\left(123.3 \mathrm{~kg} \mathrm{~N} \mathrm{ha}^{-1}\right)$ significantly greater than chestnut $\left(72.84 \mathrm{~kg} \mathrm{~N} \mathrm{ha}^{-1}\right)$ and cherry (42.02 $\mathrm{kg} \mathrm{N} \mathrm{ha}^{-1}$ ) pools (Figure 2.1). Total leaf litter mass and litter $\mathrm{C}$ and $\mathrm{N}$ fluxes were all dependent upon species $(\mathrm{p}=$ 0.0017, $\mathrm{p}=0.0014, \mathrm{p}=0.0027$, respectively), and did not have any model interactions between species and spacing. For litter mass, $\mathrm{C}$, and N, each pool exhibited the same pattern, with oak and chestnut pools significantly larger than cherry pools (Figure 2.2). 


\section{$A G B$ and $C$ in Biomass:}

Mean AGB was dependent upon spacing treatment $(\mathrm{p}=0.0024)$ and species $(\mathrm{p}=0.0068)$.

Overall, chestnut plots had the greatest mean biomass $\left(86,695 \mathrm{~kg} \mathrm{ha}^{-1}\right)$, significantly greater than cherry biomass $\left(33,921 \mathrm{~kg} \mathrm{ha}^{-1}\right)$, but not statistically significantly greater than oak biomass $\left(58,346 \mathrm{~kg} \mathrm{ha}^{-1}\right)$ (Figure 2.3). This pattern was also documented for mean biomass C, which was dependent upon both spacing $(\mathrm{p}=0.0024)$ and species $(\mathrm{p}=0.0090)$, with chestnut plots $(40,349$ $\left.\mathrm{kg} \mathrm{C} \mathrm{ha}^{-1}\right)$ containing significantly greater amounts of $\mathrm{C}$ in biomass than cherry plots $(16,801 \mathrm{~kg}$ $\left.\mathrm{C} \mathrm{ha}^{-1}\right)$, though oak $\left(27,141 \mathrm{~kg} \mathrm{C} \mathrm{ha}^{-1}\right)$ was not significantly separate from either (Figure 2.4).

\section{Bulk Soil C and Isotopic Analysis:}

Soil C content was not differentially affected by species or spacing treatment, and did not have any significant model interactions (Figure 2.4). Total soil $\mathrm{N}$ content also was not differentially affected by species, but was dependent upon spacing $(\mathrm{p}=0.0169)$, with mean soil $\mathrm{N}$ in $2 \mathrm{~m}$ spacing treatments $\left(707.76 \mathrm{~kg} \mathrm{~N} \mathrm{ha}^{-1}\right)$ greater than that of the $1 \mathrm{~m}$ treatment $\left(614.65 \mathrm{~kg} \mathrm{~N} \mathrm{ha}^{-1}\right)$ (Figure 2.4).

The preliminary $\mathrm{C}$ isotope data did not have any statistical differences in mean $\delta^{13} \mathrm{C}$ between species or the herbaceous field outside the study site $(\mathrm{p}=0.1635)$ (Figure 2.6). Final results of the full isotope analysis are forthcoming.

Total ecosystem $\mathrm{C}$ measured within each plot was dependent upon both spacing $(\mathrm{p}=0.0156)$ and species $(\mathrm{p}=0.0390)$. Total ecosystem $\mathrm{C}$ within chestnut plots $\left(55,261 \mathrm{~kg} \mathrm{C}^{-1}\right)$ was $93 \%$ 
greater and significantly greater than total C within cherry plots $\left(28,526 \mathrm{~kg} \mathrm{C} \mathrm{ha}^{-1}\right)$, and $40 \%$ greater, but not significantly different, than oak plots $\left(39,488 \mathrm{~kg} \mathrm{C} \mathrm{ha}^{-1}\right)$ (Figure 2.5).

\section{Discussion:}

There did appear to be a species-driven trend in total pools of ecosystem C, indicating that chestnut plots contained $93 \%$ more C than cherry plots, and $40 \%$ more than oak plots (Figure 2.5). However, while total $\mathrm{C}$ in chestnut plots was significantly greater than cherry plots, mean total C present in chestnut plots was not statistically separate from oak plots, and therefore only partially supports hypothesis 1 that chestnut would result in greater ecosystem C storage than oak or cherry. The lack of statistically significant differences between chestnut and oak ecosystem C, despite chestnut having $40 \%$ greater $\mathrm{C}$ than oak may be due to limitations of the statistical design of the field site, which has limited replication, or could be attributed to the young age of the stand. In addition, there is a trend in chestnut having greater $\mathrm{C}$ storage in biomass relative to oak or cherry, which comprised $73 \%$ of total $\mathrm{C}$ in chestnut plots, $59 \%$ of total C in cherry plots and $69 \%$ of total $\mathrm{C}$ in oak plots.

The data from this study indicate that mean forest floor $\mathrm{C}$ beneath chestnut was not significantly different from mean forest floor $\mathrm{C}$ of oak or cherry. In addition, while mean $\mathrm{C}$ in chestnut litter was significantly higher than cherry litter, it was not different from oak, and appears to be driven by total amount of litter mass, as there were no differences in litter $\mathrm{C}$ concentration between species. This does not support the hypothesis that chestnut would have greater $\mathrm{C}$ in fluxes of leaf 
litter and pools of forest floor material compared to oak and cherry. While not statistically significant, mean chestnut forest floor $\mathrm{C}$ was $107 \%$ greater than forest floor $\mathrm{C}$ in cherry plots, but again appears to be driven by total forest floor mass. As the stand ages, the difference in forest floor $\mathrm{C}$ between species may become more apparent.

Pool size of $\mathrm{N}$ in chestnut forest floor material was significantly smaller than that of oak, but not different from cherry, while the flux of $\mathrm{N}$ in chestnut litter were significantly greater than cherry, but not oak. These results partially support the hypothesis that pools and fluxes of $\mathrm{N}$ would be smaller in chestnut litter and forest floor material than in oak and cherry. While the pattern in total $\mathrm{N}$ in leaf litter appears to be mostly total mass driven, the $\mathrm{N}$ concentration of leaf litter and forest floor material indicates that cherry has lower $\% \mathrm{~N}$ in leaf litter than oak or chestnut. This indicates that if the total mass of cherry leaf litter were similar to chestnut or oak, it would still contain less $\mathrm{N}$. However, cherry litter has a much larger variation of $\mathrm{N}$ concentration values among samples, and has fewer replicates than oak or chestnut due to mortality in cherry plots, and required the removal of an outlier to achieve normality of residuals. These factors may help explain why total $\mathrm{N}$ pool size in cherry was lower than oak or chestnut plots.

Chestnut forest floor $\mathrm{N}$ concentration was significantly lower than oak, and lower, though not significantly different than cherry, indicating that chestnut forest floor material of the same mass of oak or cherry contains less total N. This can be seen in Figure 2.1, where there is no significant difference in mass between oak and chestnut forest floor material, but chestnut material contains significantly less total $\mathrm{N}$. This is fitting with the proposed differences in strategies of litter chemistry and N cycling and acquisition between ECM and AM fungi and 
hosts plants, where ECM fungi can more readily access organic forms of $\mathrm{N}$ and requires less excess N mineralization than AM fungi (Phillips et al. 2013; Lin et al. 2017). This aligns with the study by Finzi et al. 1998 at Canaan Plateau in Connecticut, who found the C:N ratio and $\mathrm{N}$ in the forest floor of were greater beneath the AM species sugar maple than the ECM species red oak. Although red oak in this study does not follow this trend, the $\mathrm{C}$ and $\mathrm{N}$ data from cherry and chestnut plots fits within this framework.

Mean AGB and C in biomass were significantly greater for chestnut than in cherry, and greater, though not significantly so, than oak. This partially supports the hypothesis that chestnut would grow faster and contain more $\mathrm{C}$ in biomass than the other species present at the site, but does not align with previous studies that have found chestnut to specifically outcompete oak (Jacobs \& Severeid 2004; Jacobs et al. 2009). However, the mean total AGB for chestnut plots was $49 \%$ larger than oak plots, while a previous study, also at the Martell Forest site from 2007-2011, reported that chestnut had the poorest early growth performance and shortest mean height of the three species present (Gauthier et al. 2013). This may suggest that the chestnut at this site are beginning to grow at a faster rate relative to oak, and in the future, the trend in greater chestnut biomass may become significant over time. As reported in Jacobs et al. 2009, chestnut and oak have similar C content in woody biomass (Table 2.1), and so differences in AGB C are determined by the amount of biomass of each species. Previous studies have shown that cherry has a higher $\mathrm{C}$ content in woody biomass than chestnut or oak, but had much less biomass at the study site, and $\mathrm{C}$ in biomass was still significantly lower than in chestnut. 
Species did not differentially affect total pools of $\mathrm{C}$ or $\mathrm{N}$ in the top $5 \mathrm{~cm}$ of mineral soil, contrary to the hypothesis that soils beneath chestnut would have greater $\mathrm{C}$ accumulation than oak due to poorer-quality litter, and greater $\mathrm{C}$ accumulation compared to cherry due to the differential AMECM fungal influences on C and N dynamics (Finzi et al. 1998; Philips et al 2013; Taylor et al. 2016). Unlike the above-ground $\mathrm{C}$ pools that exhibited up to $93 \%$ difference in pool size among species, though statistically non-significant, the difference in total soil $\mathrm{C}$ and $\mathrm{N}$ among species was minimal. Possible explanations of this could be that these species do not have differential rates of $\mathrm{C}$ storage below-ground, or that because the plantation was only 9 years old at the time of soil sampling during the summer of 2016 and there was not sufficient time for the trees to alter the very large pool of total soil $\mathrm{C}$ in a meaningful way from its history as a monoculture field (Lal 2005).

The preliminary isotopic analysis did not show statistically significant differences between species, and the herbaceous field core values were similar to the tree species. While $\delta^{13} \mathrm{C}$ values of a typical corn field can vary from $-16 \%$ to $-24 \%$, past studies directly comparing $\delta^{13} \mathrm{C}$ values of forest and corn field SOM differed by up to $5 \%$ in upper soil horizons (Gregorich et al. 1995; Wilts et al. 2004). This did not support the hypothesis that SOM in chestnut plots would be isotopically more depleted than the other species due to recalcitrant litter material causing an accumulation of $\mathrm{C} 3$ derived SOM. However, as the field itself was not separate from the plots, this could be due to the herbaceous field possibly having a significant $\mathrm{C}_{3}$ photosynthesis component, or that there has not been sufficient time for $\mathrm{C}_{3}$-derived SOM to change the $\delta^{13} \mathrm{C}$ values of the soil inside the plantation. The main isotopic study, which is still in the process of 
being analyzed, included more replication, soils down to $30 \mathrm{~cm}$, and soil and crop residue from an adjacent corn field can perhaps explain this.

\section{Conclusions}

In conclusion, this study has found several differences in $\mathrm{C}$ and $\mathrm{N}$ dynamics between chestnut and the other species present at the study site. Chestnut had significantly greater above-ground biomass and $\mathrm{C}$ in biomass than cherry, and a non-significant trend in greater biomass and biomass $\mathrm{C}$ than oak. Lastly, while there was no difference in bulk $\mathrm{C}$ or $\mathrm{N}$ in soil, there were differences in the preliminary $\mathrm{C}$ isotope analysis, indicating a potential differential rate of $\mathrm{C}$ inputs below ground among species, which could be detected by the full repetition analysis still in progress. Overall, these results indicate that chestnut could be a useful species upon its reintroduction for increasing $\mathrm{C}$ sequestration in Appalachian hardwood forests as indicated by the greater total ecosystem $\mathrm{C}$ present in the chestnut plots relative to either cherry or oak. 


\section{Literature Cited}

Abrams, M. D., Schultz, J. C., \& Kleiner, K. W. (1990). Ecophysiological responses in mesic versus xeric hardwood species to an early-season drought in central Pennsylvania. Forest Science, 36(4), 970-981.

Averill C, Turner BL, Finzi AC. 2014. Mycorrhiza-mediated competition between plants and decomposers drives soil carbon storage. Nature 505: 543-545.

Bellassen, V., \& Luyssaert, S. (2014). Carbon sequestration: Managing forests in uncertain times. Nature, 506(7487), 153-155.

Bender, M. M. (1971). Variations in the $13 \mathrm{C} / 12 \mathrm{C}$ ratios of plants in relation to the pathway of photosynthetic carbon dioxide fixation. Phytochemistry, 10(6), 1239-1244.

Budget, G. C. (2016). Corinne Le Quéré et al. Earth Syst. Sci. Data, 8, 605-649.

Canadell, J. G., \& Raupach, M. R. (2008). Managing forests for climate change mitigation. science, 320(5882), 1456-1457.

Cerri, C., Feller, C., Balesdent, J., Victoria, R., \& Plenecassagne, A. (1985). Application du traçage isotopique naturel en $13 \mathrm{C}$, à l'étude de la dynamique de la matière organique dans les sols. Comptes-rendus des séances de l'Académie des sciences. Série 2, Mécanique-physique, chimie, sciences de l'univers, sciences de la terre, 300(9), 423-428.

Chojnacky, D. C., Heath, L. S., \& Jenkins, J. C. (2013). Updated generalized biomass equations for North American tree species. Forestry, 87(1), 129-151.

Elliott, K. J., Boring, L. R., \& Swank, W. T. (2002). Aboveground biomass and nutrient accumulation 20 years after clear-cutting a southern Appalachian watershed. Canadian Journal of Forest Research, 32(4), 667-683.

Ellison, A. M., Bank, M. S., Clinton, B. D., Colburn, E. A., Elliott, K., Ford, C. R., ... \& Mohan, J. (2005). Loss of foundation species: consequences for the structure and dynamics of forested ecosystems. Frontiers in Ecology and the Environment, 3(9), 479-486. 
Finzi, A. C., Van Breemen, N., \& Canham, C. D. (1998). Canopy tree-soil interactions within temperate forests: species effects on soil carbon and nitrogen. Ecological applications, 8(2), 440446.

Gauthier, M., Zellers,K., E, Löf, M, Jacobs, D., F. (2013). Inter- and intra-specific competitiveness of plantation-grown American chestnut (Castanea dentata). Forest Ecology and Management, 291, 289-299

Gregorich, E. G., Monreal, C. M., \& Ellert, B. H. (1995). Turnover of soil organic matter and storage of corn residue carbon estimated from natural 13C abundance. Canadian Journal of Soil Science, 75(2), 161-167.

Jacobs, D. F., Dalgleish, H. J., \& Nelson, C. D. (2013). A conceptual framework for restoration of threatened plants: the effective model of American chestnut (Castanea dentata) reintroduction. New Phytologist, 197(2), 378-393.

Jacobs, D. F., Selig, M. F., \& Severeid, L. R. (2009). Aboveground carbon biomass of plantation-grown American chestnut (Castanea dentata) in absence of blight. Forest Ecology and Management, 258(3), 288-294.

Jandl, R., Lindner, M., Vesterdal, L., Bauwens, B., Baritz, R., Hagedorn, F., ... \& Byrne, K. A. (2007). How strongly can forest management influence soil carbon sequestration? Geoderma, 137(3), 253-268.

Jenkins, J. C., Chojnacky, D. C., Heath, L. S., \& Birdsey, R. A. (2003). National-scale biomass estimators for United States tree species. Forest Science, 49(1), 12-35.

Lal, R. (2005). Forest soils and carbon sequestration. Forest ecology and management, 220(1-3), 242-258.

Lamlom, S. H., \& Savidge, R. A. (2003). A reassessment of carbon content in wood: variation within and between 41 North American species. Biomass and Bioenergy, 25(4), 381-388.

Li, A., \& Fahey, T. J. (2013). Nitrogen translocation to fresh litter in northern hardwood forest. Ecosystems, 16(3), 521-528.

Lin, G., McCormack, M. L., Ma, C. and Guo, D. (2017), Similar below-ground carbon cycling dynamics but contrasting modes of nitrogen cycling between arbuscular mycorrhizal and ectomycorrhizal forests. New Phytol, 213: 1440-1451.

Lovett, G. M., Weathers, K. C., \& Arthur, M. A. (2002). Control of Nitrogen Loss from Forested Watersheds by Soil Carbon: Nitrogen Ratio and Tree Species Composition. Ecosystems, 5(7), 0712-0718. 
Magill, A. H., Aber, J. D., Berntson, G. M., McDowell, W. H., Nadelhoffer, K. J., Melillo, J. M., \& Steudler, P. (2000). Long-term nitrogen additions and nitrogen saturation in two temperate forests. Ecosystems, 3(3), 238-253.

Marshall, J. D., Brooks, J. R., \& Lajtha, K. (2007). Sources of variation in the stable isotopic composition of plants. Stable isotopes in ecology and environmental science, 2, 22-60.

National Climatic Data Center, 2012. United States Climate Normals 1981-2010. West Lafayette 6NW Station, Indiana. http://gis.ncdc.noaa.gov/map/cdo/ (accessed 19.01.18).

O'Leary, M. H. (1988). Carbon isotopes in photosynthesis. Bioscience, 38(5), 328-336.

Peichl, M., \& Arain, M. A. (2006). Above-and belowground ecosystem biomass and carbon pools in an age-sequence of temperate pine plantation forests. Agricultural and Forest Meteorology, 140(1-4), 51-63.

Peterjohn, W. T., Foster, C. J., Christ, M. J., \& Adams, M. B. (1999). Patterns of nitrogen availability within a forested watershed exhibiting symptoms of nitrogen saturation. Forest Ecology and Management, 119(1), 247-257.

Phillips, R. P., Brzostek, E., \& Midgley, M. G. (2013). The mycorrhizal-associated nutrient economy: a new framework for predicting carbon-nutrient couplings in temperate forests. New Phytologist, 199(1), 41-51.

Pinchot, C. C., Schlarbaum, S. E., Clark, S. L., Saxton, A. M., Sharp, A. M., Schweitzer, C. J., \& Hebard, F. V. (2017). Growth, survival, and competitive ability of chestnut (Castanea Mill.) seedlings planted across a gradient of light levels. New Forests, 1-22.

Resh, S. C., Binkley, D., \& Parrotta, J. A. (2002). Greater soil carbon sequestration under nitrogen-fixing trees compared with Eucalyptus species. Ecosystems, 5(3), 217-231.

ROCKFIELD SERIES. (2007, May). National Cooperative Soil Survey. Retrieved April 11, 2017, from https://soilseries.sc.egov.usda.gov/OSD_Docs/R/ROCKFIELD.html

Schulp, C. J., Nabuurs, G. J., Verburg, P. H., \& de Waal, R. W. (2008). Effect of tree species on carbon stocks in forest floor and mineral soil and implications for soil carbon inventories. Forest ecology and management, 256(3), 482-490.

Ter-Mikaelian, M. T., \& Korzukhin, M. D. (1997). Biomass equations for sixty-five North American tree species. Forest Ecology and Management, 97(1), 1-24.

Van Cleve, K., \& Powers, R. F. (1995). Soil carbon, soil formation, and ecosystem development. Carbon forms and functions in forest soils, (carbonformsandf), 155-200.

Vesterdal L, Clarke N, Sigurdsson BD, Gundersen P. 2013. Do tree species influence soil carbon stocks in temperate and boreal forests? Forest Ecology and Management 309: 4-18. 
Wang, G. G., Knapp, B. O., Clark, S. L., \& Mudder, B. T. (2013). The Silvics of Castanea dentata (Marsh.) Borkh. American Chestnut, Fagaceae (Beech Family). US Forest Service, Southern Research Station. General Technical Report SRS-173.

Wilts, A. R., Reicosky, D. C., Allmaras, R. R., \& Clapp, C. E. (2004). Long-term corn residue effects. Soil Science Society of America Journal, 68(4), 1342-1351.

Yin, H., Wheeler, E., Phillips, R. P. (2014). Root-induced changes in nutrient cycling in forests depend on exudation rates. Soil Biology \& Biochemistry, 78, 213-221.

Youngs, R. L. (2000). "A Right Smart Little Jolt": Loss of the Chestnut and a Way of Life. Journal of Forestry, 98(2), 17-21.

Table 2.1: \% C, \% $\mathrm{N}$ and $\mathrm{C}: \mathrm{N}$ ratio of chestnut, cherry and oak foliage, leaf litter, and forest floor material. Values in parentheses are +/-1 SE of the mean. Values within a category that have different letters in parenthesis are significantly separate from one another by Tukey's HSD test.

\begin{tabular}{clllllll} 
& Species & \% C & & \% N & & C:N & \\
\hline & Chestnut & 44.9 & $(0.16)$ & 1.78 & $(0.09)$ & 25.41 & $(0.85)$ \\
& Cherry & 45.32 & $(0.67)$ & 1.94 & $(0.11)$ & 23.54 & $(1.24)$ \\
Foliage & Oak & 45.67 & $(0.35)$ & 1.97 & $(0.41)$ & 23.62 & $(1.41)$ \\
& & & & & & & \\
& Chestnut & 41.26 & $(1.88)$ & 1.87 & $(0.05)(\mathrm{A})$ & 22.09 & $(0.93)$ \\
$\begin{array}{c}\text { Leaf } \\
\text { Litter }\end{array}$ & Cherry & 45.75 & $(1.27)$ & 1.38 & $(0.02)(\mathrm{B})$ & 29.33 & $(4.77)$ \\
& Oak & 43.84 & $(1.67)$ & 1.81 & $(0.08)(\mathrm{A})$ & 24.64 & $(1.86)$ \\
& & & & & & & \\
Forest & Chestnut & 41.05 & $(1.93)$ & 0.94 & $(0.04)(\mathrm{A})$ & 43.59 & $(1.05)(\mathrm{A})$ \\
Floor & Oak & 44.05 & $(2.01)$ & 1.17 & $(0.04)(\mathrm{AB})$ & 37.77 & $(1.24)(\mathrm{AB})$ \\
\hline
\end{tabular}


Table 2.2: Allometric equations for calculating biomass from $\mathrm{DBH}, \mathrm{R}^{2}$ of allometric equations, and $\% \mathrm{C}$ of bole for American chestnut, black cherry and northern red oak.

\begin{tabular}{|c|c|c|c|c|}
\hline Species & $\begin{array}{l}\text { Biomass allometric } \\
\text { equation }\end{array}$ & $\mathbf{R}^{2}$ & $\% \mathrm{C}$ & Source \\
\hline $\begin{array}{l}\text { American } \\
\text { chestnut }\end{array}$ & $\begin{array}{l}\ln (\text { biomass })=-2.0127+ \\
2.4342 * \ln (\mathrm{DBH})\end{array}$ & 0.988 & 46.37 & $\begin{array}{l}\text { Jenkins et al. } 2003 \text { (Biomass) } \\
\text { Jacobs et al. } 2009 \text { (\% C) }\end{array}$ \\
\hline Black cherry & $\begin{array}{l}\ln (\text { biomass })=22.9255+ \\
2.4109 * \ln (\mathrm{DBH})\end{array}$ & 0.89 & 49.53 & $\begin{array}{l}\text { Chojnakcy et al. } 2013 \text { (Biomass) } \\
\text { Lamlon \& Savage } 2003 \text { (\% C) }\end{array}$ \\
\hline Northern red oak & $\begin{array}{l}\log _{10}(\text { biomass })=2.007+ \\
2.3505 * \log _{10}(\mathrm{DBH})\end{array}$ & 0.94 & 46.52 & $\begin{array}{l}\text { Elliot et al. } 2002 \text { (Biomass) } \\
\text { Jacobs et al. } 2009 \text { (\% C) }\end{array}$ \\
\hline
\end{tabular}




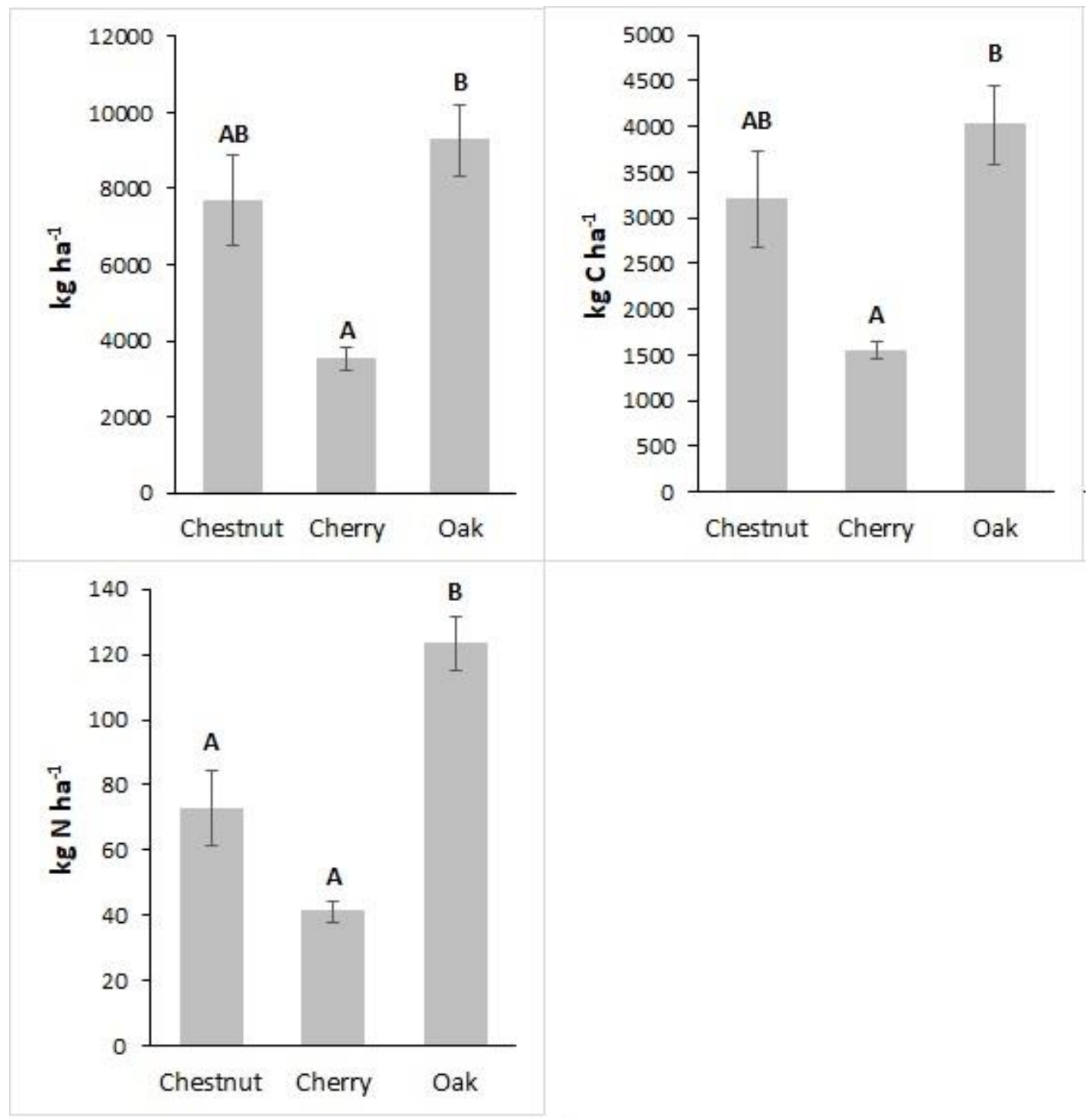

Figure 2.1: Mean forest floor total mass (top left), $\mathrm{C}$ (top right) and $\mathrm{N}$ (bottom left) pools (kg ha ${ }^{1}$ ) of chestnut, cherry and red oak plots. Bars with different letters are significantly different by Tukey's HSD test. Error bars represent $+/-1 \mathrm{SE}$ from the mean. 


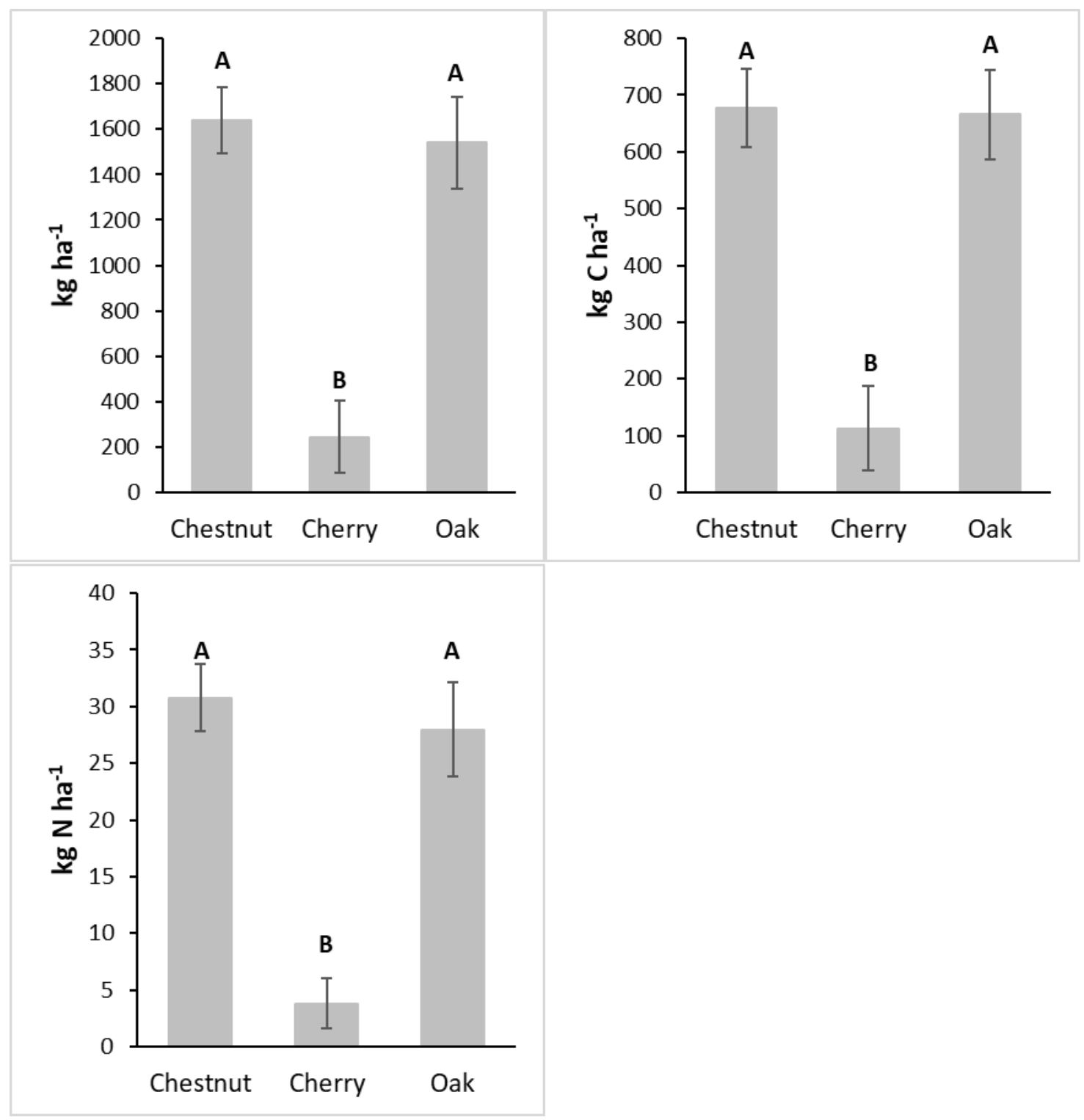

Figure 2.2: Mean total litter mass, (top left) $\mathrm{C}$ (top right) and $\mathrm{N}$ (bottom left) pools (kg/ha) of chestnut, cherry and red oak collected from 8/2016 - 6/2017. Bars with different letters are significantly different by Tukey's HSD test. Error bars represent +/- 1 SE from the mean. 


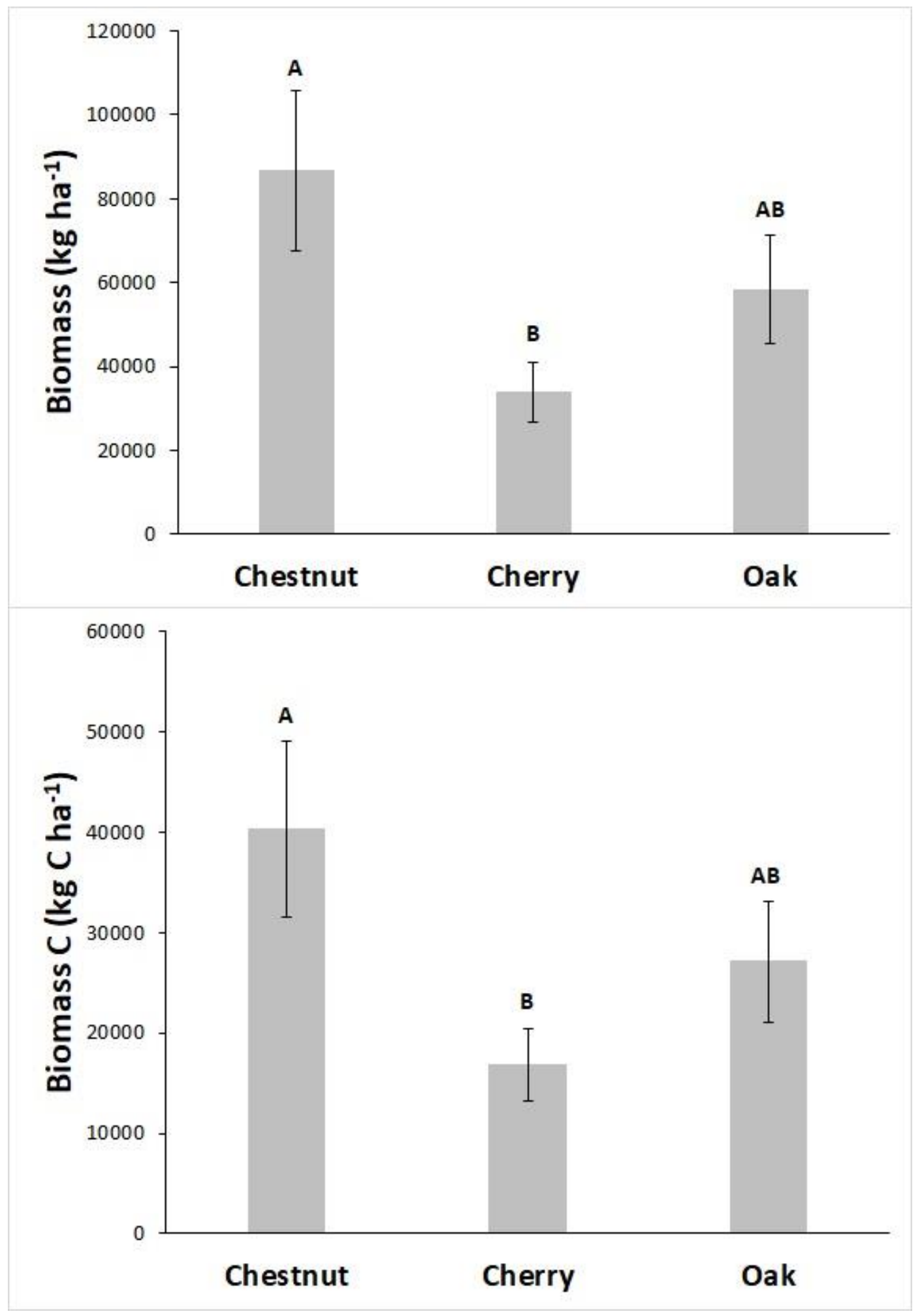

Figure 2.3: Mean above-ground biomass (top), and biomass $C$ (bottom) of chestnut, cherry and red oak plots. Bars with different letters are significantly different by Tukey's HSD test. Error bars represent +/- $1 \mathrm{SE}$ from the mean. 


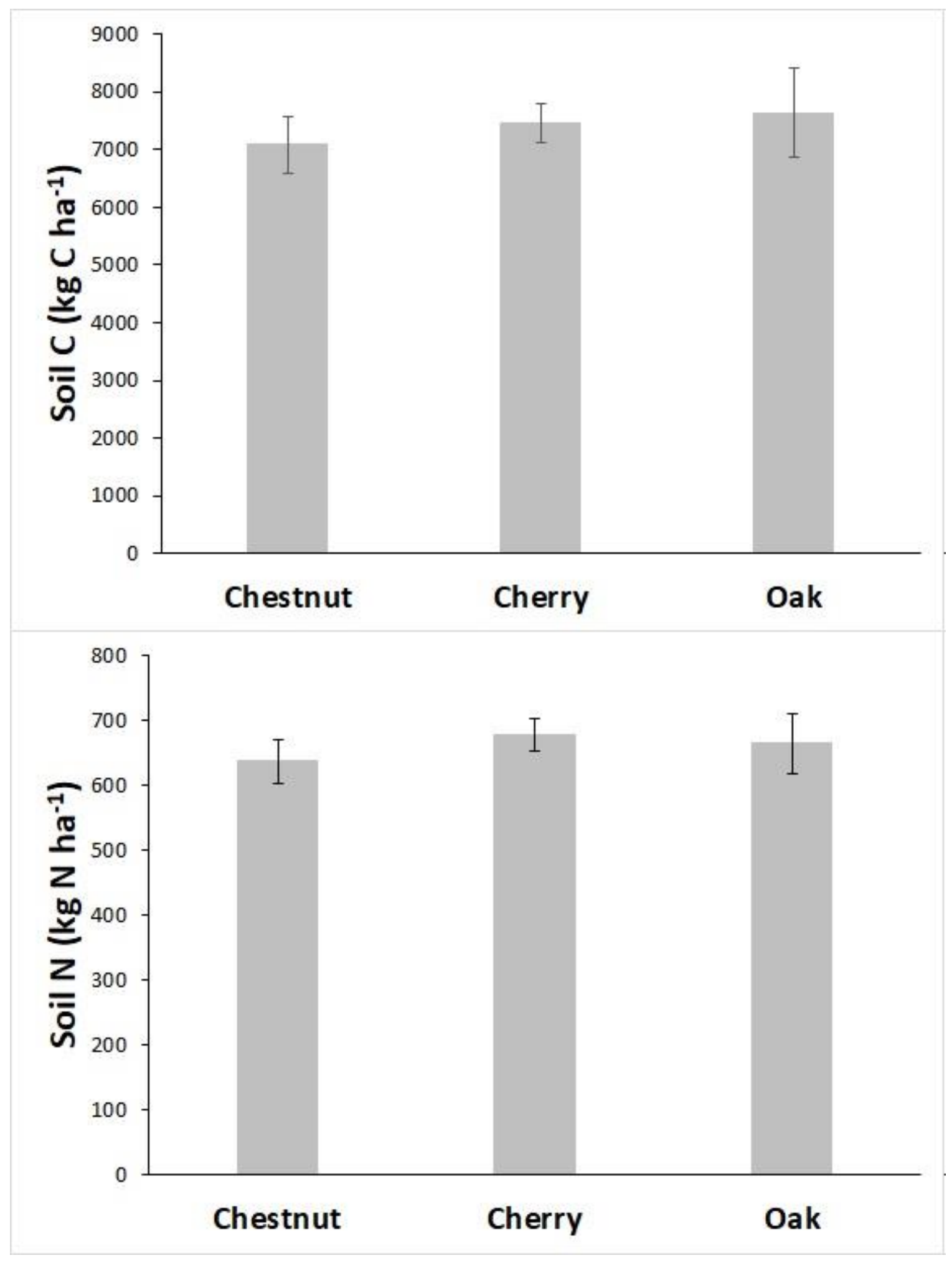

Figure 2.4: Mean back-transformed mineral soil C (top), and mean mineral soil N (bottom) of chestnut, cherry and red oak plots. Error bars represent $+/-1 \mathrm{SE}$ from the mean. 


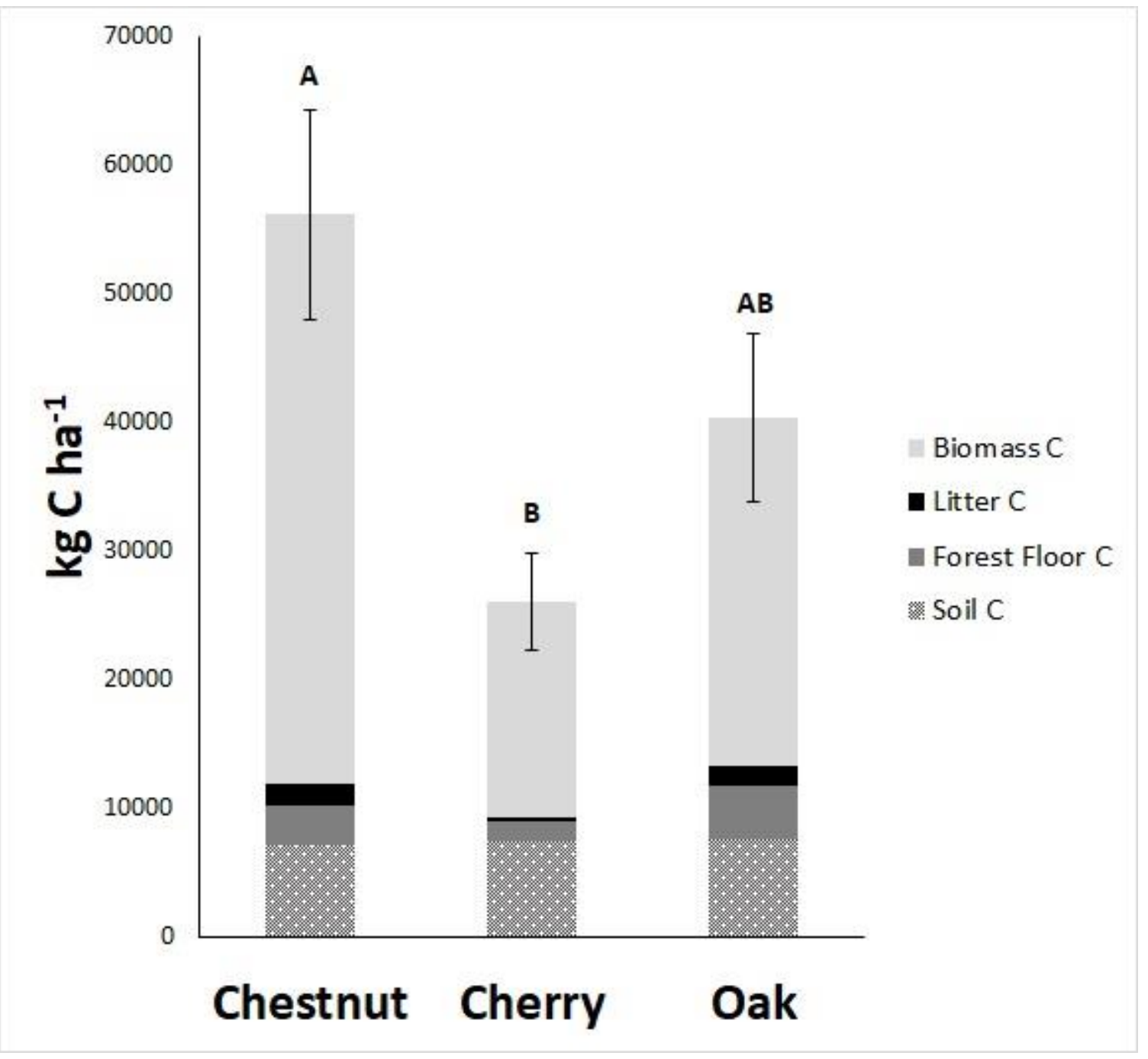

Figure 2.5: Mean total $\mathrm{C}$ present in plots of chestnut, cherry and oak, comprised of biomass, litter, forest floor and the top $5 \mathrm{~cm}$ of mineral soil. Bars with different letters are significantly different by Tukey's HSD test. Error bars represent +/- $1 \mathrm{SE}$ from the mean. 


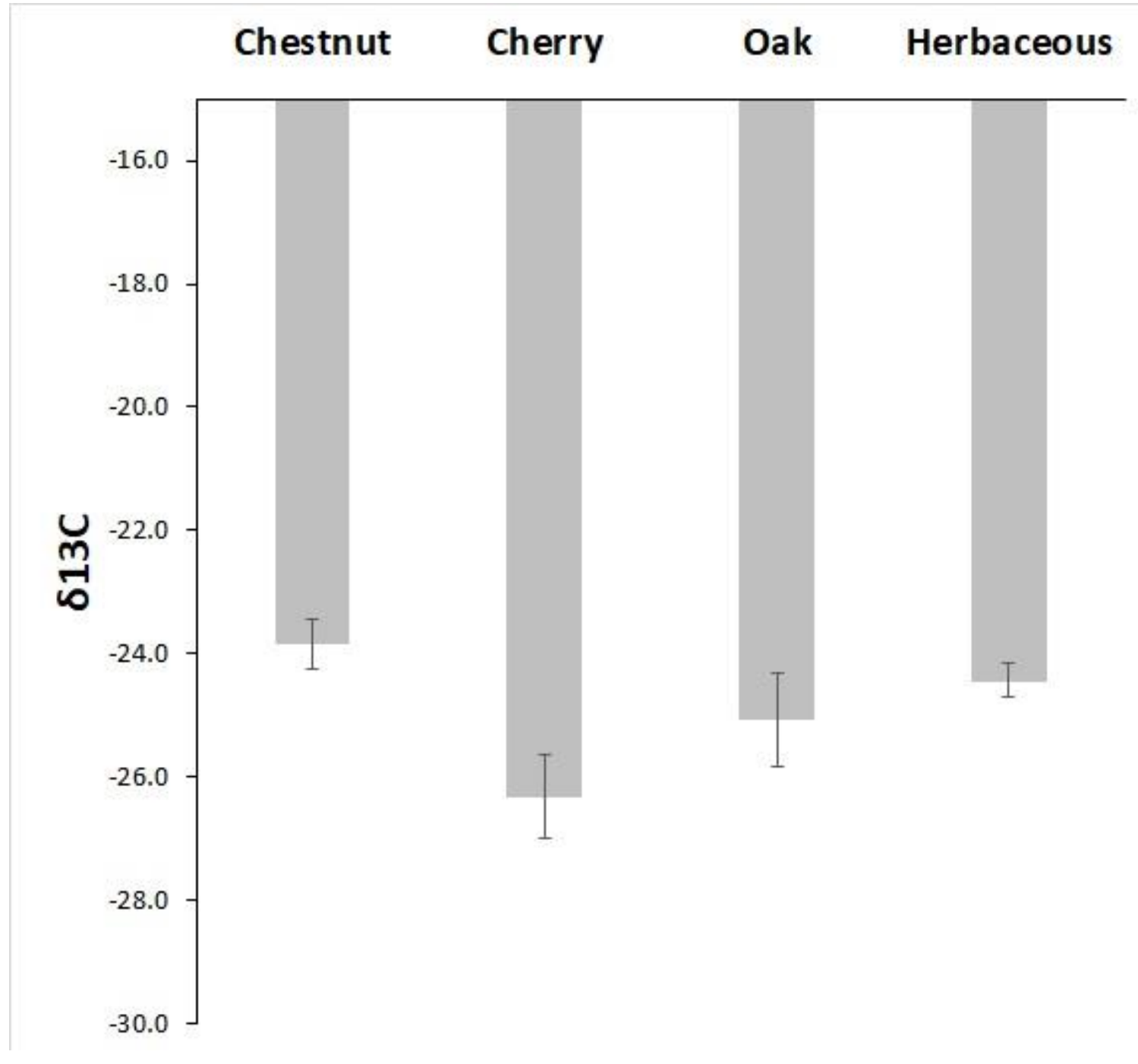

Figure 2.6: Mean $\delta^{13} \mathrm{C}$ values of soil cores from $2 \mathrm{~m}$ chestnut, cherry and oak plots, along with cores collected from outside each plot in the field. Error bars represent +/- 1 SE from the mean. 


\title{
Chapter 3:
}

\section{American chestnut reduces nitrogen mineralization in soil despite increased litter decomposition rates relative to black cherry and red oak in soil incubation experiment}

\begin{abstract}
Trees are capable of influencing soil $\mathrm{C}$ and $\mathrm{N}$ cycling through the chemical composition of their leaf and root litter, and mycorrhizal associations. At the turn of the $20^{\text {th }}$ century, American chestnut (Castenea dentata), a previously dominant and widespread canopy species throughout the eastern deciduous forest, was extirpated from its native range by chestnut blight fungus, an introduced species from Asia. Through development of blight-resistant trees, the reintroduction of American chestnut to its native range is considered imminent. However, relatively little is known about the biogeochemistry of forests influenced by chestnut, and how chestnut litter chemistry and fungal associations may have influenced below-ground dynamics of $\mathrm{C}$ and N. In this study, a one-year laboratory incubation of soil and litter collected beneath 10 year-old stands of American chestnut and two historically commonly co-occurring species, northern red oak (Quercus rubra) and black cherry (Prunus serotina) was conducted to measure important ecosystem fluxes and transformations of $\mathrm{C}$ and $\mathrm{N}$. Parameters included litter decomposition, $\mathrm{C}$ respiration, $\mathrm{N}$ mineralization, as well as explanatory variables of extracellular enzyme activity related to nutrient acquisition, litter chemistry (lignin and tannin content), and oxidizable C. Key findings from this study indicate that chestnut litter decayed more rapidly than that of oak or cherry (18.97\% mass lost in chestnut litter, 10.83\% mass loss in oak litter, $14.13 \%$ mass lost in cherry litter), and soil influenced by chestnut had lower $\mathrm{N}$ mineralization rates than soils influenced by oak or cherry $\left(7.84 \mathrm{mg} \mathrm{N} \mathrm{kg}^{-1}\right.$ in chestnut soils, $11.51 \mathrm{mg} \mathrm{N} / \mathrm{kg}^{-1}$ in cherry soils, $12.00 \mathrm{mg} \mathrm{N} \mathrm{kg}^{-1}$ in oak soils) and greater dissolved organic $\mathrm{C}$ (DOC) in leachate than soils influenced by oak (31.38 mg DOC kg-1 in chestnut soil, $26.39 \mathrm{mg} \mathrm{DOC} \mathrm{kg}^{-1}$ in oak soil), but no difference in $\mathrm{C}$ loss through soil respiration. Soil influenced by chestnut also had greater oxidizable $\mathrm{C}$, indicating a larger microbial biomass and pool size of processed $\mathrm{C}$, important for soil $\mathrm{C}$ storage. These results indicate that soils influenced by chestnut will have more rapid inputs of $\mathrm{C}$ and $\mathrm{N}$ through litter decomposition, will have lower inorganic $\mathrm{N}$ availability, and due to relatively low $\mathrm{C}$ respiration rates and high oxidizable $\mathrm{C}$, likely will result in an accumulation of soil C.
\end{abstract}




\section{Introduction}

Important forest biogeochemical shifts have likely occurred throughout the historic range of American chestnut (Castenea dentata) following its decline in the early 1900's (Ellison et al. 2005). As chestnut trees were lost from the forest canopy, co-occurring species such as oaks (Quercus spp.) and hickories (Carya spp.) replaced them (Vandermast et al. 2002; Ellison et al. 2005). However, chestnut was lost from Appalachian hardwood forests before the advent of modern ecology, and it is therefore unknown what ecosystem and biogeochemical changes resulted from the loss of this keystone species, and how these forested ecosystems may again change as chestnut is reintroduced.

Soil nutrient storage and cycling are influenced by numerous factors, such as soil texture, and vegetation type (Kogel-Knabner et al. 2008; Phillips et al. 2013; Cotrufo 2013). Tree species influence below-ground biogeochemical dynamics, such as decomposition and mineralization rates, through differences in allocation of $\mathrm{C}$ and $\mathrm{N}$ belowground, chemical composition of leaf and root litter, and associated microbial communities (Phillips et al. 2013). Importantly, the type of mycorrhizal fungi associated with tree species plays a role in $\mathrm{C}$ and $\mathrm{N}$ dynamics, although there are competing hypothesis as to how different types of mycorrhizae influence these dynamics. One model hypothesizes that relatively rapid decomposition of litter from arbuscular mycorrhizal (AM)-associated trees (e.g., cherry, maple, poplar) leads to greater inorganic nutrient availability microbial biomass and extracellular enzyme activity, and therefore greater $\mathrm{C}$ demand compared to ectomycorrhizal (ECM) associated tree species (e.g. chestnut, oak, hickory) (Averill et al. 2014; Taylor et al. 2016; Knelman et al. 2017). For example, Finzi et al. (1998) 
showed that $\mathrm{N}$ mineralization rates in soil beneath the AM-associated species red maple (Acer rubrum) were more than double that of soils beneath American beech (Fagus grandifolia), an ECM-associated species. The competing hypothesis is that the rapid decomposition and microbial processing of $\mathrm{N}$-rich $\mathrm{AM}$ litter results in highly processed and stable $\mathrm{C}$ compounds, resulting in greater long-term C storage belowground (Craig et al. 2018).

Because chestnut is associated with ECM fungi, it is thought that chestnut has relatively poor quality litter, with higher $\mathrm{C}: \mathrm{N}$ ratios and recalcitrant compound content, and slower belowground nutrient cycling when compared to trees with AM associations. This may have resulted in greater below ground C storage when compared to AM-associated species (Finzi et al. 1998; Schulp et al. 2008; Yin et al. 2014). However, previous studies have shown mixed evidence of chestnut litter quality; some studies have shown chestnut litter may have lower $\mathrm{C}: \mathrm{N}$ ratios than other ECM species, such as the oaks and hickories that have replaced them (Ellison et al. 2005). In addition, it has been shown that chestnut litter also contains greater concentrations of other nutrients, such as phosphorus and calcium compared to mixed hardwood litter (Rhodes, 2006). Conversely, other studies have reported no differences in $\mathrm{C}: \mathrm{N}$ ratio between chestnut and other ECM tree litter (Rosenberg 2010). Given that wood produced by chestnut is also relatively high in tannin content, backed by the historical use of chestnut wood in the leather tanning industry (Wang et al. 2013), it is possible that chestnut leaf litter may contain high concentrations of tannins as well. Higher concentrations of tannins from leaf litter may impact soil nutrient cycling, as tannins are known to inhibit digestive enzymes and precipitate proteins, which may slow N mineralization (Hagerman \& Butler, 1981; Lovett et al. 2004) and influence soil C dynamics. It is therefore important to more accurately understand the quality of chestnut litter 
relative to contemporary dominant tree species. In addition, previous studies have not combined chestnut litter quality analysis with a direct investigation of how the litter mediates soil nutrient cycling and C dynamics.

Soil represents the largest stable terrestrial C pool (Batjes 2014); however, soil C storage is susceptible to vegetative changes. To create stable soil C, inputs from tree litter, root turnover, and microbial biomass undergo extensive processing by soil microbes to be sequestered as soil organic matter (SOM). Key fractions of total soil $\mathrm{C}$ useful for determining potential $\mathrm{C}$ storage belowground from various land cover types include particulate organic C (POC) and microbial biomass (MBC) (Wardle, 1992; Six et al., 1998; Wander, 2004). While direct measurements of $\mathrm{POC}$ and $\mathrm{MBC}$ are time-consuming and expensive, it is possible to approximate these soil $\mathrm{C}$ fractions through measures of the oxidizable C fraction (Culman et al. 2012). A greater soil microbial biomass is related to greater SOM long-term stabilization, through physical protection of microbial byproducts onto soil minerals (Cotrufo et al. 2013). In a larger context, it is unclear how shifts in dominant tree species may impact long-term SOM storage. Explicit values for decomposition rates of litter material from chestnut, relative to co-occurring tree species, have not yet been quantified, and the role of the tree-mediated soil microbial activity in this process is poorly understood. Here, we investigate how chestnut, with its incongruent properties of litter quality and ECM-associations, may influence fluxes of soil $\mathrm{C}$ and $\mathrm{N}$.

The purpose of this study was to examine the extent to which American chestnut differs from other co-occurring hardwood species in below-ground nutrient cycling processes, such as $\mathrm{N}$ 
mineralization, litter chemistry and decomposition, soil respiration, active $\mathrm{C}$ pools, and extracellular enzyme activity. I hypothesized that $\mathrm{N}$ mineralization would be lower in soil influenced by chestnut compared to oak or cherry, and that there would be increased $\mathrm{C}$ in soil as SOM, and lower rates of C loss through soil respiration, fitting within the ECM-AM framework of nutrient cycling. In addition, I hypothesized that chestnut litter would decompose more slowly and have higher tannin and recalcitrant compound content than oak or cherry litter. Lastly, I hypothesized that there would be lower extracellular enzyme activity in soils influenced by chestnuts than oak or cherry, due to the higher concentrations of tannins in chestnut litter inhibiting microbial activity and enzyme activity. I tested these hypotheses using a one-year laboratory soil incubation experiment with soil and litter collected from a plantation of American chestnut, black cherry and northern red oak plantation located within Purdue University's Martell Research Forest, West Lafayette, Indiana.

\section{Methods:}

Study Site:

The soil and litter samples for this study were collected at Purdue University's Martell Research Forest in West Lafayette, Indiana, USA $\left(40^{0} 26^{\prime} 42^{\prime \prime} \mathrm{N}, 87^{0} 01^{\prime} 47^{\prime \prime} \mathrm{W}\right)$. This 2.4 ha plantation of pure, non-hybrid American chestnut, along with two other commonly co-occurring species (Northern red oak, Quercus rubra, and Black cherry, Prunus serotina) were planted in 2007 to study chestnut growth (Gauthier et al, 2013). The plantation is comprised of seven species compositions; pure stands of each species, two-way mixes of each species, and a three-way mix of each species. This study utilized soil and litter collected from plots of the following species compositions: 
1) $100 \%$ black cherry,

2) $100 \%$ American chestnut,

3) $100 \%$ northern red oak,

The tree spacing regimes included in this study consisted of the $1 \times 1 \mathrm{~m}\left(10,000\right.$ stems ha $^{-1}, 5 \times 5 \mathrm{~m}$ plot size $)$ and $2 \times 2 \mathrm{~m}\left(2,500\right.$ stems $^{-1}, 10 \times 10 \mathrm{~m}$ plot size $)$ spacing, resulting in eight plots comprising an experimental block. This is replicated three times at the site ( 3 species mixes, 2 densities, 3 replications; $\mathrm{n}=6 ; \mathrm{N}=18$ ). An additional $3 \times 3$ meter stem density for each species combination existed as well, but was excluded due to high tree mortality.

Soils at the site are of the Rockfield type, which are mildly acidic to nearly neutral and consist mainly of silt loams with a clay content of approximately 20-32\% ("Rockfield Series” 2007). They are typically moderately productive, deep and formed from silty outwash and loamy till. Soil profiles were characterized at all three blocks and did not vary significantly, showing a 2-5 $\mathrm{cm}$ agriculturally disturbed Ap horizon, and weak Bt-horizon development. There are signs of an O-horizon beginning to develop, but at present there is no significant organic soil horizon. From 1981-2010, mean annual temperature was $10.4^{0} \mathrm{C}$, and mean annual precipitation was 970 mm (National Climatic Data Center, 2018).

Incubation core construction and sampling: 
The cores used for the incubations in this study were constructed from PVC (dimensions $20 \mathrm{~cm}$ tall $\mathrm{X} 9.28 \mathrm{~cm}$ diameter). Caps were fitted at the bottom, with a port opening so that leachate could drain through the soil medium for collection. Poly-fil material (approx. $2.5 \mathrm{~cm}$ ) was placed at the bottom of the core to prevent soil from clogging the fitting or exiting the core. To collect soils from the field plots, approximately $1 \mathrm{~kg}$ of soil was collected from the surface $5 \mathrm{~cm}$ from 10 randomized locations within one plot and composited. Soils were stored at $4^{0} \mathrm{C}$ for 2 months prior to analysis. Soil samples were then air-dried and sieved through a 2-mm mesh sieve to remove large pieces of organic matter and coarse fragments. A subsample from each plot was used to determine soil moisture by weighing before and after oven drying at $105^{\circ} \mathrm{C}$. The soil from each of the 18 study plots was then separated into 3 laboratory replicates to the equivalent of $200 \mathrm{~g}$ dry weight of soil ( $\mathrm{N}=54$ incubation units). The soil of each replicate was mixed with $160 \mathrm{~g}$ acid-washed paver's sand to promote greater hydraulic conductivity for leachate sampling and placed in the core. This design is based on previous incubation experiments to allow leachate to be sampled without disturbing the soil (Giardinia et al. 2001). $3.5 \mathrm{~g}$ dry-weight litter material from each plot (collected from plastic litter traps in October 2016 and composited) was added on top of the soil/sand mixture. Litter material was separated from the soil using $0.3 \mathrm{~mm}$ fiberglass screen to allow litter contact with the soil, but not mix with the soil, to allow for easier collection at the conclusion of the incubation. The soil-sand mixture and leaf litter were incubated for 1 year.

Repeated sample collection and measurements: 
Once per week, soils inside the cores were watered to field capacity with deionized (DI) water. Field capacity was calculated by adding water to the soil until it was seen flowing out of the fitting at the bottom of the core. The cores were then weighed, and field capacity was maintained by adding water to desired core weight in subsequent weeks of the experiment.

The incubation began December 2016. Every other week, the incubation cores were measured for soil respiration using a LI-COR 8100 IRGA chamber (LI-COR Biosiences, Lincoln, NE). The cores were watered to field capacity the day before measurements to ensure consistent soil moisture conditions for each measurement. The $\mathrm{CO}_{2}$ flux reported by the $\mathrm{Li}-\mathrm{COR}$ was converted into total $\mathrm{C}$ respired per unit area.

Once per month, $75 \mathrm{ml}$ of Hoagland's rainwater nutrient solution, modified to remove N, was added to the cores after watering to field capacity with DI water, with the exception of $\mathrm{T}=0$, where DI water was used in place of Hoagland's. By removing $\mathrm{N}$ from the rainwater solution, inorganic $\mathrm{N}$ within leachate could be used to accurately approximate $\mathrm{N}$ mineralization rates within the soil due to microbial activity. The cores were allowed to drain by gravity overnight. Typically, $75-80 \%$ of the original volume of solution was recovered. The leachate samples were split into two $20 \mathrm{ml}$ subsamples, one set analyzed for $\mathrm{DOC}$, and the second for $\mathrm{NO}_{3}$ and $\mathrm{NH}_{4}$ to measure $\mathrm{N}$ mineralization rates over time. These samples were stored frozen until analyzed. 
Dissolved organic C (DOC) samples were analyzed using a Shimadzu TOC analyzer (Shimadzu Scientific Instruments, Kyoto, Japan), and were run as composite samples of two time points to allow for adequate volume available for analysis. $\mathrm{NO}_{3}$ and $\mathrm{NH}_{4}$ were analyzed colorimetrically on a Synergy HTX plate reader (Biotek, Winooski, VT). $\mathrm{NO}_{3}$ samples were oxidized using vanadium chloride solutions and read at $549 \mathrm{~nm}$, while $\mathrm{NH}_{4}$ used sodium salicylate and bleach, and read at $650 \mathrm{~nm}$ (DeForest 2013). Samples were assayed with four replicates per sample in clear Corning (Corning, NY) 96-well plates. Concentrations were determined using dilution calibration curves of known lab $\mathrm{NH}_{4}$ and $\mathrm{NO}_{3}$ standards. DOC and $\mathrm{N}$ concentrations were converted into units of mass per $\mathrm{kg}$ of soil using volume of leachate collected and the mass of soil within the cores.

$T=1$ year measurements:

Upon completion of the incubation, leaf litter was dried at $65^{\circ} \mathrm{C}$ for 96 hours and reweighed to measure mass loss and decomposition rates. The soils were removed and stored at $4^{\circ} \mathrm{C}$ until ready for further analysis. First, a subsample of the soils was measured for enzyme activity using the colorimetric and fluorometric method adapted from Sinsabaugh et al. 2008. Enzymes measured in this analysis included acid phosphatase (AP), involved in breaking down phosphate esters, $\beta$-N-acetylglucosaminidase (NAG), which breaks down organic $\mathrm{N}$ compounds, $\beta$ glucosidase (BG), which convert cellulose into simple sugars, and phenol oxidase (PPO) and peroxidase (PER), which are involved in the decomposition of polyphenolics like lignin and tannins (Rosenberg 2010; Sinsabaugh et al. 2002). AP, NAG and BG activity was determined through fluorescence, while PPO and PER were determined colorimetrically. Soil was mixed in a slurry with sodium acetate buffer solution at a $\mathrm{pH}$ of 5.0, and pipetted into opaque Corning (Corning, NY) 96-well plate for fluorometric enzymes, and clear 96-well plates for PPO and 
PER, which are colorimetrically determined. Plates were arrayed with standards and controls. AP, NAG and BG used $100 \mu \mathrm{M}$ 4-methylumbelliferone (MUB) as a standard, and 4methylumbelliferyl phosphate, 4-methylumbelliferyl N-acetyl- $\beta$-D- glucosaminide and 4methylumbelliferyl $\beta$-glucopyranoside as substrates, respectively. Activity was determined through measuring fluorescence at $265 \mathrm{~nm}$ excitation and $460 \mathrm{~nm}$ emission on a Synergy HTX plate reader (Biotek, Winooski, VT). PPO and PER used $25 \mathrm{mM}$ 3,4-L- dihydroxyphenylalanine (L-DOPA) mixed with $50 \mathrm{mM}$ ethylenediaminetetraacetic acid disodium salt dihydrate (EDTA) as a substrate. Activity was determined by reading absorbance at $460 \mathrm{~nm}$ on the Synergy HTX plate reader. The ratio of BG (C activity) to NAG ( $\mathrm{N}$ activity) was calculated for each core and used to determine the relative proportion of resource allocation to acquiring $\mathrm{C}$ and $\mathrm{N}$ for each species (Knelman et al. 2017).

A second subsample from each core was used to determine total oxidizable $\mathrm{C}$ using the permanganate method (Culman et al. 2012). Permanganate oxidizable C (POXC) is typically used as proxy for total biologically active $\mathrm{C}$, including particulate organic $\mathrm{C}$, microbial biomass $\mathrm{C}$, and SOC, and is a useful way to determine differences in C sequestration among different soils or treatments (Culman et al. 2012). Subsamples were air-dried, and added to a solution with $0.2 \mathrm{M} \mathrm{KMnO}_{4}$ (permanganate). The soil-permanganate solutions were shaken for 2 minutes at $120 \mathrm{rpm}$ and allowed to settle for 10 minutes. The supernatant was pipetted onto a clear Corning (Corning, NY) 96-well plate, along with permanganate standards and DI blanks, and absorbance was read at $550 \mathrm{~nm}$ to determine proportion of $\mathrm{C}$ oxidized by the permanganate. 
The leaf litter removed from the cores was ground in a Wiley-mill grinder and used to determine acid insoluble compounds and polyphenolic tannin content. Acid insoluble and recalcitrant compound content of the leaf litter was determined using a slightly modified version of the Klasson acid digestion method adapted for use with leaf litter (Ibáñez \& Bauer 2014). Two replicates per sample of $300 \mathrm{mg}$ of ground, oven-dried litter was digested in $8 \mathrm{ml}$ of cold (12$\left.15{ }^{\circ} \mathrm{C}\right) 72 \% \mathrm{H}_{2} \mathrm{SO}_{4}$ for two hours at room temperature, diluted to $3 \%$ using $22 \mathrm{ml}$ of DI water and autoclaved at $121^{\circ} \mathrm{C}$ for one hour. Samples were cooled at $4^{\circ} \mathrm{C}$ overnight and filtered through a ceramic crucible of known mass to separate soluble lignin and insoluble compound fractions. A 10-ml aliquot of the filtrate was saved to measure the soluble lignin fraction. The crucibles were washed free of acid; oven-dried for 16 hours at $105^{\circ} \mathrm{C}$, and allowed to cool in a desiccator. The soluble fraction was measured at 280 and $215 \mathrm{~nm}$ with a Synergy HTX plate reader (Biotek, Winooski, VT), and was calculated by the following formula: $\mathrm{S}=\left(\left(4.53 * \mathrm{~A}_{215}\right)-\right.$ $\left.\mathrm{A}_{280}\right)$ )/300, where $\mathrm{S}$ is the concentration of soluble lignin, $\mathrm{A}_{215}$ is the absorbance at $215 \mathrm{~nm}$, and $\mathrm{A}_{280}$ is the absorbance at $280 \mathrm{~nm}$ (Moreira-Vilar et al. 2014). Total recalcitrant compounds were measured as the sum of insoluble material that could not pass through the crucible and soluble lignin in the supernatant. Proportion of soluble lignin and insoluble compounds lost during the incubation period was calculated by subtracting concentration of each sample from the mean value of composited non-decayed litter by spacing and species treatment.

The tannin content of the litter was determined using the proanthocyanidin (PA) methanol-acid assay (Preston et al. 1997, Preston 1999), slightly modified for use with ground litter (Lorenz et al. 2000). $5 \%$ volumetric concentrated $\mathrm{HCl}$ in $n$-butanol, with a total water content of $5 \% \mathrm{v} / \mathrm{v}$ and $200 \mathrm{mg} / \mathrm{l}$ of $\mathrm{FeSO}_{4} * 7 \mathrm{H}_{2} \mathrm{O}$ was prepared fresh each day during the analysis. A proanthocyanidin 
standard solution was prepared using pycnogenol derived from pine bark (Chen \& Sang 2014) diluted with methanol. $25 \mathrm{mg}$ of ground litter were weighed into $50 \mathrm{ml}$ centrifuge tubes. After adding $20 \mathrm{ml}$ of acetone ( $70 \%$ by volume) the tubes were shaken for $1.5 \mathrm{~h}$, and centrifuged at $7000 \mathrm{rpm}$ for $20 \mathrm{~min}$. The supernatant was then poured into $50 \mathrm{ml}$ volumetric flasks. This process was repeated, and the supernatants combined and brought up to $50 \mathrm{ml}$ total volume per sample using the acetone solution. Next, $2 \mathrm{ml}$ of the supernatant were transferred into test tubes, and air-dried inside a fume hood, along with the pellets of remaining insoluble residue within the centrifuge tubes. Upon drying, $5 \mathrm{ml}$ of the $\mathrm{FeSO}_{4}$ solution was added to all samples, vortexed, and left in a $95^{\circ} \mathrm{C}$ hot water bath for 1.5 hours, and allowed to cool. $300 \mu$ l of solution for each sample was transferred to Corning (Corning, NY) 96-well, clear plates along with methanol blanks, and tannin standards. Absorbance was recorded at $550 \mathrm{~nm}$ on the plate reader. Total tannin content of the litter was the sum of residual tannins from the residue samples and the extractable tannins from the supernatant samples. Tannin degradation during the incubation period was calculated by subtracting tannin content of each sample from the mean value of composited non-decayed litter by Spacing and Species treatment.

\section{Data analysis:}

For each variable measured (Nmin, DOC, soil respiration, POXC, enzyme activity, bulk C and $\mathrm{N}$, litter decomposition, litter acid insoluble compounds and litter, and tannin), data were compiled and statistically analyzed using version 13.0 of JMP software. Model effects for the statistical analysis were spacing and species composition, with the two-way interaction term serving as the experimental unit. Three laboratory replicates were used to estimate means for

each experimental unit. Residuals were first checked for normality using the Shapiro-Wilke test. If the data for a measurement deviated from normality, a transformation was applied to conform 
to the assumption of normality required for ANOVA tests. Multiple ANOVAs were used to test for significant differences in mean values of each data set between block, spacing, horizon and species, along with full factorial interactions. Tukey-Kramer HSD tests were used as a post-hoc analysis for comparisons between significant model effects.

Pairwise correlations were run on litter mass loss and $\mathrm{N}$ mineralization and potential explanatory variables, such as acid insoluble compounds and tannin concentrations and losses for litter decomposition, and BG:NAG activity for $\mathrm{N}$ mineralization to examine potential drivers of different rates of litter loss and $\mathrm{N}$ mineralization between species. Lastly, a principal component analysis (PCA) was performed to further explore which parameters were most influentially affecting litter decomposition rates. Two principal components (PC) were calculated from litter quality measurements, soil chemistry measurements and enzyme activity were calculated. For each set of PCAs, eigenvalues of both PC's were calculated to determine the variance explained by the PCA, and plotted against one another to evaluate separation between species. For components that had separation between species, the PC with the highest eigenvalue was plotted against litter decomposition and fitted with linear regression to test if the components were related to litter decomposition.

\section{Results}

Soil Respiration, Nitrogen Mineralization and DOC: 
Cumulative $\mathrm{C}$ loss through respiration during the one-year incubation was not significantly different between species $(\mathrm{p}=0.4699$; Figure 3.1). However, the spacing treatments did have a differential effect on $\mathrm{C}$ respired $(\mathrm{p}=0.0081$ ), with the cumulative mean $\mathrm{C}$ respired for $1 \mathrm{~m}$ spacing ( $\left.258.87 \mathrm{~g} \mathrm{C} / \mathrm{m}^{2}\right)$ lower than the $2 \mathrm{~m}$ treatment $\left(298.42 \mathrm{~g} \mathrm{C} / \mathrm{m}^{2}\right)$. In addition, the model interaction term was significant. While species was not a significant effect on its own, the effect that species had on respiration rates did depend on the spacing of the trees $(p=0.0075)$, with the $2 \mathrm{~m}$ treatment having greater respiration than the $1 \mathrm{~m}$ treatment in cherry and oak cores, but not in chestnut cores.

Cumulative $\mathrm{N}$ mineralization rates required a Log transformation to adhere to ANOVA's assumption of normality. The rate of $\mathrm{N}$ mineralization was significantly affected by tree species $(\mathrm{p}=0.0178)$. $\mathrm{N}$ mineralization from chestnut cores $\left(7.84 \mathrm{mg} \mathrm{N} \mathrm{kg}^{-1}\right.$ soil $)$ was significantly lower than cores containing cherry litter and soil (11.51 mg N/ kg-1 soil) and oak litter and soil (12.00 $\mathrm{mg} \mathrm{N} \mathrm{kg}^{-1}$ soil) (Figure 3.2). Spacing and the interaction of species and spacing were not significant.

DOC collected from leachate was significantly different by tree species $(p=0.0137)$. DOC from chestnut cores (31.38 mg DOC kg ${ }^{-1}$ soil) was significantly greater than DOC from oak cores (26.39 mg DOC kg-1 soil), though DOC from cherry cores (29.71 $\mathrm{mg} \mathrm{DOC} \mathrm{kg}^{-1}$ soil) was not significantly different from either (Figure 3.3). DOC collected in leachate did not vary by spacing and did not have any significant model effect interactions. 
$T=1$-year Measurements:

While not statistically significant $(\mathrm{p}=0.1840)$, mean POXC from chestnut cores $(284.50 \mathrm{mg} \mathrm{C}$ $\mathrm{kg}^{-1}$ soil) was greater than POXC from cherry cores (230.66 $\mathrm{mg} \mathrm{C} \mathrm{kg}^{-1}$ soil) and oak cores (253.53 $\mathrm{mg} \mathrm{C} \mathrm{kg}^{-1}$ soil). Spacing and the interaction of spacing upon species were not significant either (Figure 3.4).

Enzyme activity and significant model effects were different for each enzyme measured (Table 3.1). AP activity was dependent upon species $(\mathrm{p}=0.0045)$, with chestnut $\left(4.94 \mathrm{mmol} \mathrm{h}^{-1} \mathrm{~g}^{-1}\right)$ and oak $\left(5.48 \mathrm{mmol} \mathrm{h}^{-1} \mathrm{~g}^{-1}\right)$ coress containing significantly higher AP activity than cherry (3.55 $\mathrm{mmol} \mathrm{h}^{-1} \mathrm{~g}^{-1}$ ) (Figure 3.5). In addition, the effect of species on mean AP activity varied by spacing treatment $(\mathrm{p}=0.0169)$, with the $2 \mathrm{~m}$ chestnut cores containing greater AP activity than $1 \mathrm{~m}$ chestnut cores and both 12 and $2 \mathrm{~m}$ cherry cores. Mean PER activity required the removal of 2 outliers and a Log transformation to conform to normality, and was not dependent upon species $(\mathrm{p}=0.1523)($ Figure 3.5), but was dependent upon spacing $(\mathrm{p}=0.0076)$, with the mean backtransformed PER activity of the $1 \mathrm{~m}$ treatment $\left(0.65 \mathrm{mmol} \mathrm{h}^{-1} \mathrm{~g}^{-1}\right)$ significantly greater than that of the $2 \mathrm{~m}$ treatment $\left(0.34 \mathrm{mmol} \mathrm{h}^{-1} \mathrm{~g}^{-1}\right)$. Lastly, mean PPO activity required the removal of one outlier and a Log transformation as well, was dependent upon spacing $(\mathrm{p}=0.0002)$, but not species $(\mathrm{p}=0.1778)$, with the back-transformed mean of the $1 \mathrm{~m}$ treatment $\left(0.56 \mathrm{mmol} \mathrm{h}^{-1} \mathrm{~g}^{-1}\right)$ greater than that of the $2 \mathrm{~m}$ treatment $\left(0.21 \mathrm{mmol} \mathrm{h}^{-1} \mathrm{~g}^{-1}\right)$ (Figure 3.5).

BG:NAG ratio, which shows the ratio of investments towards enzymes related to $\mathrm{C}$ and $\mathrm{N}$ acquisition, was significantly affected by tree species ( $\mathrm{p}<0.0001$ ). BG:NAG ratio was calculated 
using the raw BG and NAG activity data, and required the removal of two outliers and a log transformation to conform to the assumption of normality. The back-transformed mean BG:NAG ratio of chestnut (7.87) and oak (10.66) were significantly lower than that of cherry (15.70) (Figure 3.6). Spacing differentially affected mean BG:NAG ratio as well $(p=0.0109)$, with the BG:NAG ratio of the $2 \mathrm{~m}$ treatment (12.55) greater than that of the $1 \mathrm{~m}$ treatment $(10.23)$.

The decomposition rate of litter was dependent upon species $(\mathrm{p}<0.0001)$, with mean chestnut litter mass loss $(18.97 \%)$ significantly greater than both oak litter mass loss $(10.83 \%)$ and cherry litter mass loss (14.18\%) (Figure 3.7). Spacing and the interaction of spacing and species were not significant. Litter $\mathrm{C}: \mathrm{N}$ ratio after one year of decomposition was dependent upon species as well ( $\mathrm{p}<0.0001)$, with chestnut litter C:N (36.04) significantly greater than oak litter (27.03) and cherry litter (28.83). In addition, the effect of species upon litter C:N was dependent upon spacing $(\mathrm{p}=0.0001)$, with the $\mathrm{C}: \mathrm{N}$ ratio of chestnut litter from the $1 \mathrm{~m}$ spacing treatment greater than that of the litter from all other spacing and species combinations, and the $2 \mathrm{~m}$ chestnut litter greater than the $1 \mathrm{~m}$ oak litter.

The concentration of acid insoluble compounds within leaf litter was also dependent upon species $(\mathrm{p}<0.0001)$, with mean acid insoluble compound and soluble lignin concentration of chestnut litter (42.97\%) significantly lower than oak litter (46.89\%), and significantly lower than cherry concentration (52.86\%) (Figure 3.8). In addition, the effect of species upon acid insoluble compound concentration was dependent upon spacing treatment $(\mathrm{p}=0.0158)$. Insoluble compound loss by mass over time during the incubation was also dependent upon 
species ( $\mathrm{p}<0.0001)$, with \% loss in chestnut litter $(13.59 \%)$ and oak litter $(10.86 \%)$

significantly greater than loss by cherry litter (2.32\%) (Figure 3.8). The effect of species upon insoluble compound and soluble lignin loss was also dependent upon spacing $(\mathrm{p}=<0.0001)$.

Tannin concentration of leaf litter after one year was dependent required a Log transformation to conform to the assumption of normality, and was dependent upon species $(\mathrm{p}<0.0001)$. The back-transformed mean tannin concentration of chestnut litter (6.70\%) and oak litter (5.67\%) significantly lower than cherry tannin concentration (10.78\%) (Figure 3.9). In addition, \% tannin loss by mass during the incubation also required a Log transformation, and was dependent upon species $(\mathrm{p}<0.0001)$, with $\%$ tannin loss of chestnut litter $(1.76 \%)$ significantly lower than oak litter $(10.34 \%)$, and significantly lower than tannin loss by cherry litter (17.86\%) (Figure 3.9). Tannin loss was also dependent upon the Spacing treatment $(\mathrm{p}<0.0001)$, as well as the two-way interactions of Block and Spacing treatments $(\mathrm{p}=0.123)$, Block and Species treatments $(\mathrm{p}=0.0244)$, Spacing and Species treatments $(\mathrm{p}=0.0012)$, and the three-way interaction of Block, Spacing and Species $(\mathrm{p}<0.0001)$.

Litter mass loss was negatively correlated with tannin loss in leaf litter during the incubation period $(\mathrm{r}=-0.2824, \mathrm{p}=0.0385)$, but was not correlated to the concentration of acid insoluble compounds and acid soluble lignin $(r=-0.1734, \mathrm{p}=0.2189)$ or $\operatorname{tannin}(\mathrm{r}=0.0872, \mathrm{p}=0.5306)$ in litter upon completion of the incubation, or insoluble compounds and acid soluble lignin loss during the incubation period $(\mathrm{r}=0.0379, \mathrm{p}=0.7899)$ (Figure 3.10). $\mathrm{N}$ mineralization was negatively correlated to litter mass loss $(r=-0.4014, \mathrm{p}=0.0026)$ and DOC concentration in 
leachate $(\mathrm{r}=-0.3171, \mathrm{p}=0.0195)$, but was not correlated with NAG activity $(\mathrm{r}=-0.2476, \mathrm{p}=$ 0.0739), or change in litter tannin concentration $(\mathrm{r}=0.1856, \mathrm{p}=0.1790)$ (Figure 3.11).

Results from the PCA indicate that including all variables measured during the incubation (including all soil, litter, and enzyme parameters) explained 52.7\% (PC1 = 31.3\%; PC2 = 21.4\%) of the variation in litter decomposition. In addition, a PCA was also performed on soil enzyme activity measurements, litter chemistry measurements and soil chemistry measurements. The enzyme PCA (AP, PER, PPO, BG:NAG) explained 64.3\% (PC1 = 39.8\%, PC2 = 24.5\%). The litter chemistry PCA (Initial \& $\mathrm{T}=1$ year tannin concentration; tannin loss; initial \& $\mathrm{T}=1$ year recalcitrant compound concentration; recalcitrant compound loss; $\mathrm{T}=1$ year $\mathrm{C} \& \mathrm{~N}$ content; initial and $\mathrm{T}=1$ year $\mathrm{C}: \mathrm{N})$ explained $74.3 \%(\mathrm{PC} 1=47.2 \%, \mathrm{PC} 2=27.1 \%)$ of variation. Lastly, the PCA using soil parameters ( $\mathrm{N}$ mineralization; DOC; POXC; soil respiration) explained $65.1 \%(\mathrm{PC} 1=39.4 \%, \mathrm{PC} 2=25.7 \%)$ of variation (Table 3.2$)$. In addition, when litter quality PC1 is plotted against PC2, a clear separation by species is evident (Figure 3.12). Linear regression of litter quality PC1 and litter decomposition indicates that litter quality PC1was significantly related to litter decomposition rates $\left(\mathrm{R}^{2}=0.1835, \mathrm{p}=0.0015\right)$. (Figure 3.12). PC1 of soil chemistry parameters and all variables were also significantly related to litter decomposition rates by linear regression, but did not exhibit clear separation of tree species when PC1 is plotted against PC2 (Table 3.2). 


\section{Discussion}

Generally, relative to the co-occurring tree species, American chestnut has differentially influenced the soil $\mathrm{C}$ and $\mathrm{N}$ dynamics compared to oak and cherry after less than 10 years of growth on this site. From the lab incubation study, chestnut soil and litter produced significantly more DOC in leachate than oak soil and litter, and a non-significant trend in greater DOC than cherry (Figure 3.3). Greater DOC in soil typically represents lower microbial C demand to due limitation of $\mathrm{N}$, as mineralization of $\mathrm{C}$ is dependent upon energy demand (Aber 1992; McDowell et al. 1998). The relative difference in DOC between chestnut and cherry from this study align with those of a study in Moore's Creek, Indiana, USA that found $0.64 \mathrm{mg} \mathrm{DOC} \mathrm{g}^{-1}$ in soil influenced by ECM trees compared to $0.32 \mathrm{mg} \mathrm{DOC} \mathrm{g}^{-1}$ in AM-dominated soil (Phillips et al. 2013).

In addition, there was also a trend of greater POXC in chestnut cores than oak or cherry cores, and while non-significant, chestnut core soils on average contained $23 \%$ more POXC than cherry and $12 \%$ higher than oak soils (Figure 3.4), and are similar to differences seen between deciduous species in plantations in the Huitong National Research Station of Forest Ecosystem, in the Hunan providence of China (Wang et al. 2013). In past studies, POXC has been found to be most strongly related to heavier and smaller POC fractions, indicating it reflects a heavily processed, stable pool of $\mathrm{C}$ found in SOM, and is therefore a suitable parameter for predicting long-term soil C sequestration (Culman et al. 2012). Therefore, while non-significant, this trend of greater POXC in soils influenced by American chestnut may indicate potential for long-term 
stable C storage in soil. However, the oak cores do not follow this trend, with no differences in POXC in soil or DOC in leachate relative to cherry, despite its ECM association.

Importantly, there was no significant species effect on $\mathrm{C}$ loss from soils through respiration. While respiration from chestnut cores was not lower than oak or cherry cores as hypothesized, the lack of species effect may indicate that the additional DOC and POXC in chestnut soils was not quickly lost and may be available for long-term storage on soil mineral surfaces. These data support the hypothesis that the influence of chestnut would lead to greater SOM accumulation than oak or cherry, and aligns with models that predict greater $\mathrm{C}$ storage and lesser $\mathrm{C}$ turnover below ground by ECM-associated trees (Averill et al. 2014; Taylor et al. 2016). The lack of significant difference in respiration is not unusual, as previous studies on $\mathrm{C}$ cycling of European hardwood species have found oak and sugar maple both had respiration fluxes of $1.69 \mu \mathrm{mol} \mathrm{m}{ }^{-2}$ $\mathrm{s}^{-1}$, while beech was significantly lower than both at $1.27 \mu \mathrm{mol} \mathrm{m}^{-2} \mathrm{~s}^{-1}$ (Vesterdal et al. 2012).

Chestnut cores also lost significantly less mineral $\mathrm{N}$ than oak or cherry cores, which supports the hypothesis that soils influenced by chestnut would have lower $\mathrm{N}$ mineralization rate. However, because tannin concentrations in chestnut leaf litter were not higher than that of the other study species, the mechanism driving this is not clear. This also fits into mycorrhizal-mediated $\mathrm{C}$ and $\mathrm{N}$ cycling model that predict greater soil $\mathrm{C}$ and lower $\mathrm{N}$ in ECM trees compared to AM Averill et al. 2014; Taylor et al. 2016). Although the lack of difference in $\mathrm{N}$ mineralization between oak and cherry does not match this proposed model, the difference between chestnut and cherry follows a similar pattern to a study in Harvard Forest, MA, USA that found much higher N mineralization rates of both bulk and rhizosphere soil influenced by sugar maple (Acer 
saccharum) than the ECM species American beech (Fagus grandifolia) (Brzostek et al. 2013). In the present study, $\mathrm{N}$ mineralization rates were also negatively correlated with both litter decomposition rates and DOC content (Figure 3.11). The relationship between DOC and N mineralization in soil is well established, and is thought to be due to microbial energy constraints (Aber 1992; McDowell et al. 1998). This indicates that the lack of inorganic $\mathrm{N}$ in chestnutdominated soils reduces the demand for $\mathrm{C}$ uptake by microbes, reducing $\mathrm{C}$ mineralization.

Chestnut leaf litter in the cores had greater mass loss over the incubation period and contained less lignin an acid insoluble compounds after one year than oak or cherry litter, and contained less tannins after one year than cherry litter. This does not support my hypothesis that chestnut litter would be slower to decompose and contain higher concentrations of recalcitrant compounds. This also does not explain why $\mathrm{N}$ mineralization was lower in chestnut soil, as tannins are capable of binding enzymes and proteins, slowing $\mathrm{N}$ mineralization (Hagerman \& Butler, 1981; Hättenschwiler \& Vitousek, 2000). However, it would explain the higher levels of DOC and POXC accumulating in the chestnut cores, as more $\mathrm{C}$ would enter the soil as the leaf litter decays, and the lack of mineral $\mathrm{N}$ would reduce $\mathrm{C}$ mineralization. In addition, the $\mathrm{HCl}-$ Butanol method, while commonly used for measuring proanthocyanidins or condensed tannins, may not be the best measure of tannins that affect microbial decomposition (Lovett et al. 2004). Previous studies have reported positive correlations between less-polymerized tannin concentrations and microbial activity (Schimel et al. 1998; Fierer et al. 2001). It is therefore possible that while chestnut litter may contain less total PAs than cherry litter, the fraction that inhibits microbial activity and $\mathrm{N}$ mineralization, likely longer-chain tannins, may be present, but cannot be differentiated by the $\mathrm{HCl}$ - Butanol method. 
In previous studies, litter decomposition has been found to be more closely correlated to latestage litter quality than initial quality (Giardina et al. 2001). Therefore, evaluating change in lignin and acid insoluble compound and tannin concentrations over time may help explain drivers of decomposition more than initial values. While more acid insoluble compounds and lignin was lost by $\%$ mass from chestnut litter, concentrations after one year and loss during incubation was not correlated to litter decomposition. However, change in tannin composition of litter was negatively correlated to litter decomposition. As more tannins were lost from the oak and cherry litter, it is possible the greater flux of tannins entering the soil inhibited the further decomposition of the leaf litter material. This provides a possible explanation of the processes leading to the higher decomposition rate of chestnut litter. The PCA revealed that while both soil and litter chemistry variables, along with all variables measured during the incubation combined were significantly related to litter decomposition rates by linear regression, only litter chemistry showed any separation by species when plotting both principal components. This indicates that the differences in litter chemistry between species was indeed the factor driving litter decomposition rates.

Enzyme activity results indicate that chestnut soils have greater AP activity than cherry, and significantly lower PER activity than cherry, and non-significantly lower PER than oak and PPO than oak and cherry. This, coupled with chestnut litter not containing greater concentrations of tannins compared to oak or cherry, does not completely support the hypothesis that chestnut soils would have lower overall enzyme activity than both oak and cherry resulting from increased 
concentrations of tannins inhibiting enzyme activity. However, chestnut and oak having greater AP activity may be due to ECM fungi having the ability to release AP enzymes, whereas in AM species, they are normally released by roots and free-living microbes (Phillips \& Fahey 2006). There were no roots present in the incubation cores, but free-living microbes may have been present, this may explain this result. Chestnut soil PPO activity was significantly lower than that of cherry, and although not significantly separate from oak soil PPO activity, it was 37\% lower. In addition, although species was not a significant effect on PER activity, chestnut soils ( 0.354 $\left.\mathrm{mmol} \mathrm{h}^{-1} \mathrm{~g}^{-1}\right)$ was $40 \%$ lower than cherry $\left(0.592 \mathrm{mmol} \mathrm{h}^{-1} \mathrm{~g}^{-1}\right)$ and $37 \%$ lower than oak $(0.558$ $\mathrm{mmol} \mathrm{h}^{-1} \mathrm{~g}^{-1}$ ) activity. This may support the possibility that although chestnut litter contained lower total proanthocyanidins than oak or cherry litter both initially and after 1 year, more of the enzyme-inhibiting fraction may have been present. Both PPO and PER are involved in the degradation of lignin, and although chestnut litter lost more insoluble compounds and lignin by percent mass than oak or cherry, expressed enzyme activity related to the decomposition of lignin was lower in chestnut soils, possibly indicating that enzyme activity was inhibited through sorption onto the complex compounds.

The ratio of BG:NAG activity of chestnut soils was significantly lower than that of both oak and cherry soils. This indicates that the microbial community was more $\mathrm{N}$ limited in the chestnut soils, and were investing in producing more NAG enzymes to acquire what $\mathrm{N}$ they could. Typically, under N-limited conditions, the $\mathrm{C}$ use efficiency (CUE) of microbial communities will decrease, and will respire more $\mathrm{C}$ per unit $\mathrm{N}$ acquired in an effort to get what little $\mathrm{N}$ is available. However, an increase in respiration in chestnut soils was not evident relative to oak or cherry soils, indicating that the microbial communities associated with chestnut soils have a greater 
CUE and the extracellular enzymes in chestnut soils break down more N-containing compounds (NAG) relative to the production of simple sugars (BG), and is C-efficient in acquiring $\mathrm{N}$ (i.e. has a high $\mathrm{N}$ use efficiency (NUE)). This aligns well with the relatively low $\mathrm{N}$ mineralization, high DOC, and moderate respiration from chestnut, as the microbial community associated with chestnut are efficient to get enough $\mathrm{N}$ while not increasing $\mathrm{C}$ loss through respiration, allowing for the production of greater DOC leached from chestnut soils (rapid decomposition, low $\mathrm{N}$ mineralization $=$ high NUE).

\section{Conclusion}

This study indicates that soils influenced by American chestnut had lower $\mathrm{N}$ mineralization compared to oak and cherry, and resulted in an accumulation of the DOC and oxidizable C pools related to microbial biomass and SOM accumulation. This cannot fully be explained by litter quality as chestnut litter did not contain significantly greater amounts of recalcitrant and nutrient cycling inhibiting compounds as hypothesized, though the PCA analysis indicates clear separation of litter quality parameters by species and a significant correlation to litter decomposition. In addition, the microbial community within soils influenced by chestnut litter is efficient in its use of $\mathrm{C}$ to acquire $\mathrm{N}$ (high NUE), resulting in no increase of $\mathrm{C}$ loss through respiration compared to oak or cherry. Overall, the soil ecosystem from chestnut plots has an accumulating microbial biomass with high $\mathrm{N}$ use efficiency (NUE), reflective of greater SOM accumulation potential relative to co-occurring tree species black cherry and red oak. This pattern did not vary by spacing treatment, indicating this may be seen in a variety of conditions. These results indicate that greater fluxes of inorganic $\mathrm{N}$ may have been occurred from forested 
ecosystems as chestnut declined, and has positive implications for $\mathrm{C}$ storage belowground if chestnut is successfully reintroduced throughout its native range. 


\section{Literature Cited}

Aber, J. D. (1992). Nitrogen cycling and nitrogen saturation in temperate forest ecosystems. Trends in Ecology \& Evolution, 7(7), 220-224.

Batjes, N. H. (2014). Total carbon and nitrogen in the soils of the world. European Journal of Soil Science, 65(1), 10-21.

Brzostek, E. R., Greco, A., Drake, J. E., \& Finzi, A. C. (2013). Root carbon inputs to the rhizosphere stimulate extracellular enzyme activity and increase nitrogen availability in temperate forest soils. Biogeochemistry, 115(1-3), 65-76.

Chen, H., \& Sang, S. (2014). Biotransformation of tea polyphenols by gut microbiota. Journal of Functional Foods, 7, 26-42.

Cotrufo, M. F., Wallenstein, M. D., Boot, C. M., Denef, K. \&amp; Paul, E. (2013). The Microbial Efficiency-Matrix Stabilization (MEMS) framework integrates plant litter decomposition with soil organic matter stabilization: do labile plant inputs form stable soil organic matter?. Global Change Biology, 19(4), 988-995.

Craig, M. E., Turner, B. L., Liang, C., Clay, K., Johnson, D. J., \& Phillips, R. P. (2018). Tree mycorrhizal type predicts within-site variability in the storage and distribution of soil organic matter. Global change biology.

Culman, S. W., Snapp, S. S., Freeman, M. A., Schipanski, M. E., Beniston, J., Lal, R. ... \& Lee, J. (2012). Permanganate oxidizable carbon reflects a processed soil fraction that is sensitive to management. Soil Science Society of America Journal, 76(2), 494-504.

DeForest, J. L. (2013). Optimized Lab Protocols for Testing Soils. Department of Environmental and Plant Biology. Ohio University. Athens, OH.

Ellison, A. M., Bank, M. S., Clinton, B. D., Colburn, E. A., Elliott, K., Ford, C. R., ... \& Mohan, J. (2005). Loss of foundation species: consequences for the structure and dynamics of forested ecosystems. Frontiers in Ecology and the Environment, 3(9), 479-486.

Fierer, N., Schimel, J. P., Cates, R. G., \& Zou, J. (2001). Influence of balsam poplar tannin fractions on carbon and nitrogen dynamics in Alaskan taiga floodplain soils. Soil Biology and Biochemistry, 33(12-13), 1827-1839.

Finzi, A. C., Van Breemen, N., \& Canham, C. D. (1998). Canopy tree-soil interactions within temperate forests: species effects on soil carbon and nitrogen. Ecological applications, 8(2), 440446. 
Giardina, C. P., Ryan, M. G., Hubbard, R. M., \& Binkley, D. (2001). Tree species and soil textural controls on carbon and nitrogen mineralization rates. Soil Science Society of America Journal, 65(4), 1272-1279.

Hagerman, A. E., \& Butler, L. G. (1981). The specificity of proanthocyanidin-protein interactions. Journal of Biological Chemistry, 256(9), 4494-4497.

Hättenschwiler, S., \& Vitousek, P. M. (2000). The role of polyphenols in terrestrial ecosystem nutrient cycling. Trends in ecology \& evolution, 15(6), 238-243.

Ibáñez, A. B., \& Bauer, S. (2014). Downscaled method using glass microfiber filters for the determination of Klason lignin and structural carbohydrates. Biomass and Bioenergy, 68, 75-81.

Knelman, J. E., Graham, E. B., Ferrenberg, S., Lecoeuvre, A., Labrado, A., Darcy, J. L., ... \& Schmidt, S. K. (2017). Rapid Shifts in Soil Nutrients and Decomposition Enzyme Activity in Early Succession Following Forest Fire. Forests, 8(9), 347.

Kogel-Knabner, I., Guggenberger, G., Kleber, M., Kandeler, E., Kalbitz, K., et al. (2008). Organo-mineral associations in temperate soils: Integrating biology, mineralogy, and organic matter chemistry. Journal of Plant Nutrition and Soil Science .171(1), 61-82.

Lin, G., McCormack, M. L., Ma, C. and Guo, D. (2017), Similar below-ground carbon cycling dynamics but contrasting modes of nitrogen cycling between arbuscular mycorrhizal and ectomycorrhizal forests. New Phytol, 213: 1440-1451.

Lorenz, K., Preston, C. M., Raspe, S., Morrison, I. K., \& Feger, K. H. (2000). Litter decomposition and humus characteristics in Canadian and German spruce ecosystems: information from tannin analysis and 13C CPMAS NMR. Soil Biology and Biochemistry, 32(6), 779-792.

Lovett, G. M., Weathers, K. C., \& Arthur, M. A. (2002). Control of Nitrogen Loss from Forested Watersheds by Soil Carbon: Nitrogen Ratio and Tree Species Composition. Ecosystems, 5(7), 0712-0718.

Lovett, G. M., Weathers, K. C., Arthur, M. A., \& Schultz, J. C. (2004). Nitrogen cycling in a northern hardwood forest: do species matter? Biogeochemistry, 67(3), 289-308.

McDowell, W. H., Currie, W. S., Aber, J. D., \& Yang, Y. (1998). Effects of chronic nitrogen amendments on production of dissolved organic carbon and nitrogen in forest soils. In Biogeochemical Investigations at Watershed, Landscape, and Regional Scales (pp. 175-182). Springer, Dordrecht.

Moreira-Vilar, F. C., de Cássia Siqueira-Soares, R., Finger-Teixeira, A., de Oliveira, D. M., Ferro, A. P., da Rocha, G. J., ... \& Ferrarese-Filho, O. (2014). The acetyl bromide method is faster, simpler and presents best recovery of lignin in different herbaceous tissues than klason and thioglycolic acid methods. PLoS One, 9(10), e110000. 
Phillips, R. P., Brzostek, E., \& Midgley, M. G. (2013). The mycorrhizal-associated nutrient economy: a new framework for predicting carbon-nutrient couplings in temperate forests. New Phytologist, 199(1), 41-51.

Phillips, R. P., \& Fahey, T. J. (2006). Tree species and mycorrhizal associations influence the magnitude of rhizosphere effects. Ecology, 87(5), 1302-1313.

Preston, C.M., 1999. Condensed tannins of salal (Gaultheria Shallon Pursh): a contributing factor to seedling 'growth-check' on Northern Vancouver Island? In: Gross, G.G., Hemingway, R.W., Yoshida, T. (Eds.), Plant Polyphenols: Chemistry and Biology. Plenum Press, New York, in press.

Preston, C.M., Trofymow, J.A., Sayer, B.G., Niu, J., 1997. 13C nuclear magnetic resonance spectroscopy with cross-polarization and magic-angle spinning investigation of the proximate analysis fractions used to assess litter quality in decomposition studies. Canadian Journal of Botany 75, 1601 \pm 1613 .

Rhoades, C. C. (2007). The influence of American Chestnut (Castanea dentata) on nitrogen availability, organic matter and chemistry of silty and sandy loam soils. Pedobiologia, 50(6), 553-562.

Rosenberg, C. (2010). Foliar Chemical Analysis, Decomposition, and Effects on Nutrient Cycling of American Chestnut and its Hybrids (MS Thesis). Retrieved from https://etd.ohiolink.edu/rws_etd/document/get/ohiou1276875529/inline

Ruffo, M. L., \& Bollero, G. A. (2003). Residue decomposition and prediction of carbon and nitrogen release rates based on biochemical fractions using principal-component regression. Agronomy Journal, 95(4), 1034-1040.

Schimel, J. P., Cates, R. G., \& Ruess, R. (1998). The role of balsam poplar secondary chemicals in controlling soil nutrient dynamics through succession in the Alaskan taiga. Biogeochemistry, 42(1-2), 221-234.

Schulp, C. J., Nabuurs, G. J., Verburg, P. H., \& de Waal, R. W. (2008). Effect of tree species on carbon stocks in forest floor and mineral soil and implications for soil carbon inventories. Forest ecology and management, 256(3), 482-490.

Sinsabaugh, R. L., Carreiro, M. M., \& Repert, D. A. (2002). Allocation of extracellular enzymatic activity in relation to litter composition, $\mathrm{N}$ deposition, and mass loss. Biogeochemistry, 60(1), 1-24.

Sinsabaugh R. L. (2008) Stoichiometry of soil enzyme activity at global scale Ecology Letters 11: $1252-1264$. 
Six, J., E.T. Elliott, K. Paustian, and J.W. Doran. 1998. Aggregation and soil organic matter accumulation in cultivated and native grassland soils. Soil Sci. Soc. Am. J. 62: 1367-1377.

Smock, L. A., \& MacGregor, C. M. (1988). Impact of the American chestnut blight on aquatic shredding macroinvertebrates. Journal of the North American Benthological Society, 212-221.

Taylor, M. K., Lankau, R. A., \& Wurzburger, N. (2016). Mycorrhizal associations of trees have different indirect effects on organic matter decomposition. Journal of Ecology, 104(6), 15761584 .

Vandermast, D. B. \&amp; Van Lear, D. H. (2002). Riparian vegetation in the southern Appalachian mountains (USA) following chestnut blight. Forest Ecology and Management, 155(1), 97-106.

Vesterdal, L., Elberling, B., Christiansen, J. R., Callesen, I., \& Schmidt, I. K. (2012). Soil respiration and rates of soil carbon turnover differ among six common European tree species. Forest Ecology and Management, 264, 185-196.

Wander, M. 2004. Soil organic matter fractions and their relevance to soil function. p. 67-102. In Magdoff , F., and R.R. Weil (ed.) Soil organic matter in sustainable agriculture. CRC Press, Boca Raton, FL.

Wang, G. G., Knapp, B. O., Clark, S. L., \& Mudder, B. T. (2013). The Silvics of Castanea dentata (Marsh.) Borkh. American Chestnut, Fagaceae (Beech Family). US Forest Service, Southern Research Station. General Technical Report SRS-173.

Wang, Q., Xiao, F., Zhang, F., \& Wang, S. (2013). Labile soil organic carbon and microbial activity in three subtropical plantations. Forestry, 86(5), 569-574.

Wardle, D.A., 1992. A comparative-assessment of factors which influence microbial biomass carbon and nitrogen levels in soil. Biolog. Rev. Cambridge Philos. Soc. 67, 321-358.

Yin, H., Wheeler, E., Phillips, R. P. (2014). Root-induced changes in nutrient cycling in forests depend on exudation rates. Soil Biology \& Biochemistry, 78, 213-221. 
Table 3.1: Significance factors of model effects and interactions for enzyme activity and ratios from soils collected from plots of chestnut, cherry and red oak and incubated for one year with leaf litter of their respective species.

\begin{tabular}{ccccc}
\hline Model Effect & AP & BG:NAG & PER & PPO \\
\hline Spacing & ns & $\mathbf{0 . 0 1 0 9}$ & $\mathbf{0 . 0 0 7 8}$ & $\mathbf{0 . 0 0 0 0 2}$ \\
Species & $\mathbf{0 . 0 0 4 5}$ & $<\mathbf{0 . 0 0 0 1}$ & ns & ns \\
Spacing x Species & $\mathbf{0 . 0 1 6 9}$ & ns & ns & ns \\
& & & & \\
ns = non-significant & & & & \\
& & & &
\end{tabular}


Table 3.2: Eigenvalues of two principal components (PC) of litter chemistry, soil chemistry, soil enzyme activity and all variables calculated using PCA, and significance of linear regression between PC's and litter decomposition rates from the incubation.

\begin{tabular}{lllll}
\hline Variable Type & PC & Eigenvalue & $\mathbf{R}^{\mathbf{2}}$ & p-value \\
\hline All & 1 & $31.3 \%$ & & \\
All & 2 & $21.4 \%$ & 0.3047 & $\mathrm{~ns}$ \\
Enzyme & 1 & $39.8 \%$ & 0.0041 & $\mathrm{~ns}$ \\
Enzyme & 2 & $24.5 \%$ & 0.0374 & $\mathrm{~ns}$ \\
Litter chemistry & 1 & $47.2 \%$ & 0.0028 & 0.0015 \\
Litter chemistry & 2 & $27.1 \%$ & 0.1835 & 0.0048 \\
Soil chemistry & 1 & $39.4 \%$ & 0.1481 & 0.0004 \\
Soil chemistry & 2 & $25.7 \%$ & 0.2157 & $\mathrm{~ns}$ \\
& & & 0.0316 & \\
& & & &
\end{tabular}




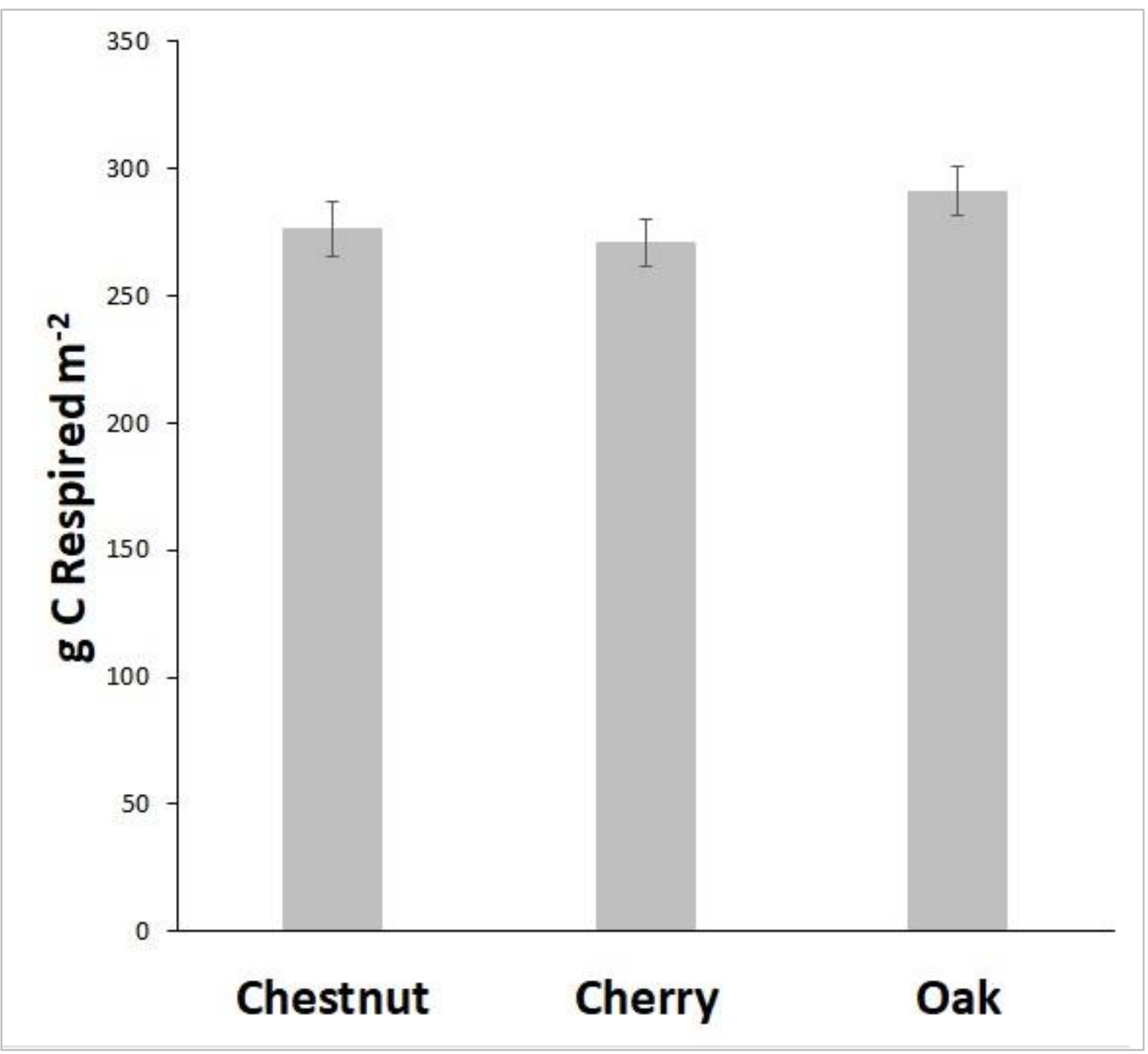

Figure 3.1: Mean cumulative $\mathrm{C}$ loss through respiration (+/- $1 \mathrm{SE})$ over $\mathrm{T}=10$ months of black cherry, American chestnut, and northern red oak. 


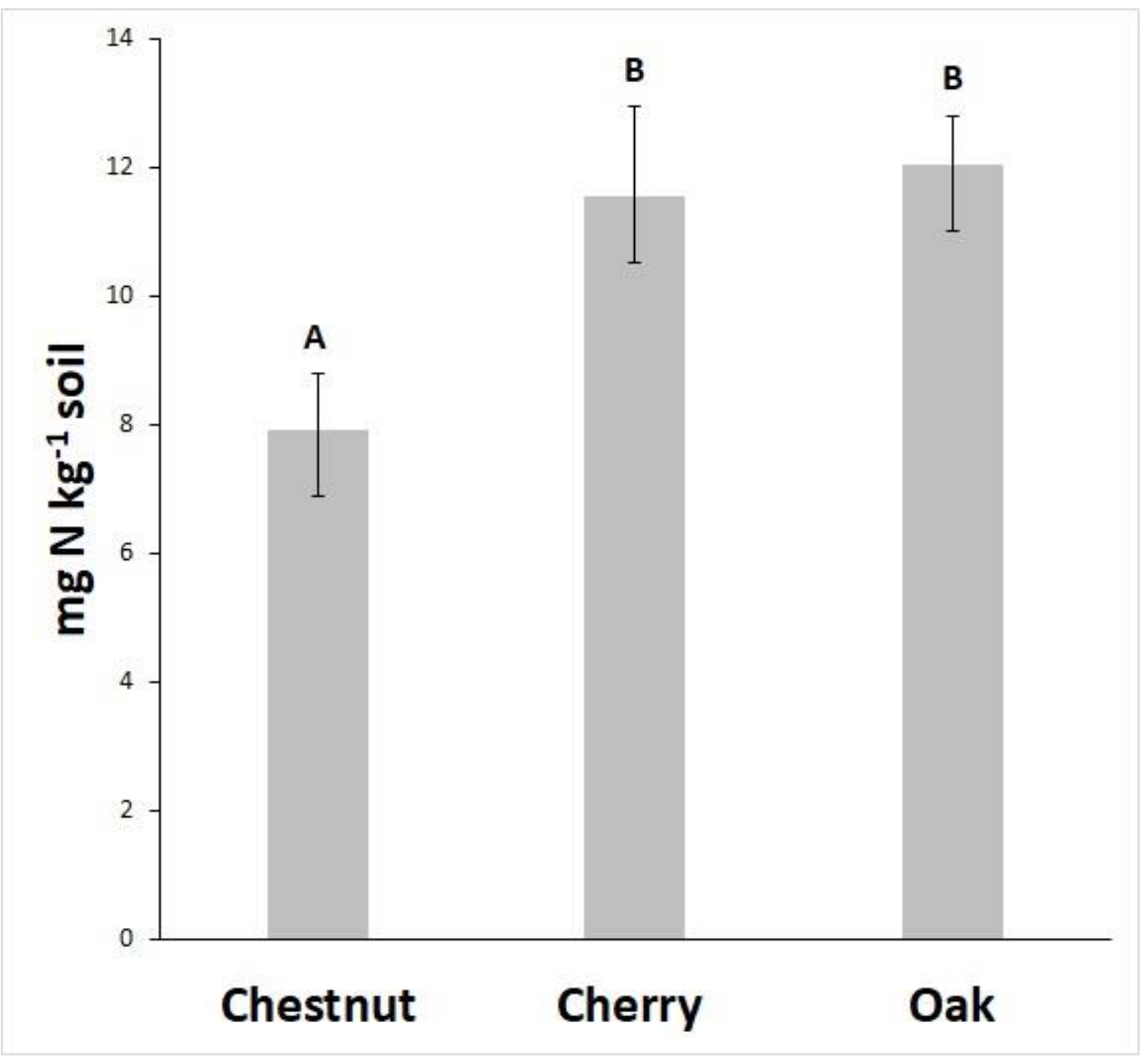

Figure 3.2: Mean cumulative $\mathrm{N}(+/-1 \mathrm{SE})$ mineralized over $\mathrm{T}=10$ months of American chestnut, black cherry and northern red oak. Bars with different letters are significantly different by Tukey HSD test. 


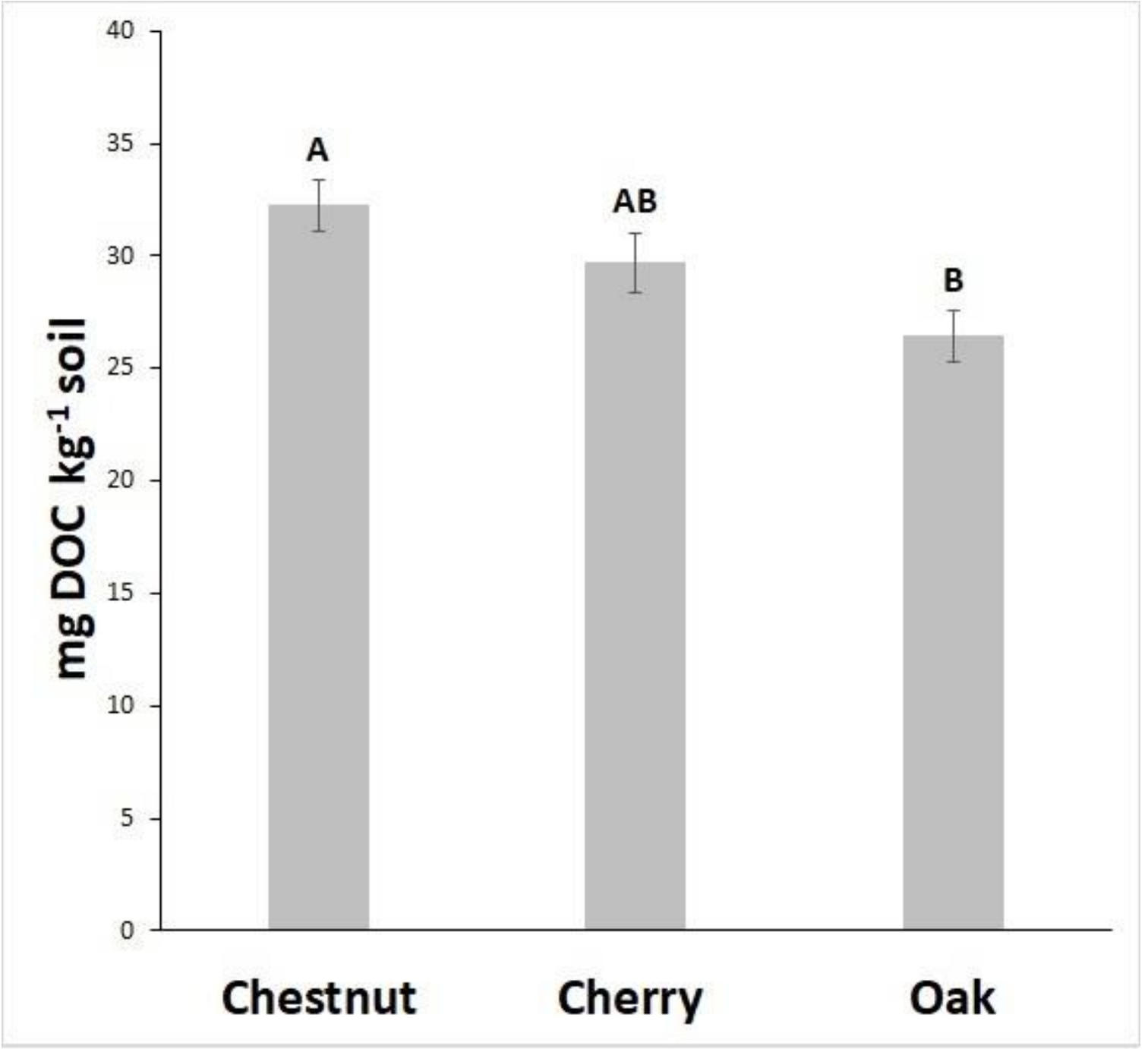

Figure 3.3: Mean cumulative DOC ( $+/-1 \mathrm{SE})$ collected over $\mathrm{T}=10$ months of American chestnut, black cherry and northern red oak. Bars with different letters are significantly different by Tukey HSD test. 


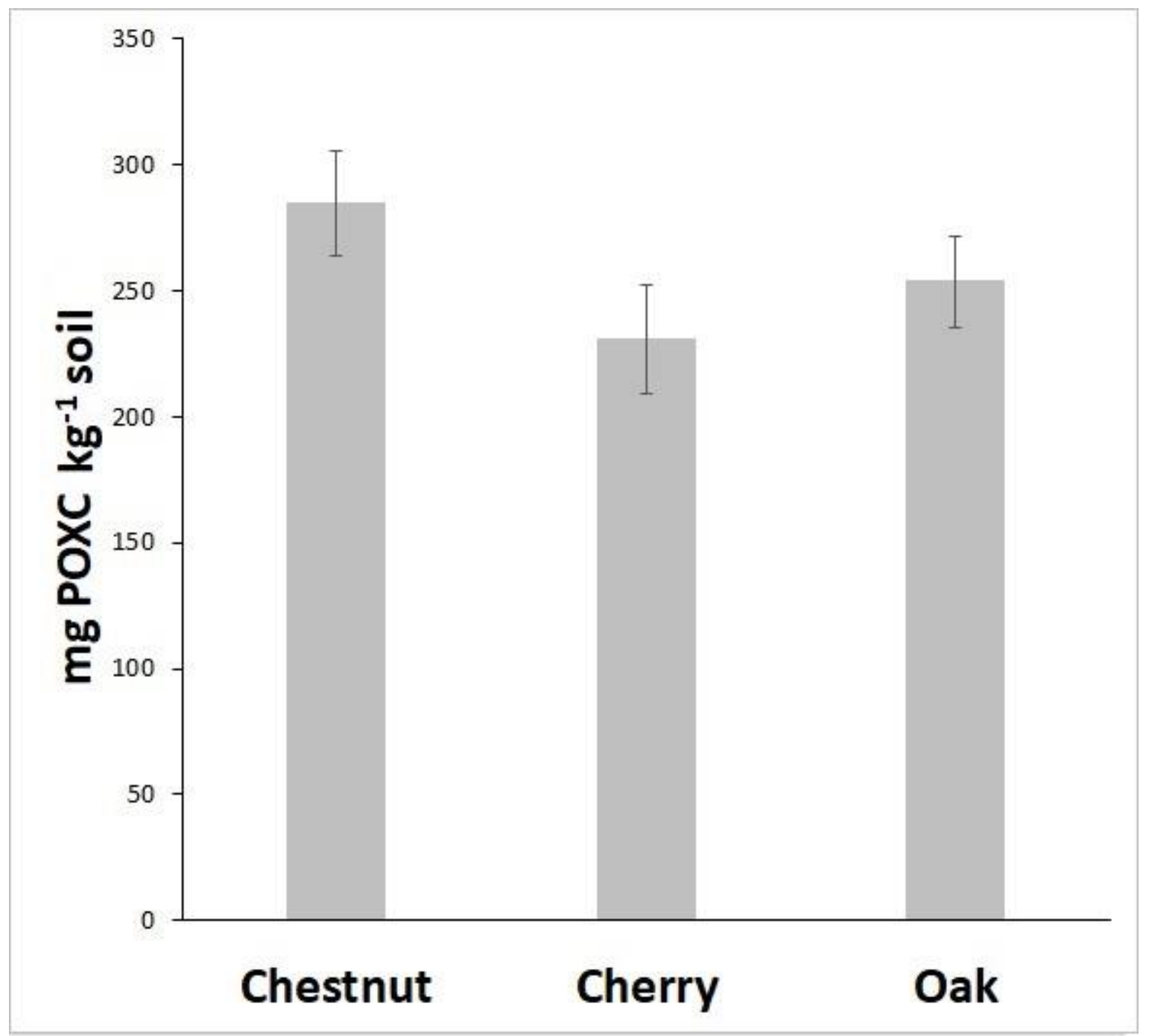

Figure 3.4: Mean total POXC (+/- $1 \mathrm{SE})$ by species, spacing and block. Error bars represent +/$1 \mathrm{SE}$ from the mean. 


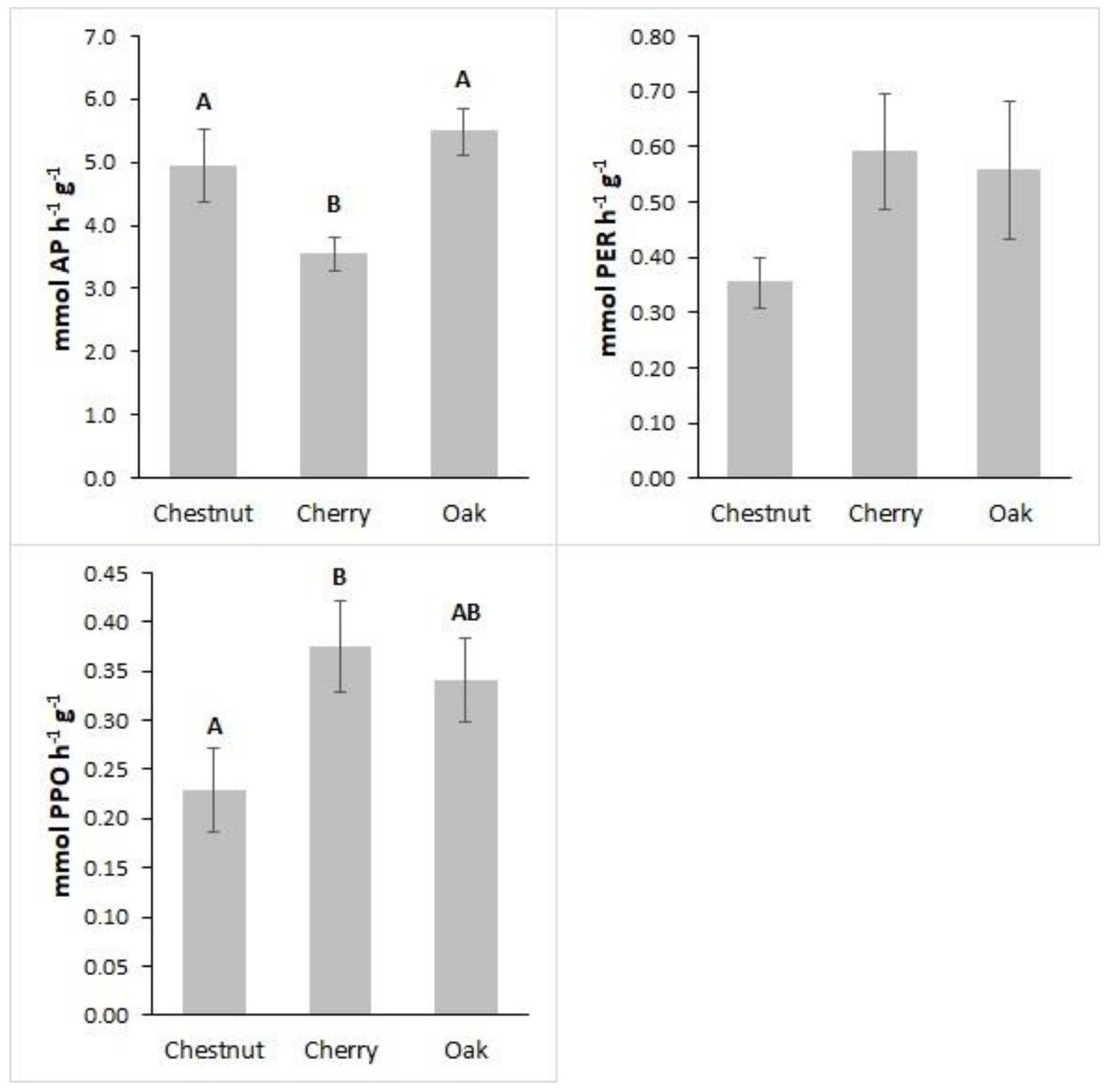

Figure 3.5: Mean enzyme activity $(\mathrm{mmol} / \mathrm{h} / \mathrm{g})(+/-1 \mathrm{SE})$ of AP (top left), PER (top right) and PPO (bottom left) for chestnut, black cherry and red oak. Bars with different letters are significantly different by Tukey HSD test. 


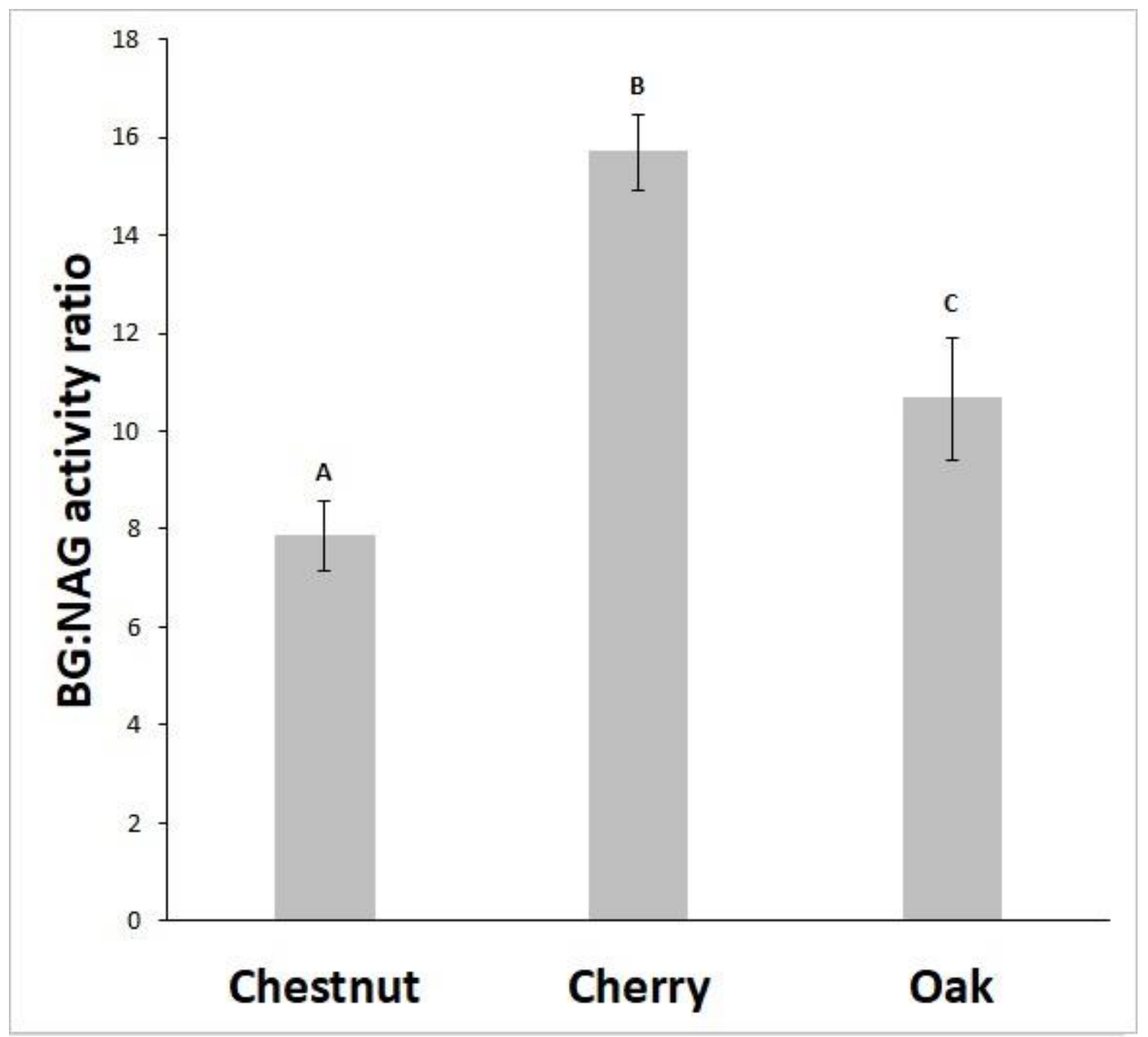

Figure 3.6: Mean (+/- 1 SE) BG:NAG enzyme activity ratio of soils from chestnut, cherry and oak incubation cores. Bars with different letters are significantly different by TukeyHSD test. 


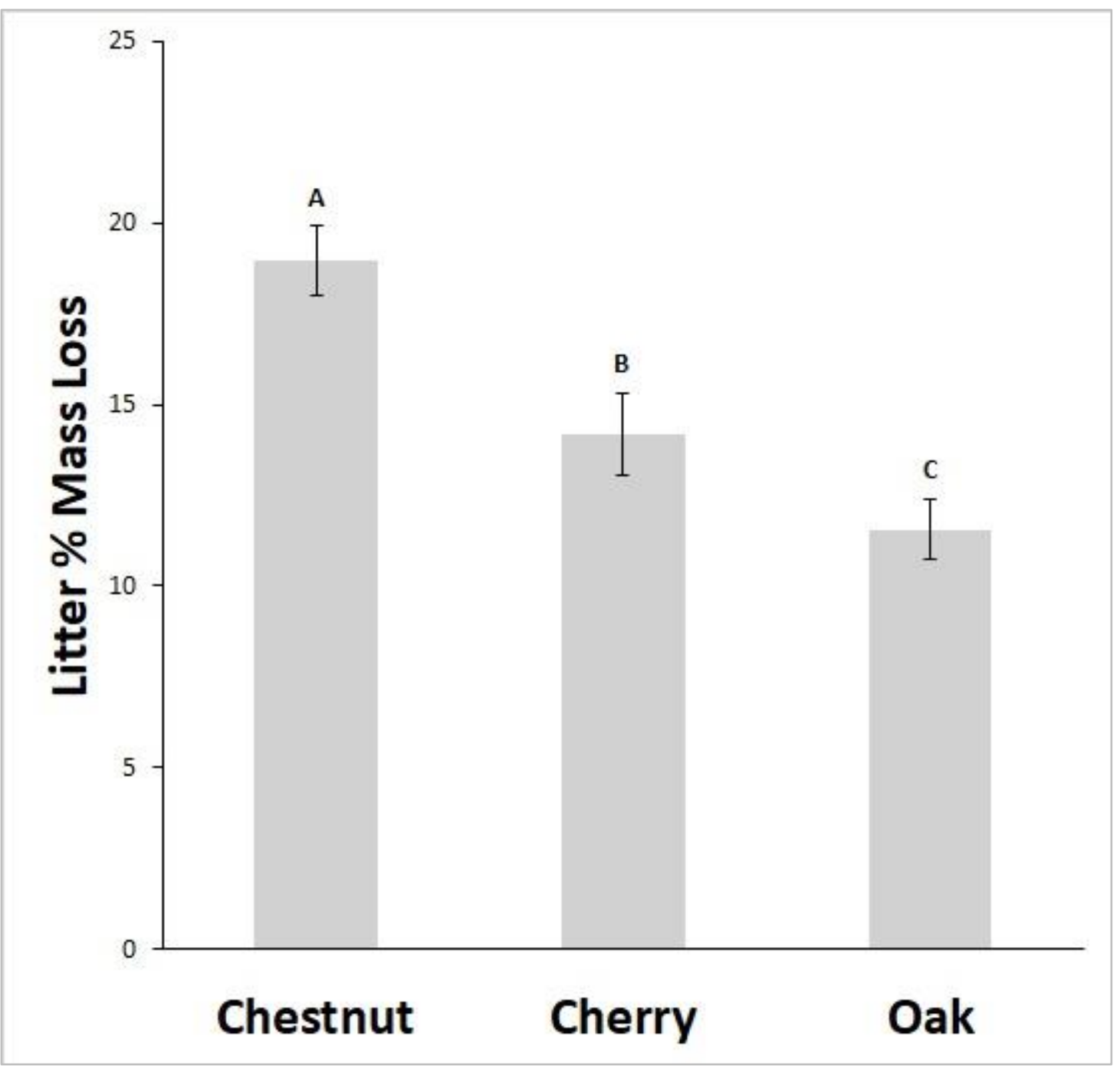

Figure 3.7: Mean $\%$ mass loss at $\mathrm{T}=1$ year of litter taken from chestnut, cherry and oak incubation cores. Bars with different letters are significantly different by TukeyHSD test. Error bars represent +/- $1 \mathrm{SE}$ from the mean. 


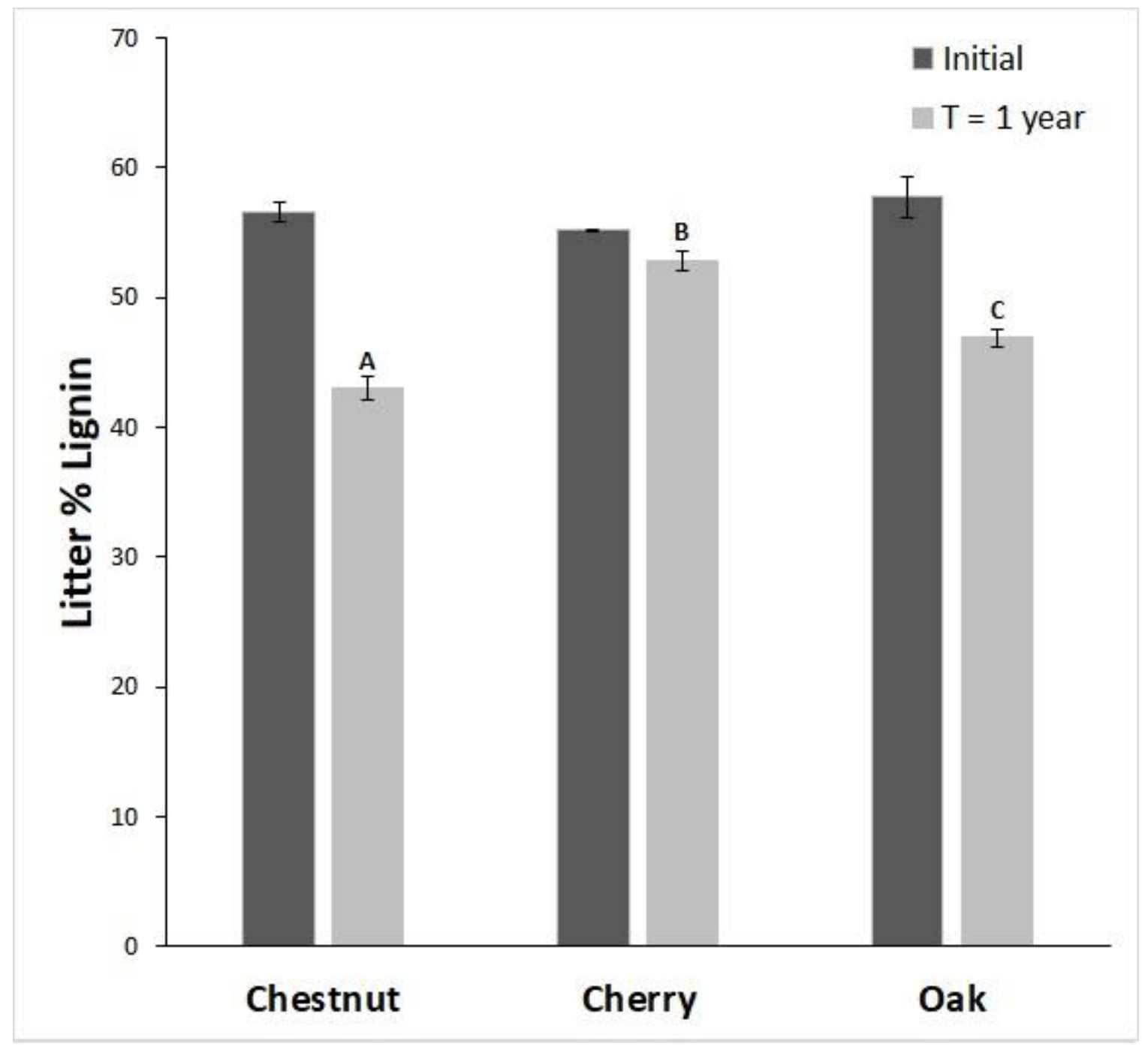

Figure 3.8: Acid insoluble compound and soluble lignin concentration of composited ( $\mathrm{n}=2$ per species) fresh litter from before incubation, and decayed litter at $\mathrm{T}=1$ year from chestnut, oak and cherry incubation cores. Bars with different letters are significantly different by Tukey HSD test. Error bars represent $+/-1 \mathrm{SE}$ from the mean. 


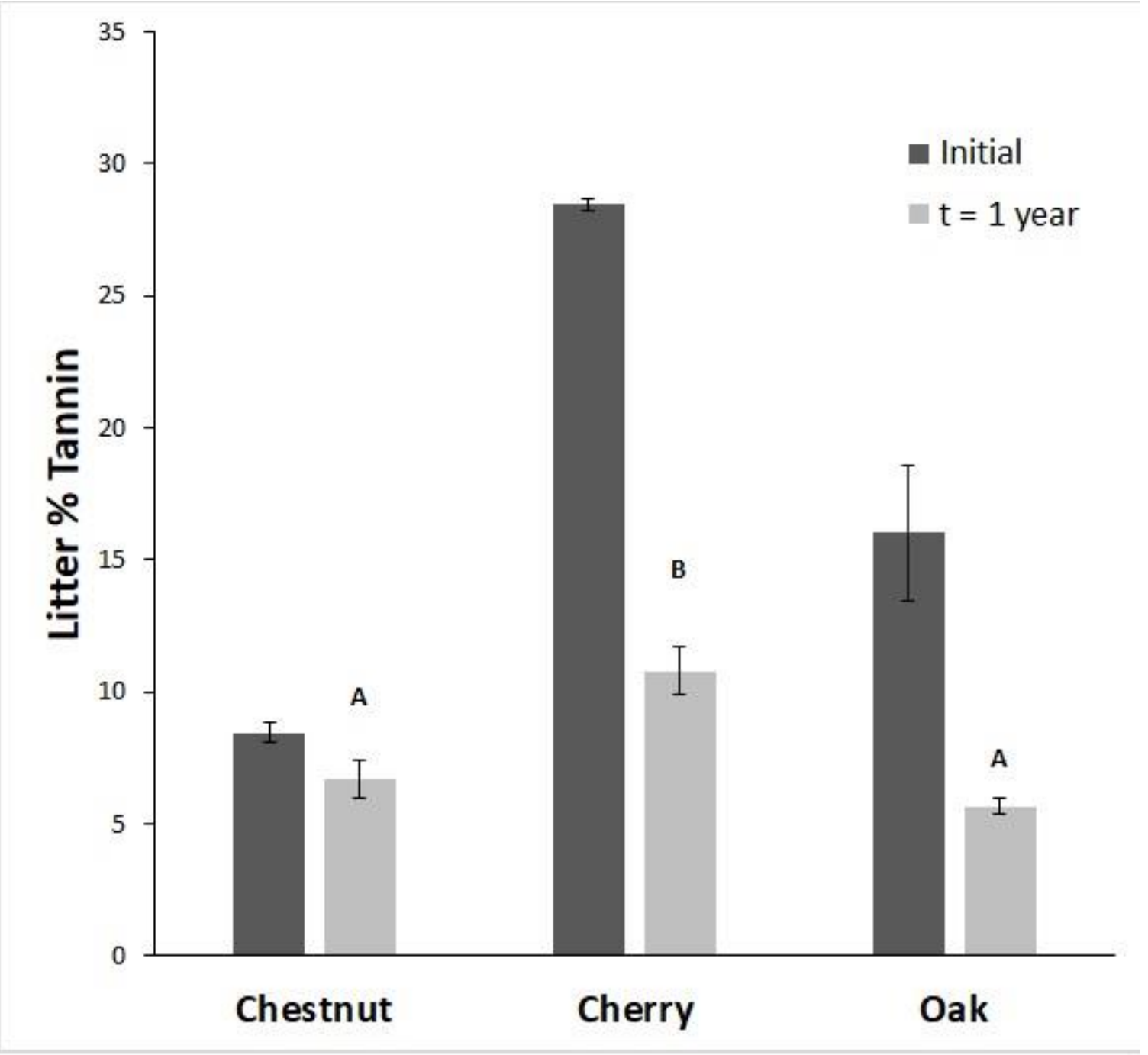

Figure 3.9: Tannin concentration of composited ( $n=2$ per species) fresh litter from before incubation, and decayed litter at $\mathrm{T}=1$ year from chestnut, oak and cherry incubation cores. Bars with different letters are significantly different by Tukey HSD test. Error bars represent +/- 1 SE from the mean. 


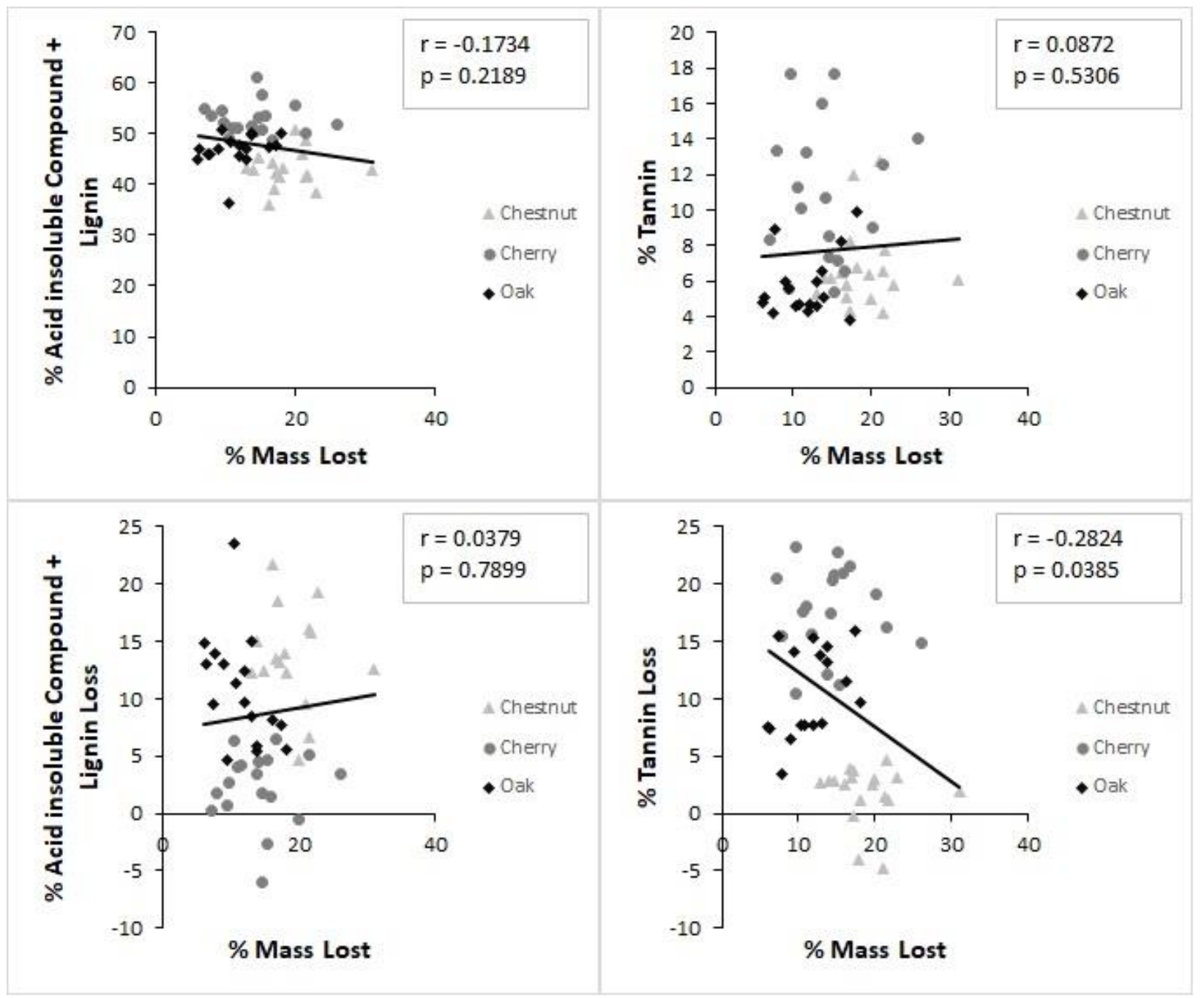

Figure 3.10: Correlations of $\%$ litter mass loss and litter $\%$ acid insoluble compounds and lignin (top left), \% tannin (top right), \% insoluble compound and lignin loss (bottom left) and \% tannin loss (bottom right). Correlation coefficient and $\mathrm{p}$ value are reported in the top right of each individual graph. 


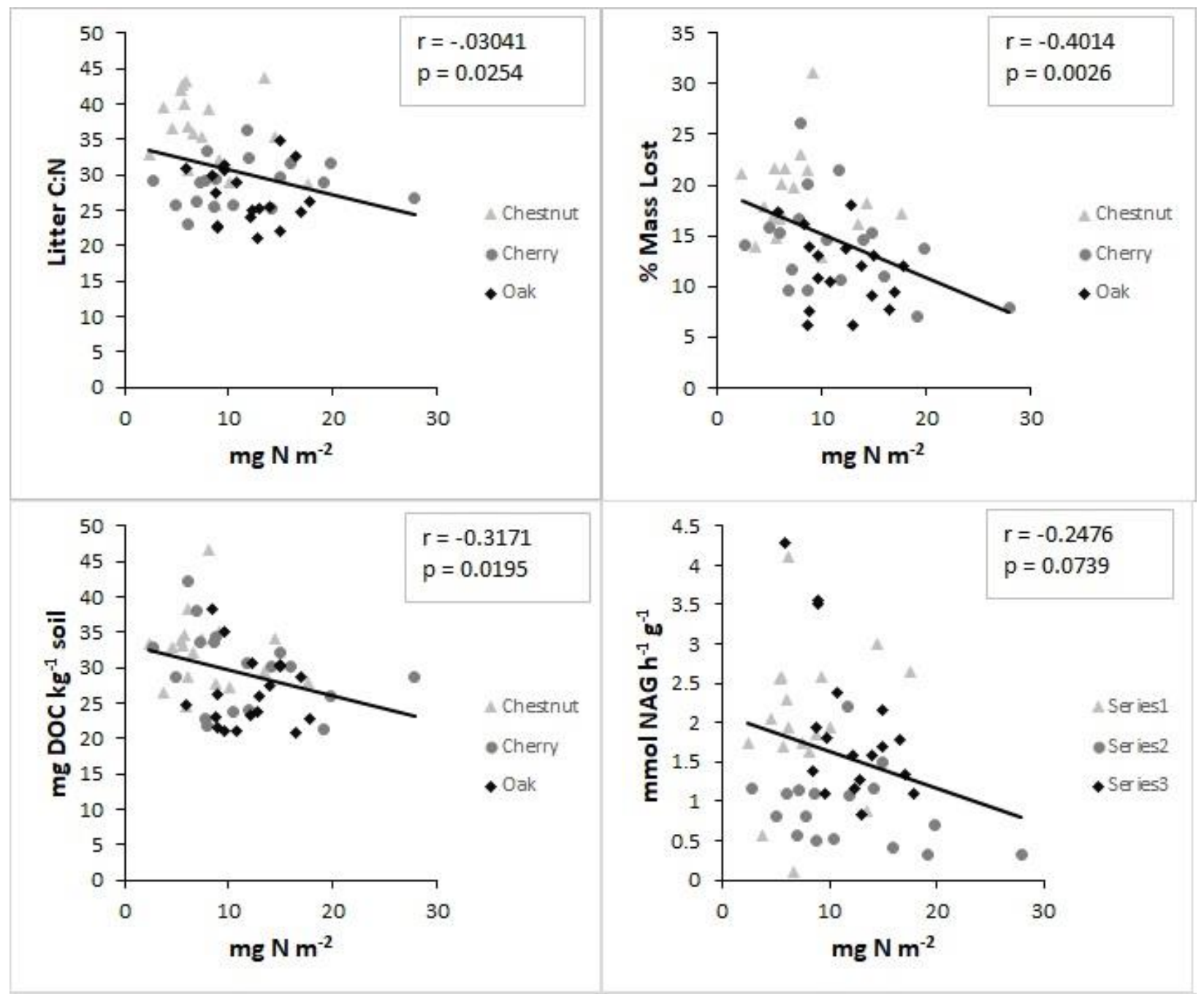

Figure 3.11: Correlations of $\mathrm{N}$ mineralized during incubation experiment and NAG enzyme activity (top left), \% litter mass loss (top right), DOC (bottom left) and \% tannin loss (bottom right). Correlation coefficient and $\mathrm{p}$ value are reported in the top right of each individual graph. 


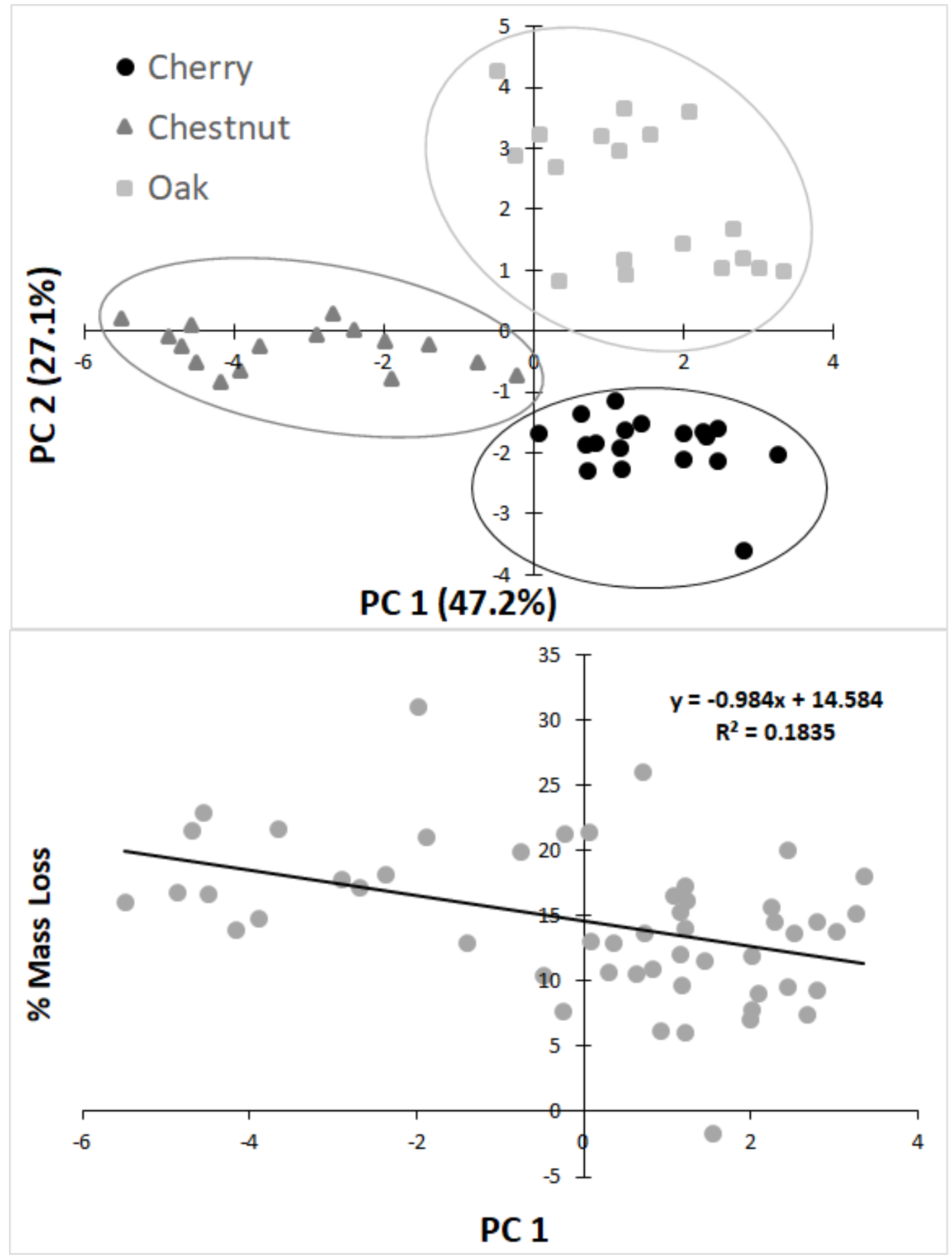

Figure 3.12: PCA of leaf litter chemistry variables, including species separation (top) and linear regression of litter decomposition against litter chemistry PC 1 (bottom). 